UNIVERSIDADE DE SÃO PAULO

ESCOLA DE ENGENHARIA DE LORENA

TAMIRES BREKAILO

ESTUDO DAS PROTRUSÕES NA RECRISTALIZAÇÃO DO NIÓBIO OLIGOCRISTALINO

LORENA 

TAMIRES BREKAILO

\section{ESTUDO DAS PROTRUSÕES NA RECRISTALIZAÇÃO DO NIÓBIO OLIGOCRISTALINO}

Tese apresentada à Escola de Engenharia de Lorena da Universidade de São Paulo para obtenção do título de Doutora em Ciências do Programa de Pós-Graduação em Engenharia de Materiais na Área de concentração: Materiais Metálicos, Cerâmicos e Poliméricos.

Orientador: Prof. Dr. Hugo R. Z. Sandim

Versão Corrigida

\section{LORENA}


AUTORIZO A REPRODUÇÃO E DIVULGAÇÃO TOTAL OU PARCIAL DESTE TRABALHO, POR QUALQUER MEIO CONVENCIONAL OU ELETRÔNICO, PARA FINS DE ESTUDO E PESQUISA, DESDE QUE CITADA A FONTE

Ficha catalográfica elaborada pelo Sistema Automatizado da Escola de Engenharia de Lorena,

com os dados fornecidos pelo(a) autor(a)

Brekailo, Tamires

Estudo das protrusões na recristalização do nióbio oligocristalino / Tamires Brekailo; orientador Hugo Ricardo Zschommler Sandim - Versão Corrigida. Lorena, 2019.

$119 \mathrm{p}$.

Tese (Doutorado em Ciências - Programa de Pós Graduação em Engenharia de Materiais na Área de Materiais Convencionais e Avançados) - Escola de Engenharia de Lorena da Universidade de São Paulo. 2019

1. Nióbio. 2. Oligocristais. 3. Recristalização. 4. Protrusões. I. Título. II. Sandim, Hugo Ricardo Zschommler, orient. 
As minhas avós,

Aparecida Maria Oliveira Siqueira

e

Jecy Matos Brekailo 



\section{AGRADECIMENTOS}

Ao Prof. Dr. Hugo Ricardo Zschommler Sandim pela orientação.

Ao Prof. Dr.-Ing. Dierk Raabe do Max-Planck-Institut für Eisenforschung (MPIF), pela disponibilização dos equipamentos para as medidas de EBSD e para as imagens de microscopia eletrônica de varredura de alta resolução. A Dayong An e ao Prof. Dr. Stefan Zaefferer, também do MPIE, pela realização das medidas de EBSD em 3D e ajuda na interpretação dos resultados.

Ao Prof. Dr. Raúl E. Bolmaro, do Instituto de Física de Rosário (IFIR), pela recepção e supervisão no IFIR, à Dra. Martina Avalos e aos técnicos de laboratório Vanina Tartalini e Pablo Risso, pelo auxílio com as medidas de EBSD.

Ao técnico do Laboratório de Materialografia do DEMAR, Sergio Luiz de Oliveira, pelo auxílio na preparação das amostras.

À CAPES pela concessão da bolsa de doutorado.

Ao Programa de Pós-Graduação em Engenharia de Materiais (PPGEM) e à Escola de Engenharia de Lorena pelo suporte para a realização deste doutorado.

Aos meus colegas de Pós-Graduação, em especial Mariane Capellari Leite da Silva, Davison Ramos de Almeida Junior, Isnaldi Rodrigues de Souza Filho, Bianca Maria Rodrigues e Thomas Conte Machado. 

"Que nada nos defina, que nada nos sujeite. Que a liberdade seja a nossa própria substância, já que viver é ser livre." 



\section{RESUMO}

BREKAILO, T. Estudo das protrusões na recristalização do nióbio oligocristalino. 2019. 119p. Tese (Doutorado em Ciências) - Escola de Engenharia de Lorena, Universidade de São Paulo, Lorena, 2019.

O crescimento dos núcleos de recristalização em direção à matriz deformada geralmente não ocorre de forma isotrópica. Perturbações locais na velocidade de migração dos contornos levam ao surgimento de protrusões. Trata-se de um aspecto importante na recristalização, porém ainda pouco explorado na literatura, especialmente quanto ao entendimento de quais mecanismos microestruturais explicam sua formação. O objetivo desta Tese de Doutorado é estudar a formação das protrusões na recristalização do nióbio oligocristalino. Para tal, uma chapa de nióbio com grãos bastante grosseiros foi retirada da seção longitudinal de um lingote fundido por feixe eletrônico. Foram selecionados de forma aleatória cinco grãos (A, B, C, D e E) para se avaliar eventuais efeitos de orientação na formação de protrusões. A chapa foi laminada a frio com vários passes até $50 \%$ de redução de espessura. Na sequência, a chapa foi dividida em duas partes, sendo que na primeira foi dado prosseguimento na laminação até atingir $70 \%$ de redução de espessura, enquanto que a segunda sofreu rotação de $90^{\circ}$ em relação à direção de laminação inicial. As amostras foram recozidas entre 800 e $1200^{\circ} \mathrm{C}$ por $60 \mathrm{~min}$. O grão E LC recristalizou em todas temperaturas estudadas, e o LD nas temperaturas entre 1000 e $1200^{\circ} \mathrm{C}$. O grão A LC recristalizou em todas temperaturas, exceto em $1000^{\circ} \mathrm{C}$, e LD recristalizou apenas em $1200^{\circ} \mathrm{C}$. O grão C LC recristalizou apenas em $1200^{\circ} \mathrm{C}$. Os grãos B e D não recristalizaram em nenhuma temperatura. Não foi possível identificar e associar diferenças significativas quanto ao potencial termodinâmico para recristalização à frente dos contornos com a formação das protrusões. Medidas de EBSD em 3D obtidas por seccionamento serial mostraram diferenças importantes do ponto de vista energético entre o contorno formado entre a protrusão e a matriz recuperada e o contorno entre a lateral do grão recristalizado e a matriz recuperada. O primeiro par é mais móvel, o que explica a morfologia alongada das protrusões.

Palavras-chave: Nióbio. Oligocristais. Recristalização. Protrusões. 


\begin{abstract}
BREKAILO, T. Study of protrusions on recrystallization of a niobium oligocrystal. 2019. 119p. Thesis (Doctoral of Science) - Escola de Engenharia de Lorena, Universidade de São Paulo, Lorena, 2019.
\end{abstract}

The growth of recrystallization nuclei towards the deformed matrix generally does not occur in an isotropic manner. Local disturbances in the migration along grain boundaries lead to the formation of protrusions. This is an important aspect in recrystallization, but still less explored in the literature, especially regarding the understanding of which microstructural mechanisms explain its formation. This Thesis aims at to study the formation of protrusions during recrystallization of a niobium oligocrystal. A coarse-grained niobium plate was cut out from the longitudinal section of an electron-beam cast ingot. Five coarse grains $(A, B, C, D$ and $\mathrm{E}$ ) were randomly selected for this study to evaluate possible orientation effects on protrusion formation. The plate was cold rolled with several passes up to $50 \%$ thickness reduction. The sheet was cut into two parts. The former was straight rolled until $70 \%$ thickness reduction while the latter was rotated $90^{\circ}$ with respect to the initial rolling direction. The samples were annealed at 800 to $1200^{\circ} \mathrm{C}$ for $60 \mathrm{~min}$. Grain E CR recrystallized at all temperatures studied, and SR at temperatures between 1000 and $1200^{\circ} \mathrm{C}$. Grain A CR recrystallized at all temperatures except $1000^{\circ} \mathrm{C}$, and SR recrystallized only at $1200^{\circ} \mathrm{C}$. Grain C CR recrystallized only at $1200^{\circ} \mathrm{C}$. Grains B and D did not recrystallize at any temperature. It was not possible to identify and to associate significant differences of the thermodynamic potential for recrystallization ahead of the boundaries with the formation of protrusions. 3D EBSD measurements obtained by serial sectioning showed important differences regarding grain boundary energy between the boundary formed between the protrusion and the recovered matrix and the boundary formed by the lateral part of the recrystallized grain and the recovered matrix. The first pair is more mobile, which explains the elongated morphology of the protrusions.

Keywords: Niobium. Oligocrystals. Recrystallization. Protrusions. 


\section{LISTA DE FIGURAS}

Figura 3.1 - Tântalo forjado rotativamente a frio com 99\% de redução em área. Seção longitudinal. MEV, elétrons retroespalhados.

Figura 3.2 - Detalhe da nucleação preferencial numa amostra de nióbio numa banda de deformação de um grão laminado até $70 \%$ de redução de espessura após recozimento em $800^{\circ} \mathrm{C}$ por $1 \mathrm{~h}$. A barra de escala é igual para as duas imagens.

Figura 3.3 - Variação da velocidade de migração do contorno de grão em função da diferença de orientação para alumínio em relação à direção <111>: (a) [27]; (b) [26].

Figura 3.4 - (a) Velocidade de migração de contornos de grão no chumbo a $300^{\circ} \mathrm{C}$ em função da concentração de estanho, para contornos de grão aleatórios e para contornos especiais; (b) o efeito do estanho na energia de ativação para a migração dos contornos de grãos aleatórios e para contornos especiais. 30

Figura 3.5 - Protrusões na recristalização estática em alumínio de alta pureza (MO).

Figura 3.6 - Protrusões na recristalização estática em uma amostra de nióbio de alta pureza (MO). 32

Figura 3.7 - Representação da reconstrução da expansão de um núcleo de recristalização usando a denominada microscopia em 4D. As letras de $A$ até I indicam a sequência de captura das imagens com o tempo .33

Figura 3.8 - Arranjo de discordâncias próximo ao contorno de grão em migração: (a) contorno plano; (b) contorno circular; (c) empilhamento de discordâncias em um contorno originalmente plano.

Figura 3.9 - Simulação da migração dos contornos de alto ângulo durante a recristalização: (a) Representação da variação de energia utilizando uma escala de cor, onde o preto representa a densidade de energia mais alta e branco uma densidade de energia igual a zero, para o espaçamento de 1,66 $\mu \mathrm{m}$; (b) posições dos contornos de grão em função do tempo, movimentação do contorno de baixo pra cima; (c) posições dos contornos de grão em função do tempo, movimentação do contorno da esquerda para a direita.

Figura 3.10 - Simulação da migração dos contornos de alto ângulo durante a recristalização: (a) Representação da variação de energia utilizando uma escala de 
cor, onde o preto representa a densidade de energia mais alta e branco uma densidade de energia igual a zero, para o espaçamento de 6,18 $\mu \mathrm{m}$; (b) posições dos contornos de grão em função do tempo, movimentação do contorno de baixo pra cima; (c) posições dos contornos de grão em função do tempo, movimentação do contorno da esquerda para a direita. 38

Figura 3.11 - Movimentação do contorno durante a recristalização: (a) Imagem de ECCI, onde a seta preta indica uma protrusão, e a branca uma retrusão; (b) mapeamento de EBSD; (c) indicação das posições do contorno de grão recristalizado durante o recozimento, intervalo de 500 s entre cada indicação. ... 39 Figura 3.12 - Tântalo deformado até $\varepsilon=1,3$ e recozido em $900^{\circ} \mathrm{C}$ por 30 min (MEV - elétrons retroespalhados), mostrando um contorno de alto angulo migrando em direção a uma área formada por subgrãos. 42 Figura 3.13 - Mapa de EBSD mostrando a microestrutura parcialmente recristalizada. 42 Figura 3.14 - Diferença na velocidade de migração entre dois grãos praticamente da mesma orientação e diferenças de orientação semelhantes em relação à matriz recuperada. Tempo de recozimento: (a) 7,5 $\mathrm{min}$; (b) 7,5 + 7,5 $\mathrm{min}$. 42 Figura 3.15 - Sessão de $\varphi_{2}=45^{\circ}$ de uma ODF mostrando as principais texturas para os materiais CCC: (a) localização das componentes de texturas mais importantes; (b) resultado experimental de um aço IF laminado a frio. 47 Figura 4.1 - Representação da chapa e dos eixos para a laminação direta e cruzada. 49

Figura 5.1 - Macroestrutura do material inicial: chapa de nióbio indicando os cinco grãos selecionados para o estudo (DL representa a direção que será adotada inicialmente na laminação). .53 Figura 5.2 - Mapeamentos de orientações, figuras de polo e orientação inicial dos grãos em estudo. 54 Figura 5.3 - Figuras de polo inversa mostrando a orientação dos grãos em relação à DL e DN. .55

Figura 5.4 - Macrografias evidenciando a variação na morfologia dos grãos nas chapas laminadas a frio até $70 \%$ de redução de espessura: (a) direta; (b) cruzada.

Figura 5.5 - Relação entre a microdureza Vickers e a deformação verdadeira para as amostras laminadas: (a) grão A; (b) grão B, C, D e E. 58 
Figura 5.6 - Micrografia mostrando a amostra E-LC (MEV-FEG), a DL final é paralela à barra de escala.

Figura 5.7 - Macrografia do A-LD evidenciando a estrutura fortemente bandeada.

Figura 5.8 - Mapeamento das orientações das amostras laminadas até 70\%: (a) ALD; (b) A-LC; (c) E-LD; (d) E-LC. 62

Figura 5.9 - Figuras de polo dos grãos A e E laminados até 70\%. Os pontos cinzas correspondem a amostra na condição inicial.

Figura 5.10 - Mapeamento dos contornos de grãos das amostras laminadas até 70\%: (a) A-LD; (b) E-LD; (c) E-LC.

Figura 5.11 - Histograma da desorientação no mapeamento das amostras laminadas até 70\%: (a) A-LD; (b) A-LC; (c) E-LD; (d) E-LC 65

Figura 5.12 - Gradiente de orientação $(\% / \mu \mathrm{m})$ representada na escala de intensidades em anexo: (a) A-LD; (b) A-LC; (c) E-LD; (d) E-LC............................66 Figura 5.13 - Histogramas dos gradientes de orientação: (a) A-LD; (b) A-LC; (c) ELD; (d) E-LC.

Figura 5.14 - Mapeamento da desorientação da matriz com os prováveis núcleos de recristalização das amostras laminadas até 70\% para as amostras: (a) A-LD; (b) E-LD; (c) E-LC

Figura 5.15 - Histograma da desorientação da matriz com os prováveis núcleos de recristalização das amostras laminadas até 70\% das amostras: (a) A-LD; (b) E-LD; (c) E-LC .70

Figura 5.16 - Visão geral da amostra E-LC recozida por $60 \mathrm{~min}$ em: (a) $800^{\circ} \mathrm{C}$; (b) $900^{\circ} \mathrm{C}$; (c) $1000^{\circ} \mathrm{C}$. DL final é paralela à barra de escala (MO). .73 Figura 5.17 - Micrografia da amostra A-LC-800 (MEV-FEG) sob diversas ampliações. .75

Figura 5.18 - Microscopia ótica (MO) da amostra E-LC-800 sob diversas ampliações. .76

Figura 5.19 - Detalhe de uma protrusão na amostra E-LC-800 (ECCI). Note a presença de facetas no contorno associado à protrusão e à subestrutura vizinha, indicadas pelas setas. .77

Figura 5.20 - Mapeamento das orientações da amostra E-LC-800: (a) visão geral da amostra; (b) detalhe de alguns grãos. Os contornos de baixo ângulo são 
marcados em branco, os contornos de alto ângulo em preto e os contornos especiais tipo CSL em vermelho.

Figura 5.21 - Figura de polo da amostra E-LC-800: (a) matriz recuperada; (b) grãos recristalizados. 80

Figura 5.22 - Microscopia ótica (MO) da amostra A-LC-900 sob diversas ampliações.

Figura 5.23 - Microscopia ótica (MO) da amostra E-LC-900, diversas ampliações. 82

Figura 5.24 - Mapeamento das orientações da amostra E-LC-900. 83 Figura 5.25 - Microscopia ótica (MO) da amostra E-LC-1000 sob diversas ampliações. .85

Figura 5.26 - Mapeamentos de orientação da amostra E-LC-1000 feitos em diferentes regiões da amostra. 86

Figura 5.27 - Mapeamentos de orientação da amostra E-LC-1000 em diferentes regiões da amostra com maiores ampliações.

Figura 5.28 - Detalhes dos mapeamentos de orientação da amostra E-LC-1000. 88

Figura 5.29 - Microscopia ótica (MO) da amostra E-LD-1000 sob diversas ampliações. 89

Figura 5.30 - Mapeamentos de orientação da amostra E-LD-1000 em diferentes regiões da amostra. 91

Figura 5.31 - Detalhes do mapeamento de orientações via EBSD da amostra ELD-1000. 92

Figura 5.32 - Microscopia ótica (MO) da amostra A-LC-1100 sob diversas ampliações. 93

Figura 5.33 - Microscopia ótica (MO) da amostra E-LC-1100 sob diversas ampliações. 94

Figura 5.34 - Microscopia ótica (MO) da amostra E-LD-1100 sob diversas ampliações 94

Figura 5.35 - Microscopia ótica (MO) da amostra A-LC-1200 sob diversas ampliações. 95

Figura 5.36 - Microscopia ótica (MO) da amostra C-LC-1200 sob diversas ampliações. 96 
Figura 5.37 - Microscopia ótica (MO) da amostra E-LC-1200. DL final, após rotação de $90^{\circ}$, é paralela à barra de escala.

Figura 5.38 - Mapeamento de orientação via EBSD da amostra A-LC-1200: (a) mapeamento de orientações; (b) figuras de polo discretas; (c) distribuição de desorientações 98

Figura 5.39 - Mapeamento de orientação via EBSD da amostra C-LC-1200: (a) mapeamento de orientações; (b) figuras de polo discretas; (c) distribuição de desorientações. 99

Figura 5.40 - Mapeamento de orientação via EBSD da amostra E-LC-1200: (a) mapeamento de orientações; (b) figuras de polo discretas; (c) distribuição de desorientações.

Figura 5.41 - Amostra E-LC-800: (a) micrografia da amostra (ECCI); (b) mapeamento de orientações; (c) figura de polo $\{001\}$ da área mapeada. 102 Figura 5.42 - Região selecionada para reconstrução em 3D: (a) mapa de KAM; (b) mapa de Ql das regiões selecionadas para reconstrução 3D; (c) perfil de desorientação ponto-a-ponto ao longo da DL final; (d) perfil de desorientação pontoa-ponto ao longo da DL inicial. Os contornos de alto ângulo são indicados em vermelho em (a) e (b). Os contornos de baixo ângulo são indicados em azul e verde, para desorientação entre $5^{\circ}$ e $15^{\circ}$, e abaixo de $5^{\circ}$, respectivamente. 102 Figura 5.43 - (a) reconstrução 3D do volume medido exibido pelo mapeamento de orientações com a DN como direção de referência; (b) reconstrução 3D de locais que contém a ponta de uma protrusão; (c) morfologia 3D da ponta da protrusão. A cor indica a direção normal do contorno de grão de acordo com a escala de cores. Os contornos de grão são gradeados em triângulos de superfície; (d) mostra a distribuição normal do plano dos contornos de grãos desses triângulos do mapeamento de orientações. N: o número de contornos de grãos total normal (igual à quantidade de triângulos de superfície em malha) 103 Figura 5.44 - (a) morfologia 3D do grão P1; (b) morfologia 3D dos contornos de grão entre matriz e o grão P1; (c) distribuição do contorno de grão; (d) morfologia 3D do grão P2; (e) morfologia 3D dos contornos de grão entre matriz e o grão P2; (f) distribuição do contorno de grão; (g) morfologia 3D do grão P3; (b) morfologia 3D dos contornos de grão entre matriz e o grão P3; (c) distribuição do contorno de grão. Nas figuras (a), (b), (d), (e), (g) e (h) a cor indica a normal ao contorno tanto no grão recristalizado como na matriz recuperada segundo a escala de cor. N: o 
número total de contornos de grão normal (igual à quantidade de triângulos de superfície em malha).

Figura 5.45 - (a) primeira camada do mapa de EBSD em 3D; (b) e (c) listam a distribuição dos polos $\{013\}$ e $\{011\}$ para os grãos P1 e P2, respectivamente. Estas figuras de polo são plotadas com o auxílio de um software in house TOCA no MPIE. Todos os possíveis pares $\{013\} /\{011\}$ são destacados por círculos vermelhos com um ângulo de desvio de cerca de $10^{\circ}$. As linhas tracejadas pretas e azuis indicam o possível traço dos contornos de grão que formam os pares $\{013\} /\{134\} \ldots \ldots . . .107$ 


\section{LISTA DE SIGLAS}

CCC Cúbica de corpo centrado

CFC Cúbica de face centrada

CG Contorno de grão

CSL Coincidence site lattice

DEMAR Departamento de Engenharia de Materiais

DL Direção de laminação

DN Direção normal

DSC Differential scanning calorimetry

DT Direção transversal

EBSD Electron bakscatter diffraction

$\mathrm{ECCl} \quad$ Electron channeling contrast imaging

EDE Energia de defeito de empilhamento

FEA Fator de empacotamento atômico

FEG Field emission gun

FIB Focused ion beam

GOS Grain orientation spread

IF Interstitial-free

IFIR Instituto de Física de Rosário

IQ Image quality

KAM Kernel average misorientation

MEV Microscopia eletrônica de varredura

MO Microscopia ótica

MPIE Max-Planck-Institut für Eisenforschung

MRD Multiples of the random distribution

ODF Orientation distribution function

OIM Orientation imaging microscopy

RV Recuperado

RX Recristalizado 



\section{SUMÁRIO}

1 INTRODUÇÃO 21

2 OBJETIVOS E JUSTIFICATIVAS 22

3 REVISÃO DA LITERATURA 23

3.1 Nióbio 23

3.2 Deformação plástica 23

3.2.1 Evolução microestrutural durante a deformação 24

3.3 Recuperação e recristalização 26

3.3.1 Variação local do potencial para recristalização 30

3.4 EDSD em 3D 44

3.5 Textura em metais com estrutura CCC 45

4 MATERIAIS E MÉTODOS 48

$\begin{array}{ll}\text { 4.1 Material } & 48\end{array}$

4.2 Métodos experimentais 48

$\begin{array}{lll}4.2 .1 & \text { Laminação } & 48\end{array}$

4.2.2 Recozimentos isotérmicos $\quad 49$

4.3 Caracterização microestrutural $\quad 49$

4.3.1 Preparação metalográfica 49

4.3.2 Microscopia ótica e microscopia eletrônica de varredura 50

4.3.3 Difração de elétrons retroespalhados 50

$\begin{array}{lll}\text { 4.3.4 Dureza Vickers } & 51\end{array}$

5 RESULTADOS E DISCUSSÃO 52

5.1 Caracterização microestrutural do material no estado inicial 52

5.2 Caracterização do material laminado a frio 55

$\begin{array}{ll}5.3 \text { Caracterização do material recozido } & 71\end{array}$

5.3.1 Recozimento em $800^{\circ} \mathrm{C} \quad 74$

$\begin{array}{lll}\text { 5.3.2 Recozimento em } 900^{\circ} \mathrm{C} & 80\end{array}$

5.3.1 Recozimento em $1000^{\circ} \mathrm{C} \quad 83$

$\begin{array}{ll}\text { 5.3.2 Recozimento em } 1100^{\circ} \mathrm{C} & 93\end{array}$

5.3.3 Recozimento em $1200^{\circ} \mathrm{C} \quad 95$

$\begin{array}{ll}5.4 \text { EBSD em 3D } & 101\end{array}$

6 CONCLUSÕES 108

$\begin{array}{ll}\text { REFERÊNCIAS } & 110\end{array}$ 



\section{INTRODUÇÃO}

$\mathrm{Na}$ teoria clássica de recristalização, núcleos isentos de defeitos e circundados por pelo menos um segmento de contorno de alto ângulo crescem varrendo a microestrutura e eliminando os defeitos cristalinos. Assumindo um material de alta pureza e que a força motriz para a reação seja distribuída de forma homogênea, o crescimento facetado ocorreria já que o contorno de grão e a mobilidade são anisotrópicos. Entretanto, experimentos controlados têm revelado que em diversos materiais ocorre a formação de ondulações nos contornos dos grãos durante a recristalização.

A formação destas ondulações, muitas vezes de forma periódica e organizada, não é explicada pelas teorias clássicas existentes. Estas ondulações nos contornos são chamadas de protrusões. Os segmentos do contorno que ficam para trás são denominados retrusões. Ao término da recristalização, estruturas peculiares formadas por grãos alongados surgem, diferindo das clássicas microestruturas observadas em metais com grãos finos e equiaxiais após a recristalização.

Protrusões são estruturas transientes que tendem a "desaparecer" à medida que a recristalização se completa. Por essa razão, talvez, tenham sido tão pouco estudadas. Vários modelos foram propostos na literatura para explicar sua formação, a maior parte deles abordando variações locais na mobilidade e na distribuição da energia armazenada na deformação. Essas teorias são apresentadas e discutidas na "Revisão da Literatura". 


\section{OBJETIVOS E JUSTIFICATIVAS}

A escolha do nióbio para o estudo de formação de protrusões durante a recristalização se deu por diversos motivos. A formação de protrusões já havia sido observada no nióbio por outros membros do nosso grupo de pesquisa. A escolha do nióbio oligocristalino para este estudo não é casual. O material possui elevada pureza e tamanho de grão na casa de alguns centímetros, minimizando o número de fatores que influenciam a recristalização, em especial a redução ou eliminação das forças de arraste (soluto e partículas) e a concorrência local da nucleação de outros grãos vizinhos, permitindo que as protrusões possam surgir e se desenvolver na microestrutura. Na prática, trata-se, portanto, do estudo da recristalização no interior de um monocristal.

Esta Tese tem por objetivo investigar os efeitos da orientação inicial dos grãos e do modo de deformação (laminação direta ou cruzada) na recristalização do nióbio, com grãos grosseiros, durante a laminação a frio e posterior recozimento, com ênfase na formação de protrusões. Esta rota permite produzir microestruturas que favorecem o surgimento de protrusões com elevada razão de aspecto. Deste modo, é possível estudá-las em amostras parcialmente recristalizadas e com boa base estatística, já que podem ser encontradas em vários locais da microestrutura.

Técnicas avançadas de caracterização, tais como a difração de elétrons retroespalhados em $3 \mathrm{D}$ via seccionamento serial foram utilizadas para 0 entendimento deste fenômeno. Os resultados são confrontados com aqueles reportados na literatura com relação aos modelos existentes para a formação de protrusões. A presente Tese possui dois aspectos bastante originais quanto ao estudo de protrusões que precisam ser destacados:

a) A caracterização microestrutural detalhada permitiu entender a formação de protrusões em nióbio com grãos grosseiros e o papel do modo de deformação escolhido (laminação cruzada) na formação destas estruturas peculiares;

b) $\mathrm{O}$ mapeamento de EBSD em 3D das protrusões permitiu identificar a existência de uma vantagem energética na migração dos contornos formados entre a ponta das protrusões e a matriz recuperada, comparados com os contornos formados entre a lateral do grão recristalizado e a matriz recuperada. 


\section{REVISÃO DA LITERATURA}

\subsection{Nióbio}

O nióbio é um metal refratário bastante dúctil e possui estrutura cristalina cúbica de corpo centrado (CCC), massa específica de $8570 \mathrm{~kg} / \mathrm{m}^{3}$ e ponto de fusão de $2468^{\circ} \mathrm{C}$. Não apresenta alotropia, o que favorece o estudo da recristalização em amplos intervalos de temperatura, sem que ocorra qualquer transformação estrutural. Dentre os metais refratários, o nióbio é o que possui a menor massa específica e a melhor trabalhabilidade a frio, sendo também um dos mais abundantes nesta categoria $(1,2)$.

Dentre as suas aplicações mais tradicionais, estão a fabricação dos materiais supercondutores $\mathrm{NbTi}_{\text {e }} \mathrm{Nb}_{3} \mathrm{Sn}$ (3), materiais para implantes cirúrgicos e ortopédicos ( $\mathrm{Nb}-\mathrm{TiO}_{2}$, por exemplo) (2), produção de ligas-mãe e ferroligas ( $\mathrm{Fe}-\mathrm{Nb}$ e $\mathrm{Ni}-\mathrm{Nb}$ ) para adição em superligas à base de níquel e em aços especiais, amplamente utilizados nas indústrias automobilística e aeroespacial e na fabricação de tubos para gasodutos e oleodutos, além de outras aplicações diversas e em menor escala. Uma maior e mais bem detalhada revisão sobre a produção e aplicação do nióbio pode ser encontrada nas referências $(1,2)$.

\subsection{Deformação plástica}

A deformação plástica nos metais pode ocorrer por quatro mecanismos principais distintos: escorregamento das discordâncias, maclação, escorregamento de contornos (fluência em altas temperaturas) e transformações de fase com variação do volume, tal como na transformação martensítica $(4,5)$.

Três mudanças principais ocorrem durante a deformação plástica. A mudança da forma dos grãos acompanhada do aumento da quantidade da área dos contornos e pela formação da subestrutura de deformação à medida em que se subdividem pelo aumento do número de defeitos. Por fim, a textura cristalográfica é progressivamente alterada em consequência da rotação dos grãos para acomodar a deformação plástica e manter a compatibilidade da deformação entre os grãos $(1,3)$. 
Durante a deformação de metais e ligas a maior parte de energia é perdida na forma de calor e apenas cerca de $2 \%$ da energia é acumulada no material na forma de defeitos cristalinos, principalmente discordâncias (4-6). No escorregamento, as discordâncias interagem com outras discordâncias e outros defeitos, levando a sua multiplicação, reduzindo a sua mobilidade e formando estruturas mais complexas e de baixa energia $(4,7,8)$.

Deste modo, é importante entender e quantificar a microestrutura do estado deformado para compreender as alterações microestruturais que ocorrem posteriormente na recuperação e recristalização. Para isso, é necessário se determinar a densidade de discordâncias, mas também a forma na qual elas se rearranjam (formação de células e subgrãos) e quantificar as diferenças de orientação associadas. Portanto, no caso da recristalização e eventual formação de protrusões, mais importante que a magnitude da energia armazenada no material é saber a forma como ela se encontra distribuída no material $(4,6,9)$.

\subsubsection{Evolução microestrutural durante a deformação}

A evolução microestrutural de monocristais e policristais pode ser descrita pela subdivisão dos grãos e a formação de contornos de alto ângulo à medida que a deformação aumenta, formando estruturas hierárquicas cada vez mais finas à medida que a tensão e a deformação aplicada aumentam (6).

A deformação plástica, salvo poucas exceções, não ocorre de forma homogênea nos materiais metálicos, seja por fatores extrínsecos ou intrínsecos. Durante a deformação os grãos são subdivididos em regiões menores devido à formação de discordâncias, levando a formação das heterogeneidades de deformação (6,10-12). Elas são regiões que apresentam uma maior densidade de defeitos cristalinos, então é de grande importância o seu entendimento, pois como comentado anteriormente é necessário conhecer a distribuição de defeitos do material, pois a distribuição de energia armazenada é diferente $(5,9,11,13)$. As heterogeneidades originam-se no material devido às instabilidades que ocorrem durante a deformação plástica e ocorrem com maior frequência em materiais com grãos grosseiros, em especial as bandas de deformação e as de transição (14). Segundo o modelo de subdivisão dos grãos aplicado a metais com média e elevada energias de defeito de empilhamento (EDE) (12-14), a deformação plástica ocorre 
em duas escalas. Macroscopicamente, os grãos se subdividem mediante a formação de bandas de deformação e de transição. Microscopicamente, cada banda vai continuar a se subdividir pela geração e multiplicação de novas discordâncias, seguida da formação de células e subgrãos. Posteriormente estes contornos evoluem para a formação de microbandas e densas paredes de discordâncias à medida que a deformação aumenta, culminando com a formação de contornos lamelares alinhados paralelamente à direção de laminação $(11,12,14)$.

As principais heterogeneidades formadas são as bandas de deformação, de transição e de cisalhamento (shear bands) (5). Durante a deformação de metais com grãos grosseiros, cada grão se comporta de forma diferente dos seus vizinhos e as heterogeneidades formadas dependem das restrições impostas por eles. Estudos realizados em bicristais e tricristais de nióbio mostram que o grau de encruamento, a forma de subdivisão e a desorientação na substrutura variam de grão para grão, evidenciando a importância da orientação inicial $(15,16)$. A Figura 3.1 mostra a microestrutura de uma amostra de tântalo forjada rotativamente a frio com $99 \%$ de redução de área. Ela mostra a diferença da subdivisão em dois grãos vizinhos, onde o grão inferior subdividiu-se numa estrutura lamelar e o grão superior deformou-se de forma mais estável, sem a formação de subgrãos (17). Nos grãos que se deformam de forma estável, predominam apenas pequenas diferenças de orientação, sendo pouco propícios para a nucleação da recristalização. Por outro lado, nos grãos onde a subdivisão é mais intensa, maiores desorientações se desenvolvem e a recristalização ocorre de forma mais pronunciada (12).

A formação de estruturas de discordâncias complexas indica que diferentes sistemas de escorregamento combinados atuam no grão. Sendo assim, diferentes partes de um mesmo grão giram resultando em regiões com diferentes orientações dentro do mesmo grão (12). O modelo de subdivisão de grãos em metais que sofrem a formação de bandas requer a ativação de um número menor de sistemas de escorregamento simultâneos e independentes do que o preconizado pelo modelo de plasticidade de Taylor (pelo menos cinco sistemas de escorregamento simultâneos e independentes). O modelo de Taylor é aplicável a metais com grãos finos e equiaxiais, diferentemente do que ocorre no material estudado nesta Tese. Assim, uma menor tensão é necessária para que a deformação ocorra. Porém, a 
formação de bandas aumenta a energia total do sistema pela criação de novas interfaces, facilitando a posterior nucleação da recristalização $(18,19)$.

Figura 3.1 - Tântalo forjado rotativamente a frio com 99\% de redução em área. Seção longitudinal. MEV, elétrons retroespalhados.

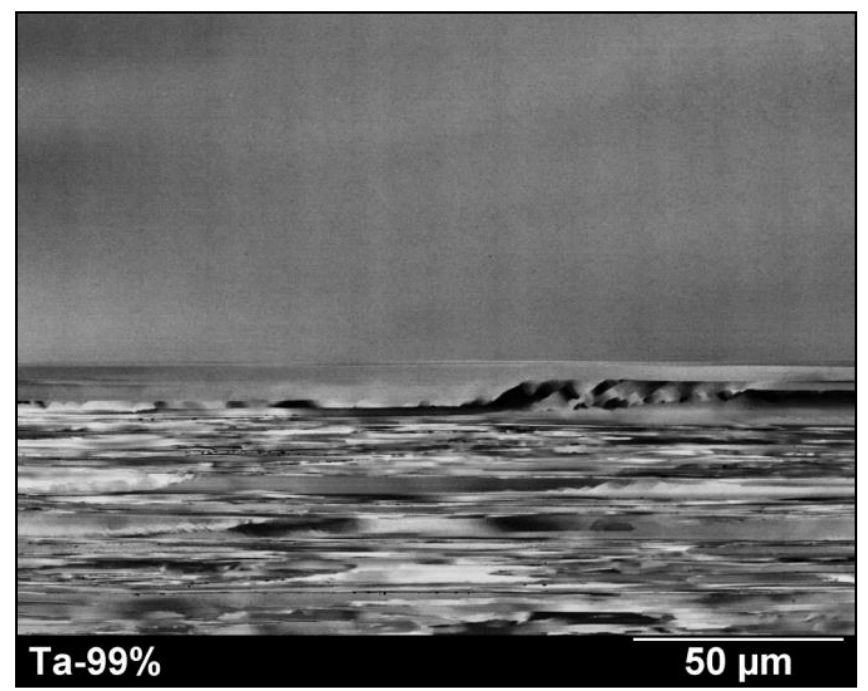

Fonte: (17).

\subsection{Recuperação e recristalização}

A energia armazenada no material durante a deformação é termodinamicamente instável, mas em temperatura ambiente os mecanismos difusionais necessários para a eliminação dos defeitos não ocorrem para a maioria dos materiais por razões cinéticas. Se o material for aquecido até uma temperatura elevada onde a difusão atômica se torna apreciável ( $T>0,4 \mathrm{~T}$, onde $T_{m}$ é o ponto de fusão do metal em Kelvin), haverá a aniquilação e o rearranjo dos defeitos para uma configuração de menor energia (4). Essa eliminação e rearranjo dos defeitos são a recuperação e recristalização, onde a recuperação é a eliminação de defeitos sem a movimentação de contornos de alto ângulo, enquanto que na recristalização ocorre a eliminação de defeitos com a movimentação de contornos de alto ângulo (5). Os defeitos acumulados e sua energia elástica associada durante a deformação plástica constituem o potencial termodinâmico para a ocorrência tanto da recuperação como da recristalização $(4-6,11)$.

A recuperação e a recristalização são reações no estado sólido concorrentes e às vezes simultâneas, pois ambas são movidas pela redução da energia armazenada do estado encruado. Logo, a extensão da recuperação 
depende da facilidade com que a recristalização ocorre, sendo que a temperatura de recozimento e a EDE são preponderantes para definir as faixas onde uma ou outra reação predomina (20).

A recristalização pode ser abordada como sendo uma pseudotransformação de fase e ocorre em duas etapas, simultâneas ou consecutivas, nucleação e crescimento $(4,13)$. A nucleação é a formação de uma região livre de defeitos associada a um contorno de alto ângulo apto a migrar ou pelo menos um segmento de contorno de alto ângulo. Na prática, considera-se que os núcleos de recristalização são regiões pré-existentes no estado deformado $(4,13)$. A etapa de crescimento é difusional e consiste na migração do contorno de alto ângulo varrendo a microestrutura $(21,22)$. A nucleação ocorre preferencialmente em locais de maior energia acumulada e desorientações na microestrutura, como contornos de grão, ao redor de partículas grosseiras e heterogeneidades de deformação $(4,5,21)$. Como o nióbio utilizado é de alta pureza e os grãos são grosseiros, a nucleação ocorre preferencialmente nas heterogeneidades de deformação. A Figura 3.2 mostra a nucleação numa banda de deformação numa amostra de nióbio laminado até $70 \%$ de redução de espessura e recozido em $800^{\circ} \mathrm{C}$ por $1 \mathrm{~h}$ (16).

Durante o crescimento (expansão dos núcleos) das regiões recristalizadas a velocidade de migração do contorno de alto ângulo em metais deformados, $v$ $(\mathrm{m} / \mathrm{s})$, depende da pressão-motriz, $P\left(\mathrm{~J} / \mathrm{m}^{3}\right)$, e da mobilidade do contorno, $M$ $\left(\mathrm{m}^{4} / \mathrm{J} . \mathrm{s}\right)$. Esses fatores se correlacionam conforme mostra a Equação $1(4,13,23)$ :

$$
v=M P
$$

A pressão-motriz $(P)$ é a resultante do somatório das forças motrizes e das forças retardadoras $(22,24)$. A mobilidade é o parâmetro cinético da reação, que relaciona a mobilidade intrínseca do contorno $\left(M_{0}\right)$ com a temperatura absoluta $(T)$ por uma relação do tipo Arrhenius, a qual é calculada com auxílio da Equação 2:

$$
M=M_{0} \exp \left(-\frac{Q}{R T}\right)
$$

onde, $Q$ é a energia de ativação para autodifusão e $R$ é a constante universal dos gases $(4,20)$. 
Figura 3.2 - Detalhe da nucleação preferencial numa amostra de nióbio numa banda de deformação de um grão laminado até $70 \%$ de redução de espessura após recozimento em $800^{\circ} \mathrm{C}$ por $1 \mathrm{~h}$. A barra de escala é igual para as duas imagens.
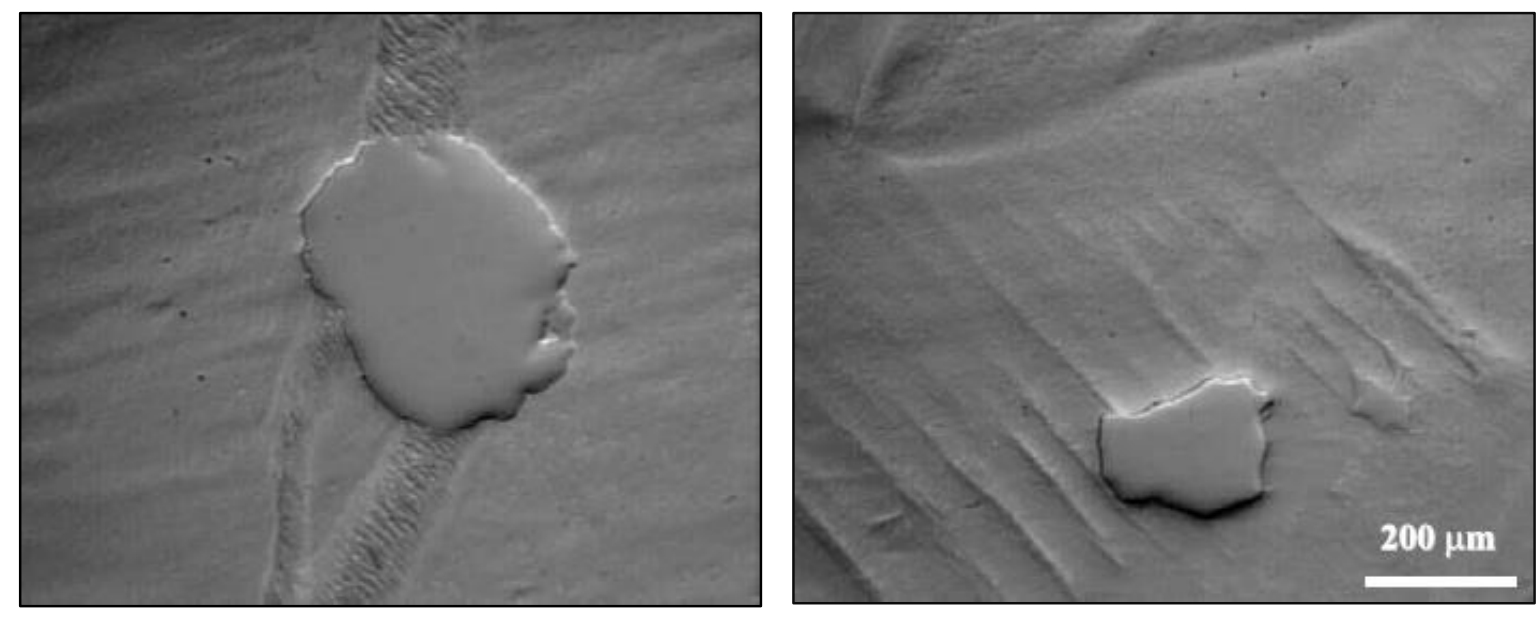

Fonte: (16).

A mobilidade do contorno não é uma propriedade totalmente conhecida ainda, pois a migração dos contornos ocorre em altas temperaturas e fora das condições de equilíbrio. Desta forma, observações experimentais in situ são bastante difíceis, especialmente nesta faixa de temperaturas $(4,23)$. Mesmo assim sabe-se de alguns fatores afetam a mobilidade dos contornos de grão, tais como a temperatura, a diferença de orientação entre dois grãos vizinhos, a natureza do contorno e a textura $(22,25)$. Então é de grande importância estudar a mobilidade dos contornos de grão, pois ela é a variável que controla a recristalização e o crescimento de grão e, por conseguinte, afeta a evolução da microestrutura e a formação da textura cristalográfica $(25,26)$.

Embora a Equação 1 não explicite qualquer influência da orientação cristalográfica, diferenças de orientação com relação a uma dada direção apresentadas pelos contornos de grão levam a intervalos distintos de mobilidade $(5,24)$. A diferença de orientação associada aos contornos tem grande influência na mobilidade. Em 1956, Liebman, Lücke e Masing reportaram esse efeito para o alumínio, como mostra a Figura 3.3 (a) (27), onde a máxima mobilidade ocorre para a desorientação de aproximadamente $40^{\circ}$. Mais tarde Huang e Humphreys mostram resultados compativeis utilizando deformações diferentes, sendo sempre a máxima mobilidade para a desorientação de aproximadamente $40^{\circ}<111>$, como mostra a Figura 3.3 (b) (26). 
Figura 3.3 - Variação da velocidade de migração do contorno de grão em função da diferença de orientação para alumínio em relação à direção <111>: (a) [27]; (b) [26].

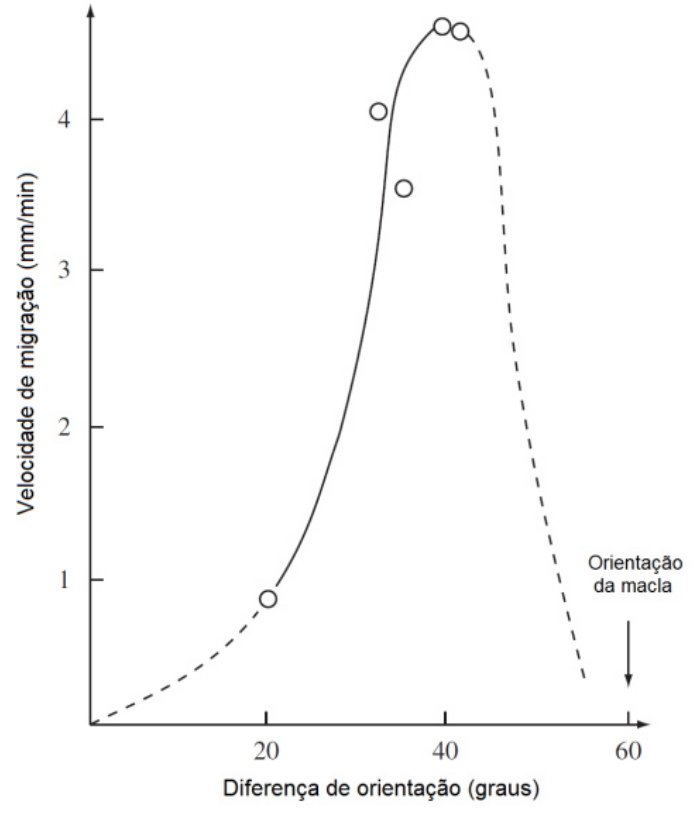

(a)

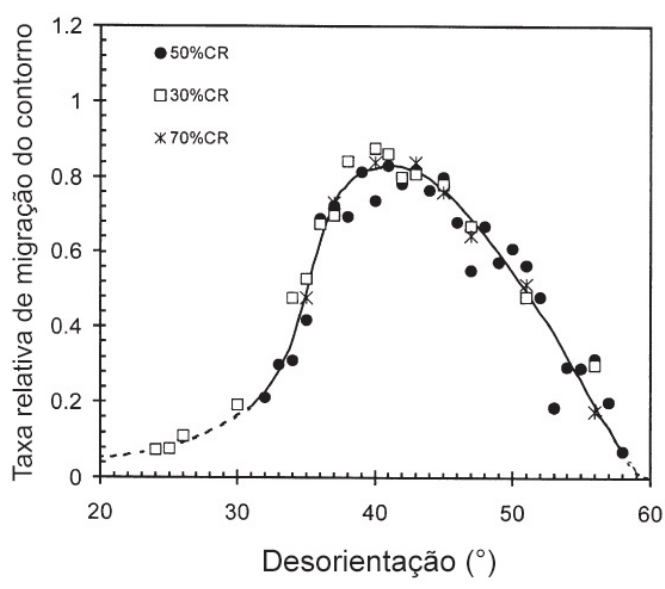

(b)

Fonte: Adaptado de (26) e (27).

Alguns contornos podem possuir uma desorientação especifica com o seu vizinho levando a uma alta densidade de sítios coincidentes, ou seja, uma fração de posições cristalográficas no reticulado é compartilhada pelos dois grãos vizinhos. Esses tipos de contornos são chamados de contornos especiais ou de contornos de alta coincidência (CSL, do inglês, coincidence site lattice). Esse tipo de relação de orientação especial confere algumas propriedades especiais para os contornos, por exemplo, o contorno coerente de macla do tipo $\Sigma 3$ que é de baixa energia e baixa mobilidade, enquanto que o contorno $\Sigma 7$ apresenta alta mobilidade para metais com estrutura cúbica de face centrada (CFC) $(4,28,29)$.

A Figura 3.4 mostra a diferença dos contornos especiais para os contornos aleatórios para o chumbo, também com estrutura CFC. A Figura 3.4 (a) mostra a diferença na velocidade de migração dos contornos, comparando alguns contornos especiais com os aleatórios e também a influência de pequenas adições de estanho, onde os contornos especiais apresentam uma maior velocidade que os demais. A Figura 3.4 (b) mostra que os contornos especiais necessitam de uma menor energia de ativação para migrar $(30,31)$. 
Figura 3.4 - (a) Velocidade de migração de contornos de grão no chumbo a $300^{\circ} \mathrm{C}$ em função da concentração de estanho, para contornos de grão aleatórios e para contornos especiais; (b) o efeito do estanho na energia de ativação para a migração dos contornos de grãos aleatórios e para contornos especiais.

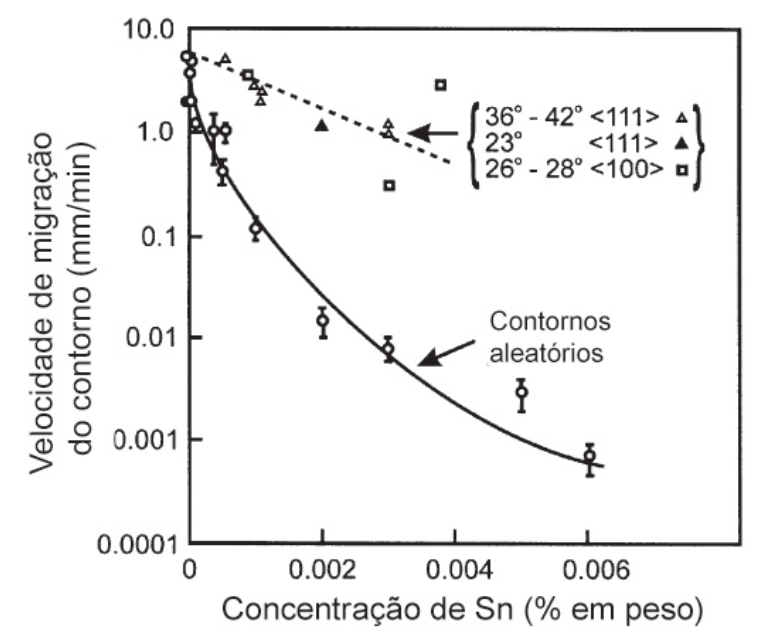

(a)

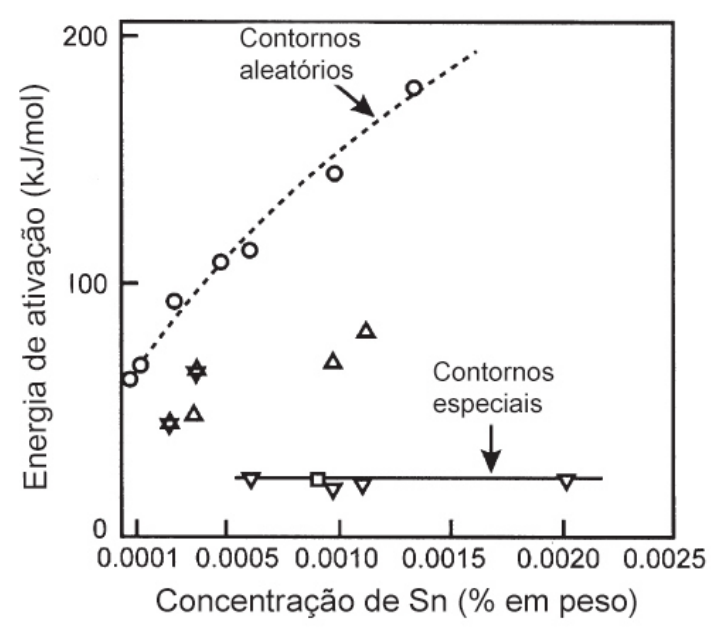

(b)

Fonte: Adaptado de (30) e (31).

\subsubsection{Variação local do potencial para recristalização}

Variações na natureza do estado deformado, podem levar a diferenças significativas na velocidade de recristalização no material. Estas variações podem ter origem nas heterogeneidades de deformação, causando diferentes quantidades de energia armazenada em cada região do material, pois a deformação da microestrutura (arranjo de discordâncias) na frente do contorno que está migrando é muito importante $(12,32)$. O grau de subdivisão interna, que muda de grão para grão, faz com que diferentes sistemas de escorregamento sejam ativados levando a formação de regiões com potenciais termodinâmicos distintos num mesmo grão (33).

Estes fatores afetam localmente a natureza da frente de recristalização, de forma que segmentos do contorno de um mesmo grão possuem mobilidades diferentes, migrando com diferentes velocidades. Isto leva à formação das protrusões, que são partes do contorno que avançam mais que as demais, enquanto que as retrusões são os segmentos que avançam menos (34-36) .

As primeiras observações de protrusões foram reportadas por Beck, Sperry e Hu $(36,37)$, ainda na década de 1950, na recristalização estática de alumínio de alta pureza, como mostra a Figura 3.5. Eles foram os primeiros a verificar 
experimentalmente que a mobilidade do contorno depende da desorientação do contorno e que diferentes segmentos do contorno migram com diferentes taxas.

Protrusões também foram reportadas em alumínio de alta pureza tanto na recristalização estática (38) como na dinâmica (39). Também foram observadas em ligas de alumínio $(40,41)$ e no cobre de alta pureza $(42,43)$ na recristalização dinâmica e na recristalização estática em ligas Al-Mn ( $0,1 \%$ e 0,3\% em peso de Mn) (44). Desta forma, estes resultados reportados na literatura permitem concluir que as protrusões podem surgir tanto na recristalização estática como na dinâmica.

Martorano e colaboradores (45), entretanto, foram os primeiros a reportar a formação de protrusões em materiais com estrutura CCC na recristalização estática de nióbio e tântalo de alta pureza. Além disso, propuseram uma explicação baseada na existência de diferenças periódicas (senoidais) da energia armazenada à frente do contorno de alto ângulo. Como consequência, variações periódicas na velocidade dos segmentos do contorno promovem a formação de estruturas de protrusões bastante peculiares. A Figura 3.6 mostra a presença de protrusões no contorno de grão de uma amostra de nióbio de alta pureza (45). Nela, fica evidente a existência de uma periodicidade e um anisotropia quanto à direção de crescimento destas estruturas (paralelas entre si). Nota-se, também, a inexistência de protrusões secundárias, perpendiculares à direção de crescimento, numa analogia com as dendritas secundárias na solidificação.

Figura 3.5 - Protrusões na recristalização estática em alumínio de alta pureza (MO).

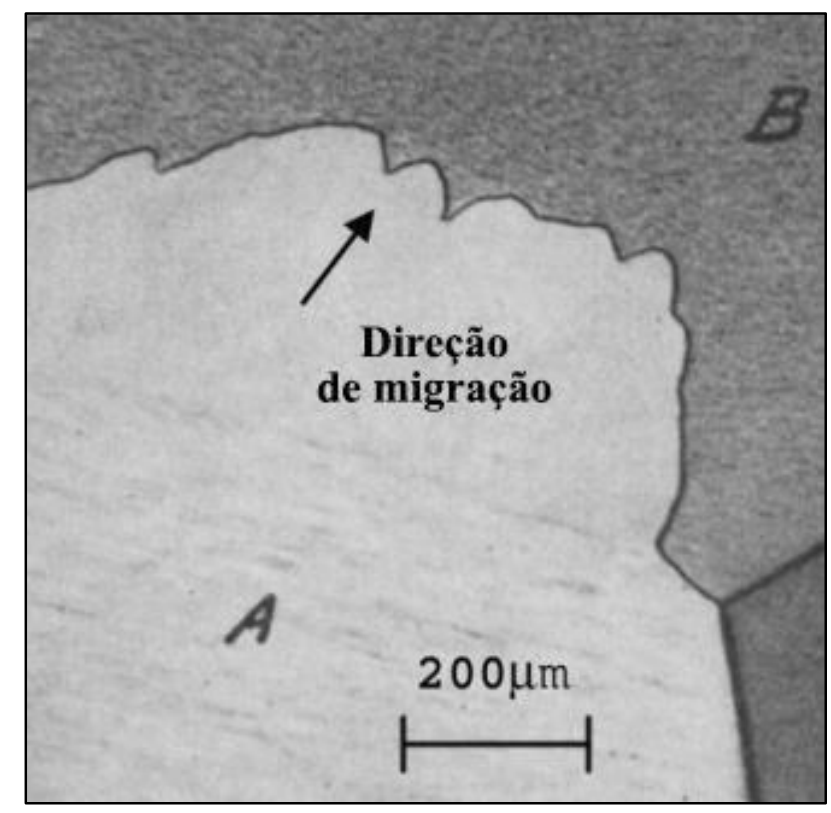

Fonte: Adaptada de (37). 
Em ligas metálicas, entretanto, a formação de protrusões pode ser explicada pelo ancoramento ou retardamento da velocidade de migração de parte do contorno por partículas de segunda fase e solutos, respectivamente; porém, este mecanismo não se aplica para materiais de alta pureza (45), como é o caso do material em estudo neste trabalho.

Schmidt e colaboradores foram os primeiros a observar in situ o crescimento (expansão) de um grão durante a recristalização em uma liga de alumínio comercialmente pura (AA1050) utilizando um arranjo experimental inovador, denominado "three-dimensional $x$-ray diffraction microscope", ou microscopia em 4D, sendo a quarta dimensão o tempo. Eles realizaram a reconstrução em 3D do novo grão à medida que a recristalização progredia. Esta reconstrução permitiu identificar de forma inequívoca que alguns segmentos dos contornos de grãos apresentavam formas irregulares e de modo transiente à medida que a interface migrava (46).

Para os autores, as protrusões são causadas por variação na pressãomotriz resultantes da distribuição não uniforme das discordâncias e dos contornos de baixo ângulo à frente do contorno de alto ângulo (46). A Figura 3.7 mostra uma sequência de imagens desta reconstrução passo a passo, evidenciando a presença de protrusões nas frentes de recristalização.

Figura 3.6 - Protrusões na recristalização estática em uma amostra de nióbio de alta pureza (MO).

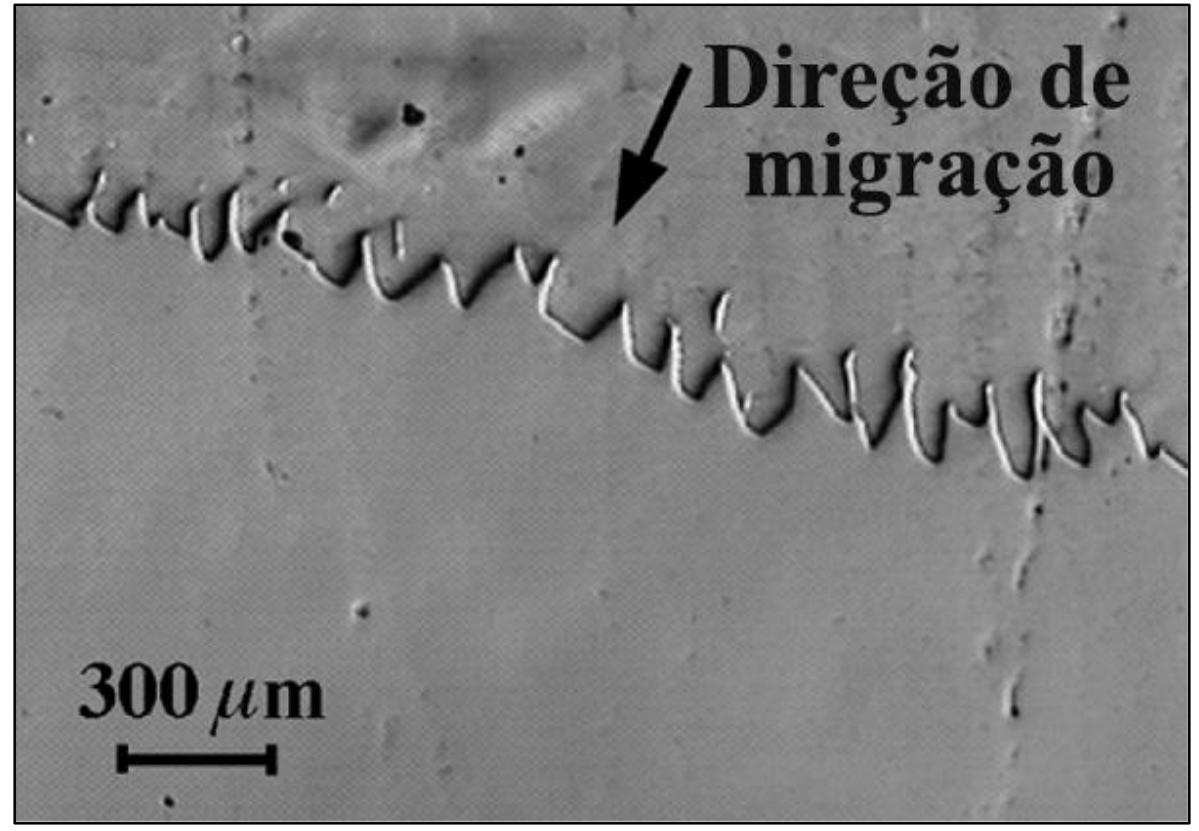

Fonte: Adaptado de (45). 
Figura 3.7 - Representação da reconstrução da expansão de um núcleo de recristalização usando a denominada microscopia em 4D. As letras de A até I indicam a sequência de captura das imagens com o tempo.
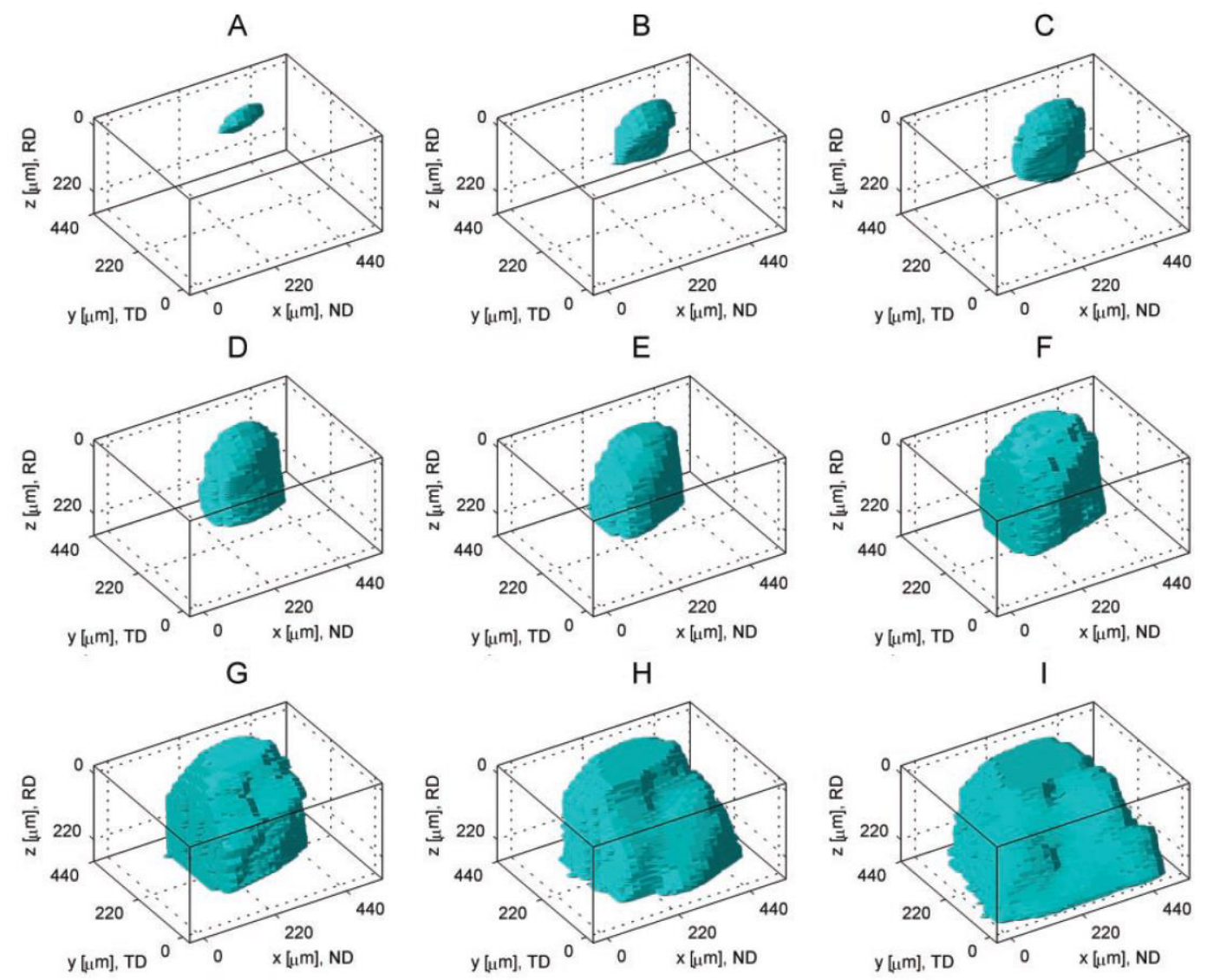

Fonte: (46).

Após esse primeiro e pioneiro estudo sobre o crescimento (expansão) de um único grão em 3D no alumínio outros três trabalhos posteriores foram realizados com o mesmo material (AA1050), porém, com diferentes orientações iniciais e diferentes graus de deformação (47-49). Todos esses estudos in situ da recristalização mostram que a migração dos contornos de grãos é muito mais complexa do que até agora assumido, que a taxa de migração não é constante e varia de grão para grão, no tempo e no espaço $(32,46-49)$.

A maioria dos autores afirma que as protrusões se formam devido às heterogeneidades locais da microestrutura que levam a uma variação na pressãomotriz e, portanto, na velocidade de migração do contorno (45,50-52). Existem diversos modelos teóricos para o crescimento das protrusões baseados nessa variação da pressão-motriz, tais como os apresentados por Martorano (53), Godiksen (54), Moelans (34,35), Zhang (55). Porém, o mecanismo para a formação 
das protrusões e como elas evoluem durante o recozimento ainda não estão claros (50).

Martorano, Fortes e Padilha (53) simularam a formação de protrusões utilizando a equação de cinética clássica de recristalização de forma modificada. A simulação é feita tanto para contornos inicialmente planos, como para contornos inicialmente circulares, como mostra a Figura 3.8. O modelo considera o empilhamento de discordâncias espaçadas de formas equidistantes e perpendiculares ao contorno de grão em migração, tal como ocorre num contorno de baixo ângulo do tipo inclinado. À medida que o contorno migra, ele absorve estas discordâncias, levando à formação das protrusões devido a maior velocidade local do contorno nestas regiões. O modelo utiliza muitas simplificações, porém ele explica de forma bastante simplificada as principais características da formação da protrusão durante a recristalização.

Figura 3.8 - Arranjo de discordâncias próximo ao contorno de grão em migração: (a) contorno plano; (b) contorno circular; (c) empilhamento de discordâncias em um contorno originalmente plano.
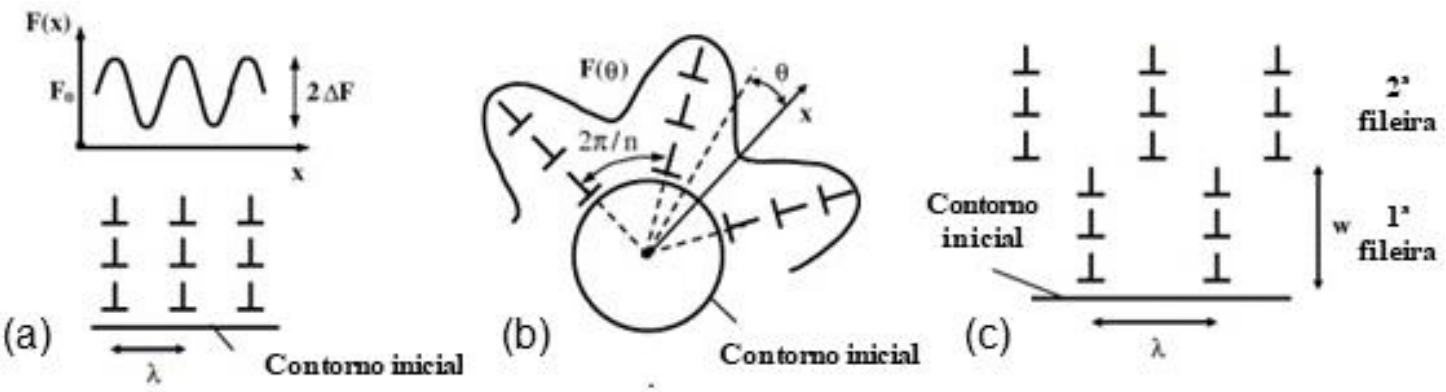

Fonte: (53).

Um trabalho de Zhang, Godfrey e Juul-Jensen (55) relacionaram a formação de protrusões com a energia armazenada durante a deformação. Neste trabalho são desenvolvidos dois métodos para calcular a quantidade de energia que existia na região onde a protrusão foi formada. Quando ocorre a formação da protrusão, a área do contorno de grão aumenta, e com isso aumenta a energia do contorno. Eles relacionam que a energia armazenada naquela região deve ser no mínimo igual (ou maior) a esse aumento de energia do contorno de grão. Os valores obtidos pelos dois métodos estão de acordo com a densidade média de energia armazenada no material deformado medida por meio de calorimetria diferencial de varredura (DSC, do inglês, differential scanning calorimetry).

Moelans e colaboradores (34) simularam a formação de protrusões e retrusões baseados em variações da energia armazenada durante a deformação. 
A microestrutura do material deformado é formada por células de discordâncias e a energia armazenada varia de acordo com uma função senoidal, onde o ponto de máxima energia é a posição do contorno da célula, e o ponto de mínima energia é o interior da célula. Uma das simplificações adotada neste trabalho é que a energia armazenada não varia com o tempo, isto é, ele não considera a extensão da recuperação do material. Vale ressaltar que o modelo não considera a desorientação que existe entre uma célula de discordância e outra. As simulações sugerem que a velocidade de migração é determinada principalmente pela forma que a energia está distribuída no material. O modelo também reproduz a assimetria que é observada experimentalmente entre os contornos de protrusão e retrusão.

Moelans e colaboradores (35) utilizaram os mesmos princípios, porém com menos simplificações. Neste trabalho a recuperação passa a ser considerada parcialmente, considerando a aniquilação de discordâncias de sinais opostos que estejam no mesmo plano. Considera que o material deformado é formado por empilhamentos de discordâncias igualmente espaçados e para a simulação são utilizados dois espaçamentos diferentes, mas a energia total armazenada é a mesma. Além dos dois espaçamentos, a simulação é realizada tanto no eixo $\mathrm{x}$ quanto no eixo y. A Figura 3.9 mostra os resultados desta simulação.

A simulação com espaçamento de 1,66 $\mu \mathrm{m}$ tem duas situações possíveis. Na primeira (Figura 3.9 (b)), o movimento dos contornos de grão é de baixo para cima. As partes do contorno de grão, indicadas em vermelho, mostram um movimento do tipo stop-and-go, onde stop-and-go é o movimento do contorno onde este move-se, para, e move-se novamente. Isto ocorre porque partes do contorno que estão próximas das regiões de mínima energia permanecem por um período mais longo na mesma posição até avançarem para o próximo ponto de mínima energia. Na segunda (Figura 3.9 (c)), o movimento dos contornos de grão é da esquerda para a direita. Protrusões e retrusões quase simétricas se desenvolvem ao longo da frente de recristalização durante a migração. As protrusões se transformam em retrusões e vice-versa, de maneira contínua, enquanto o contorno de grão migra, devido às variações locais das distribuições da energia de deformação armazenada.

A simulação realizada com espaçamento de 6,18 $\mu \mathrm{m}$ também apresenta duas situações possíveis e mostra resultados diferentes dos obtidos para o menor espaçamento. Na primeira (Figura 3.10 (b)), o movimento do contorno é de baixo 
para cima. Partes do contorno de grão (indicadas com o destaque vermelho) apresentam um movimento chamado de stop-and-go with pinch-off, onde stop-andgo é igual descrito anteriormente. A diferença neste caso é o pinch-off (pinçamento) que é quando parte do contorno de grão fica um tempo muito longo na mesma posição, enquanto o restante do contorno continua avançando. Em determinado momento, o contorno de grão da parte estagnada se toca formando uma ilha de material deformado que fica para trás, enquanto o contorno segue. Na segunda (Figura 3.10 (c)), o movimento do contorno de grão é da esquerda para a direita. Protrusões e retrusões assimétricas são formadas ao longo da frente de recristalização, onde as retrusões apresentam curvaturas consideravelmente maiores que as protrusões. Protrusões se transformam em retrusões e vice-versa, de maneira contínua, enquanto o contorno de grão migra.

Esta simulação mostra que a movimentação dos contornos é mais irregular para maiores distâncias entre os espaçamentos das discordâncias, mostrando a grande influência do tamanho de grão, sua orientação e da distribuição de defeitos na matriz deformada. Ou seja, quanto mais heterogênea é esta distribuição, mais irregular é o contorno de grão recristalizado.

Zhang e colaboradores (56) estudaram a formação de protrusões em alumínio de alta pureza por meio da técnica de canalização de elétrons num microscópio de varredura (electron channeling contrast imaging, $\mathrm{ECCl}$ ) e medidas de EBSD in situ durante o recozimento. A Figura 3.11 mostra a movimentação do contorno de grão durante a recristalização. Segundo os autores a distribuição dos arranjos de discordâncias no material deformado define a migração do contorno de grão localmente, sendo assim a migração do contorno é definida muito bem de forma qualitativa. Entretanto, descrever o fenômeno de forma quantitativa é mais complicado, pois um grande desvio entre a velocidade do contorno e a pressão motriz local é observado. Provavelmente este desvio está relacionado com a incerteza do valor da mobilidade do contorno, a qual é complexa e depende de muitos parâmetros, e também com o fato que a movimentação de determinados segmentos do contorno afeta o movimento dos segmentos vizinhos. 
Figura 3.9 - Simulação da migração dos contornos de alto ângulo durante a recristalização: (a) Representação da variação de energia utilizando uma escala de cor, onde o preto representa a densidade de energia mais alta e branco uma densidade de energia igual a zero, para o espaçamento de 1,66 $\mu \mathrm{m}$; (b) posições dos contornos de grão em função do tempo, movimentação do contorno de baixo pra cima; (c) posições dos contornos de grão em função do tempo, movimentação do contorno da esquerda para a direita.

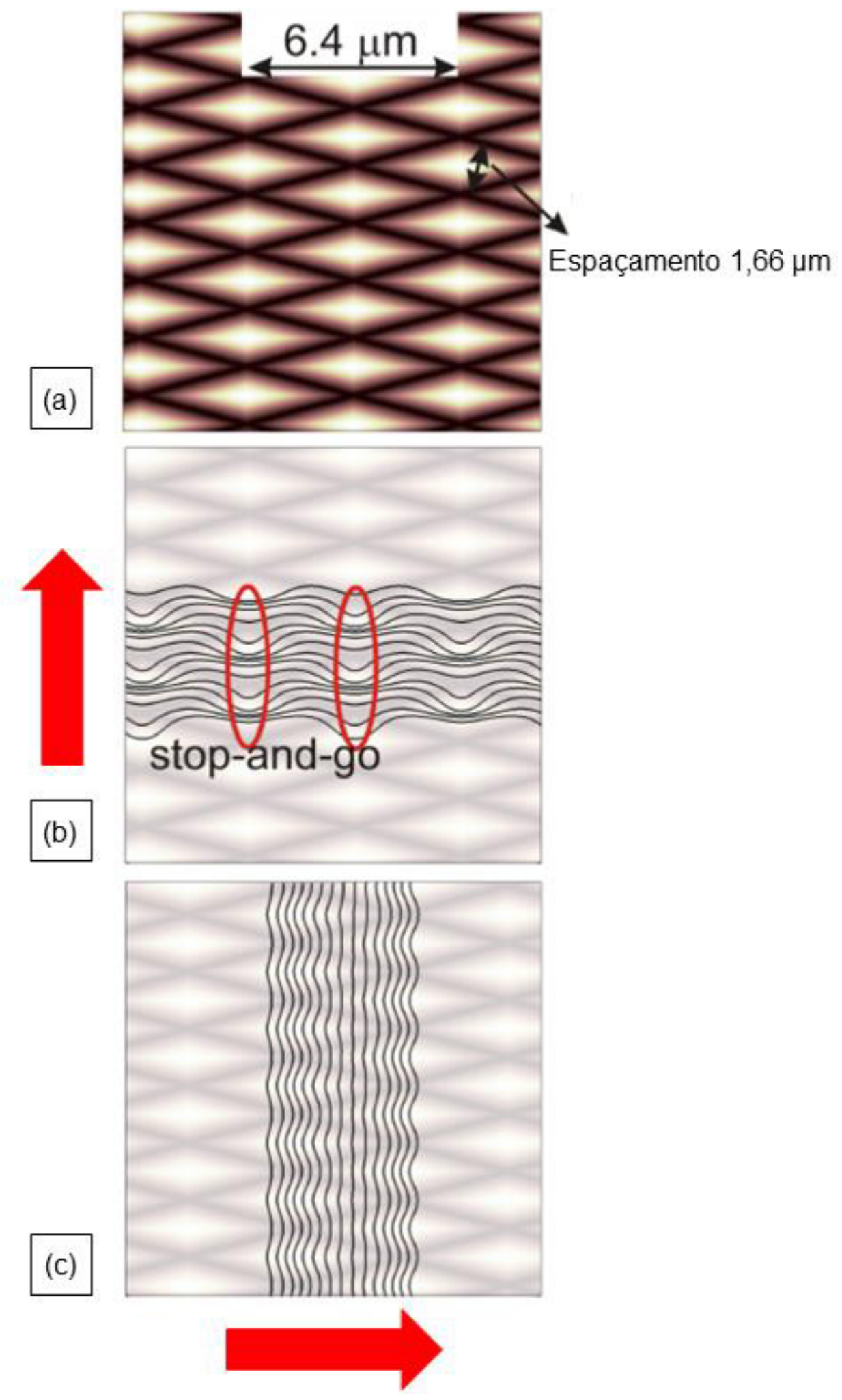

Fonte: (35) 
Figura 3.10 - Simulação da migração dos contornos de alto ângulo durante a recristalização: (a) Representação da variação de energia utilizando uma escala de cor, onde o preto representa a densidade de energia mais alta e branco uma densidade de energia igual a zero, para o espaçamento de 6,18 $\mu \mathrm{m}$; (b) posições dos contornos de grão em função do tempo, movimentação do contorno de baixo pra cima; (c) posições dos contornos de grão em função do tempo, movimentação do contorno da esquerda para a direita.

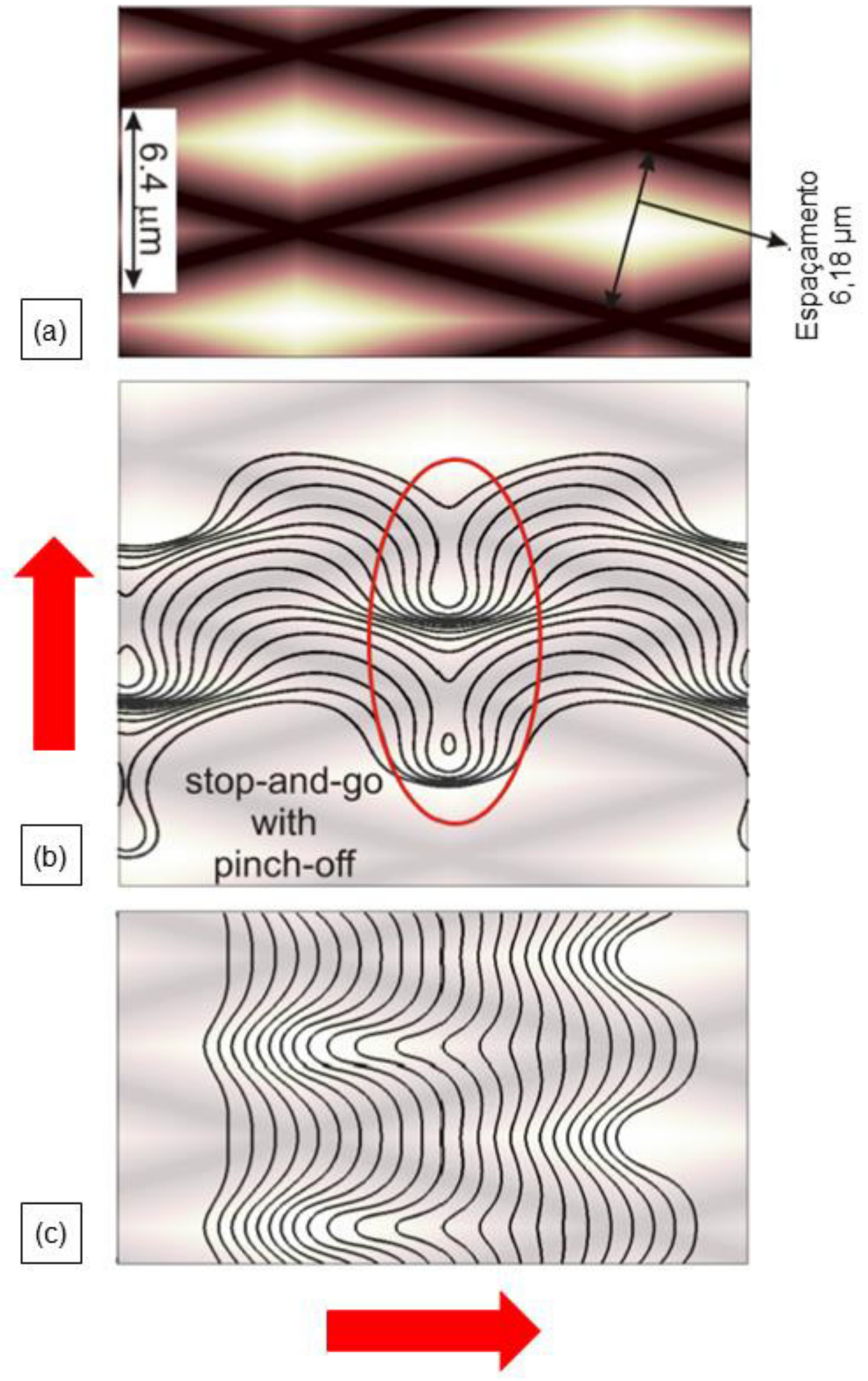

Fonte: (35). 
Figura 3.11 - Movimentação do contorno durante a recristalização: (a) Imagem de ECCl, onde a seta preta indica uma protrusão e a branca uma retrusão; (b) mapeamento de EBSD; (c) indicação das posições do contorno de grão recristalizado durante o recozimento, intervalo de $500 \mathrm{~s}$ entre cada indicação.
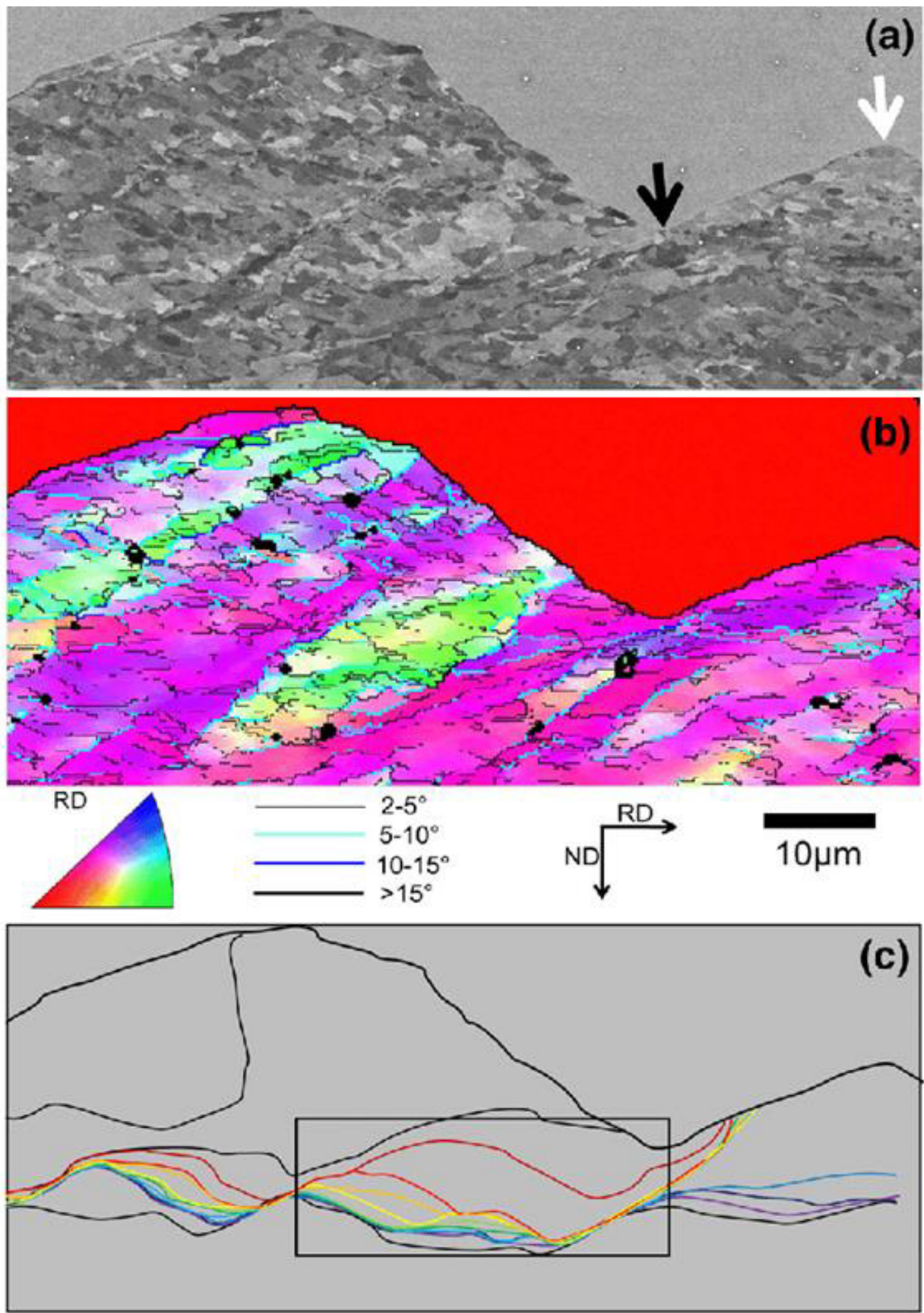

Fonte: (56). 
A movimentação dos contornos é complexa, uma vez que eles se movem, param e movem-se outra vez. Além disso, observa-se que a velocidade de expansão varia de forma significativa de grão para grão (57). O contorno de grão possui uma estrutura dinâmica, então as protrusões podem desaparecer e transformarem em retrusões, e vice-versa $(34,35)$. Eventuais efeitos de microssegregação junto aos contornos e a dissolução de precipitados, assim como efeitos advindos da recuperação, podem alterar de forma significativa as condições locais dos potenciais termodinâmicos e as forças de arraste. A observação experimental e a quantificação destes efeitos na formação de protrusões são uma tarefa bastante árdua, face à escala na qual estes efeitos se manifestam.

A Figura 3.12 mostra um contorno grão migrando com a formação de protrusões e retrusões em direção a uma área formada por subgrãos. Para alguns autores a formação de protrusões pode estar relacionada com o encontro dos contornos de grão com células de discordâncias e/ou subgrãos (45).

A desorientação do contorno é um parâmetro muito importante para a mobilidade e, consequentemente, a velocidade de crescimento dos núcleos, afetando a recristalização. Porém, é importante ressaltar que não somente núcleos com (des)orientações favoráveis podem levar a uma alta mobilidade, como mostra o trabalho de Fan e colaboradores (58). É necessário que a esses núcleos estejam associados gradientes de desorientação locais com elevada energia armazenada, pois estas regiões contribuem para a um rápido crescimento. No trabalho reportado por Fan e colaboradores, um tricristal de alumínio foi laminado a frio e recozido. Em seguida, a superfície perpendicular superior, em relação à superfície analisada, foi lixada e polida, enquanto que a superfície perpendicular inferior foi apenas lixada, para induzir a formação de um maior número de núcleos de recristalização nesses locais. A microestrutura parcialmente recristalizada é mostrada na Figura 3.13. Analisando inicialmente apenas as regiões não recristalizadas, é evidente a diferença no grau de subdivisão dos grãos. $O$ grão $B$ encontra-se menos subdividido, enquanto que o grão $A$ apresenta uma maior subdivisão, exibindo bandas de deformação e de transição. A escala de cores mostra que o grão $\mathrm{A}$ apresenta elevada desorientação desde o contorno com $B$ até o final da região observada. Dois sítios preferenciais de nucleação são observados: bandas de deformação e superfície. $O$ trabalho também destaca que a maioria dos núcleos 
formados tem o contorno do tipo $\Sigma 7$, o qual, sabidamente apresenta elevada mobilidade em metais com estrutura CFC (58).

Para mais bem compreender a formação de protrusões e retrusões e sua importância para a recristalização, são necessários métodos de quantificação da desorientação entre 0 núcleo de recristalização e as regiões deformadas adjacentes. Zhang e colaboradores (57) estudaram a área que é consumida durante a migração do contorno na recristalização de níquel de alta pureza para a quantificação da velocidade de migração do contorno. Eles comprovaram que a diferença de orientação é um parâmetro importante, entretanto, comparando-se a diferença de orientação em relação à vizinhança encontrada nos contornos que se moveram e os que não se moveram durante o recozimento, relataram que a diferença observada não era grande. Uma outra razão que poderia levar a alguns segmentos migrarem e outros não, poderia ser a energia armazenada na matriz deformada logo à frente do contorno. Porém, como mostra a Figura 3.14, foram escolhidos dois grãos, $A$ e $B$, que apresentavam a mesma orientação e desorientação em relação à matriz deformada. A pressão-motriz a frente do contorno foi calculada (para cada retângulo) e é semelhante para os dois grãos. Porém, alguns contornos migraram e outros não para maiores tempos de recozimento (57). Os resultados sugerem que a migração dos contornos é complexa, não depende apenas da diferença de orientação e, possivelmente, outros fatores ainda não identificados podem influenciar este comportamento $(56,57)$.

Sun e colaboradores desenvolveram um método para quantificar a rugosidade do contorno por meio de análise de imagens e, portanto, associá-la à presença de um número maior ou menor de protrusões (59). Recentemente, esse método foi utilizado por Sun, Zhang e Juul Jensen para medir a rugosidade do contorno em amostras de alumínio levando em consideração apenas o contorno formado entre regiões recristalizadas e deformadas (recuperadas), comparando materiais com e sem partículas, com diferenças de orientação e quantidades de deformação variáveis. 
Figura 3.12 - Tântalo deformado até $\varepsilon=1,3$ e recozido em $900^{\circ} \mathrm{C}$ por 30 min (MEV - elétrons retroespalhados), mostrando um contorno de alto angulo migrando em direção a uma área formada por subgrãos.

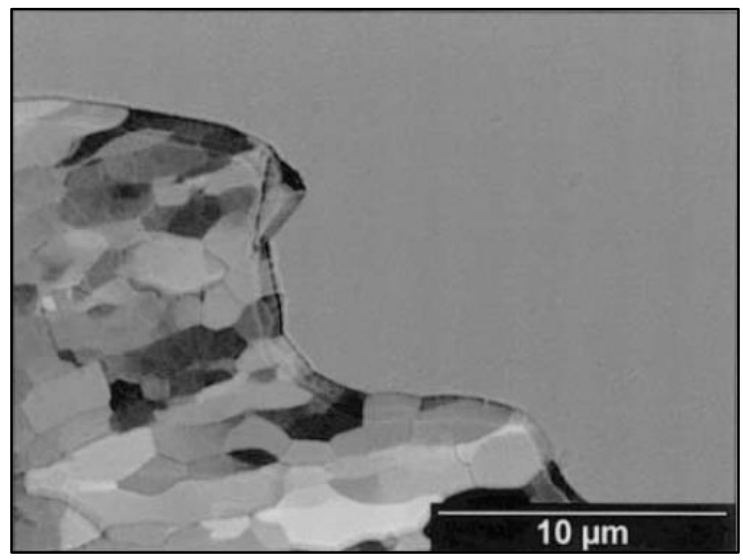

Fonte: (60).

Figura 3.13 - Mapa de EBSD mostrando a microestrutura parcialmente recristalizada.

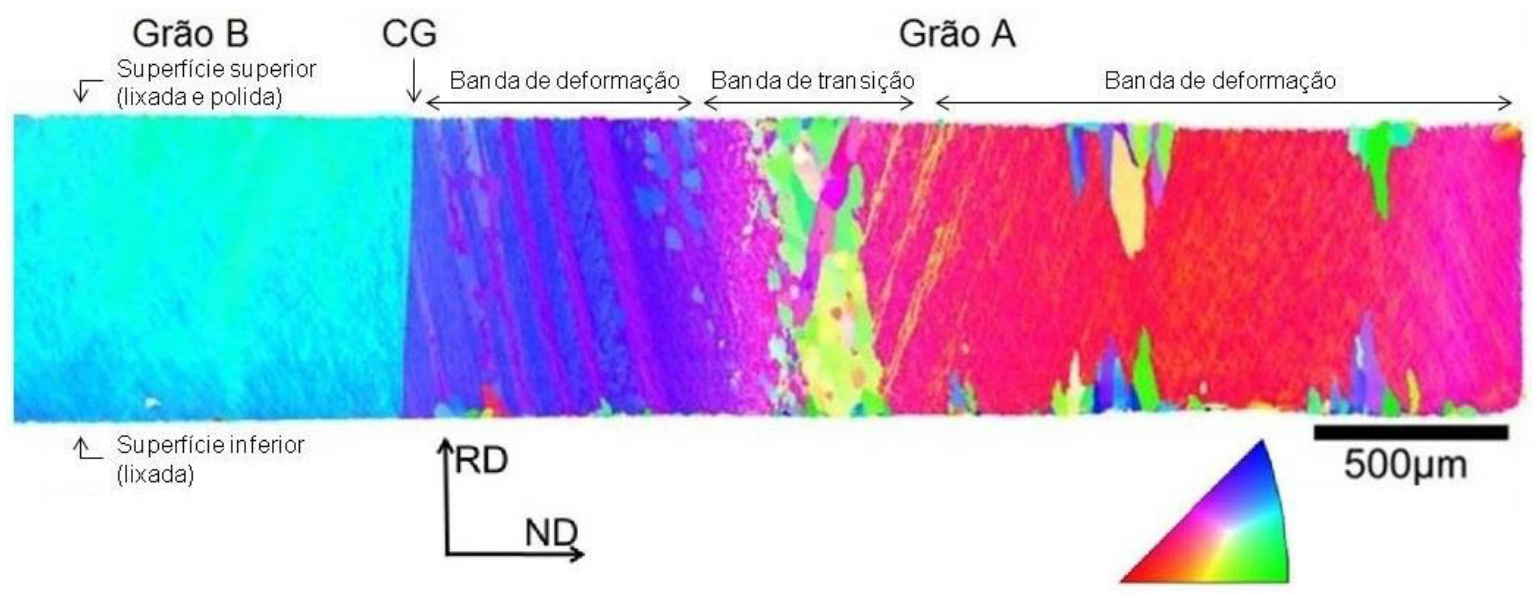

Fonte: Adaptado de (58).

Figura 3.14 - Diferença na velocidade de migração entre dois grãos praticamente da mesma orientação e diferenças de orientação semelhantes em relação à matriz recuperada. Tempo de recozimento: (a) 7,5 min; (b) 7,5 + 7,5 min.

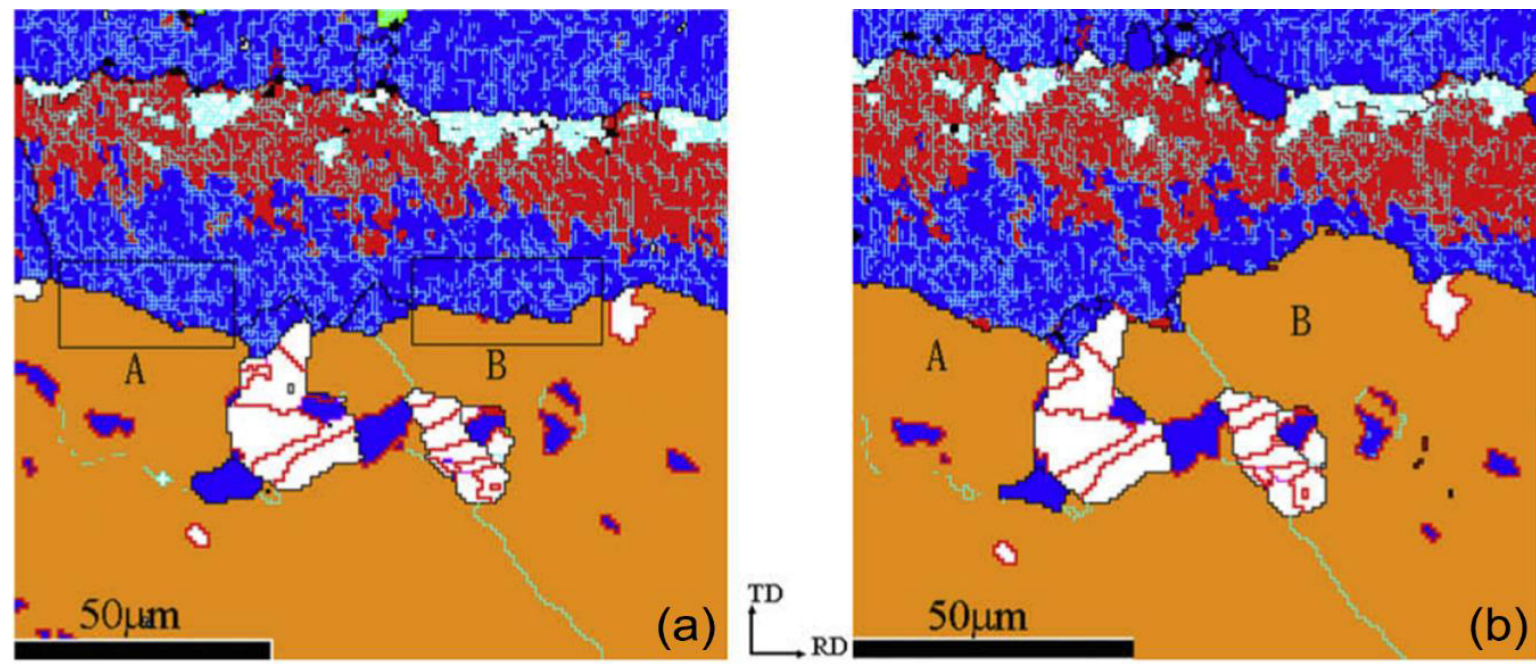

Fonte: (57). 
A rugosidade do contorno é explicada pela heterogeneidade de deformação da microestrutura. Segmentos de contornos recristalizados com diferentes arranjos de discordâncias à frente apresentam diferenças na escala da rugosidade, indicando que a interação entre o contorno móvel e os contornos de baixo ângulo oriundos da estrutura recuperada afeta fortemente a migração dos contornos de alto ângulo durante a recristalização (61).

Um trabalho recente de Zhang e Juul Jensen (62) traz uma síntese sobre as novas descobertas na área de migração de contornos com foco nas técnicas de caracterização. Para uma maior compreensão do tema e resolução desses problemas, é necessário um maior número de investigações na área. As principais questões em aberto apontadas pelos autores são:

a) Qual a relação entre a formação de protrusões e de retrusões com a heterogeneidade da matriz deformada quanto à distribuição dos defeitos à frente do contorno em migração?

b) Existe alguma relação entre a natureza do contorno (inclinado ou torcido) e o potencial para formar protrusões e retrusões?

c) Qual é a magnitude mínima necessária desta não-uniformidade na distribuição da energia armazenada para permitir a formação de protrusões?

d) A formação de protrusões afeta a taxa de migração global dos contornos?

Na presente Tese, essas questões são abordadas por meio de inspeção metalográfica convencional, medidas de EBSD convencionais e em três dimensões com o uso de polimento sequencial. Em especial, há particular interesse e originalidade na investigação do eventual efeito da natureza do plano do contorno na formação de protrusões. Para tal, experimentos exploratórios utilizando EBSD em 3D serão realizados para esse propósito. 


\subsection{EDSD em 3D}

A maior parte das caracterizações metalográficas são realizadas em 2D, porque, em geral, as características estereológicas permitem inferir sobre parâmetros tridimensionais por meio de equações bastante simples. Porém, em determinados casos é necessário um estudo em 3D da microestrutura, pois nem todos os parâmetros da microestrutura podem ser determinados a partir de uma simples análise em 2D. No caso de um contorno de grão, pelo menos cinco variáveis o definem. Os três parâmetros que especificam a desorientação da rede (ou o tipo de contorno CSL) não são suficientes para determinar a grau de coincidência no plano do contorno do grão. Para caracterizar a coincidência no plano do contorno de grão, é também necessário especificar a orientação do plano de contorno de grão. Em outras palavras, cinco parâmetros independentes são necessários para determinar a densidade de sítios coincidentes no plano do contorno (63).

Os mapas de orientação convencionais em 2D fornecem quatro dos cinco parâmetros necessários para classificar cada contorno de grão: os três parâmetros de desorientação de rede e um dos dois parâmetros necessários para descrever a orientação do plano do contorno. Para extrair a distribuição completa de cinco parâmetros, utiliza-se seccionamento seriado ou uma análise estereológica dos dados de uma seção planar (63).

Esse tema ganha relevância, pois inúmeras propriedades dos materiais policristalinos derivam da natureza dos contornos de grão que os compõem, tais como a resistência à corrosão, à fluência e algumas propriedades mecânicas. Dentre essas propriedades, sem dúvida alguma a mobilidade dos contornos exibe essa dependência. Diversos trabalhos de revisão abordam o tema (23,64-66). A característica do plano do contorno afeta a mobilidade e influencia sua cinética de migração. A absorção de defeitos (discordâncias) durante a migração e a mudança do caráter dos planos dos contornos com a temperatura são alguns complicadores para o estabelecimento de modelos abrangentes para descrever o fenômeno. A variação da mobilidade dos contornos é de absoluta relevância no estudo da recristalização e do crescimento de grão, em particular $(23,64,65)$.

O seccionamento seriado é uma forma mais simples de caracterização 3D. Para tal, são realizados cortes ou etapas de polimento consecutivas na amostra. A 
cada etapa de seccionamento, a seção é caracterizada ou mapeada e os dados são armazenados. Ao final a microestrutura 3D é reconstruída com o empilhamento dos mapas em 2D por meio de um software adequado. Para o seccionamento da microestrutura os principais métodos utilizados são o polimento sequencial, polimento químico, corte a laser ou abrasão por descarga elétrica (67). Para caracterizar a microestrutura em cada seção todas as técnicas de microscopia podem ser utilizadas. Os principais desafios associados a muitos dos métodos de seccionamento estão no controle da profundidade de seccionamento, na obtenção de superfícies planas e paralelas e na detecção e alinhamento correto da área de observação. O uso de EBSD em 3D por meio de seccionamento seriado após consecutivas etapas de polimento mecânico convencional foi a técnica escolhida por propiciar poucos danos à superfície em estudo e produzir seções bastante finas, com espessura da ordem de $1 \mu \mathrm{m}$, aumentando a precisão do método.

Uma técnica que evita esses problemas é a combinação de seccionamento serial utilizando um feixe de íons (FIB, do inglês, focused ion beam) com o EBSD. A desvantagem desta técnica é a pequena área analisada, o longo tempo necessário para o desbaste e o custo do equipamento (dual beam), além da introdução de defeitos e íons de gálio na superfície da amostra.

\subsection{Textura em metais com estrutura CCC}

Os materiais cristalinos podem se estruturar como monocristais, oligocristais e policristais. Cada grão apresenta uma orientação cristalográfica diferente da apresentada por seus vizinhos imediatos e a orientação de todos os grãos do material pode estar distribuída de forma aleatória em relação a um referencial ou concentradas ao redor de uma ou mais orientações preferenciais. Neste caso, um número significativo de grãos que compõem o material policristalino possui uma dada orientação preferencial, ou seja, exibe textura cristalográfica (5,68-70). A importância da textura deve-se ao fato de ela estar associada diretamente a várias propriedades dos materiais, como por exemplo, a ductilidade, a tenacidade, a permeabilidade magnética e a condutividade elétrica, pois essas propriedades podem ser fortemente anisotrópicas, isto é, dependem da orientação do material $(68,70,71)$. 
A textura desenvolvida em uma amostra depende do material, do processamento mecânico e dos tratamentos térmicos a que ela foi submetida. Deste modo, deformação plástica, recuperação, recristalização e crescimento de grão podem alterar de modo significativo a textura $(5,70,72)$.

Para os materiais laminados, a textura de chapa é representada pelos índices de Miller de um dado plano ( $h k l$ ) paralelo à superfície do metal laminado e a direção $[u v w]$ paralela à direção de laminação $(4,68,73)$. As componentes de textura mais observadas nos materiais CCC deformados são as fibras $\alpha$ e $\gamma$, as quais normalmente são representadas no espaço de Euler na sessão de $\varphi_{2}$ constante de $45^{\circ}$ da função de distribuição de orientações (ODF, do inglês, orientation distribution function). A Figura 3.15 (a) mostra essa seção representando as duas principais fibras, enquanto que a Figura 3.15 (b) mostra o resultado experimental para um aço IF (interstitial-free). As principais fibras encontradas nos metais $\mathrm{CCC}$ e as respectivas direções e componentes são mostradas na Tabela $3.1(4,74)$.

Porém, a representação de texturas por meio de ODFs só é válida para descrever regiões mapeadas com um grande número de grãos, pois a textura trata de uma representação estatística das orientações presentes em um policristal. Para representar a orientação de monocristais ou materiais com poucos grãos é preferível utilizar as figuras de polo discretas ou figuras de polo inversas.

A textura de recristalização de metais CCC é bastante similar à textura de deformação em termos de componentes presentes e também pode ser descrita utilizando-se as fibras $\alpha$ e $\gamma$. Alguns trabalhos com nióbio e tântalo mostram que as principais texturas encontradas são as que contêm as fibras $\alpha$ e $\gamma(73,75)$.

$\mathrm{Na}$ presente Tese, os resultados serão expressos preferencialmente na forma de figuras de polo, tanto para expressar suas orientações iniciais como as diferenças de orientação com a matriz deformada, uma vez que o número de grãos envolvido é baixo. 
Figura 3.15 - Sessão de $\varphi 2=45^{\circ}$ de uma ODF mostrando as principais texturas para os materiais CCC: (a) localização das componentes de texturas mais importantes; (b) resultado experimental de um aço IF laminado a frio.

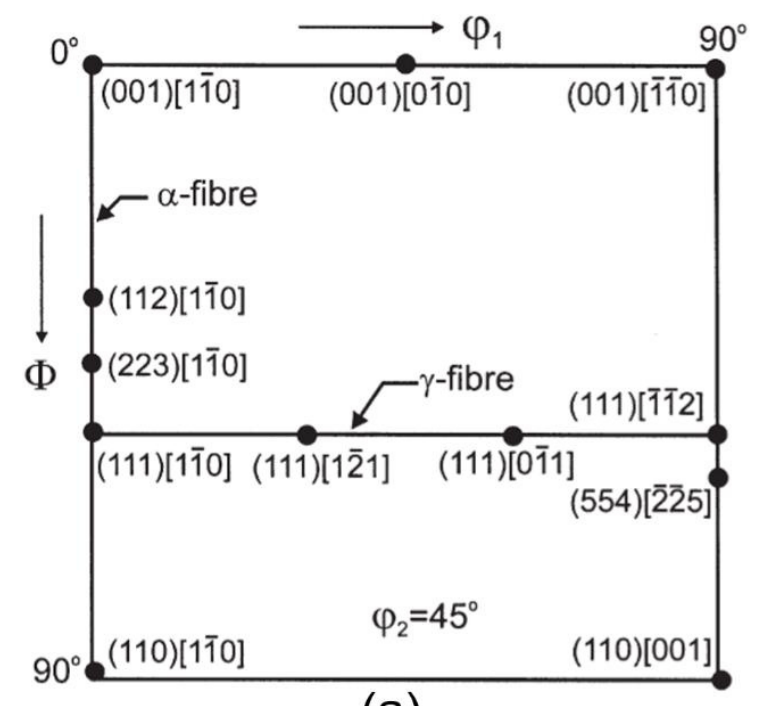

(a)

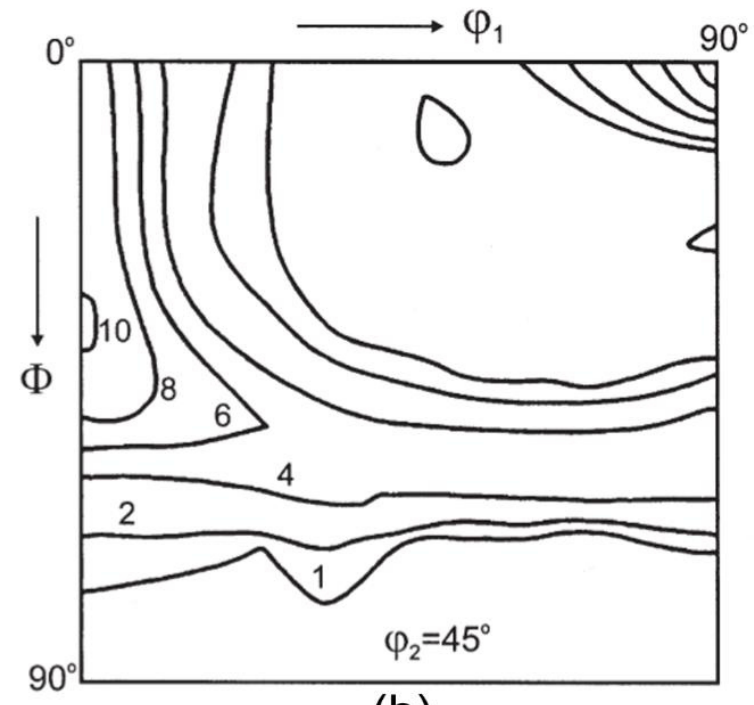

(b)

Fonte: (4).

Tabela 3.1 - Características das principais fibras de metais CCC

\begin{tabular}{|c|c|c|}
\hline Fibra & Eixo da fibra & Orientações da fibra \\
\hline$\alpha$ & $<110>/ / \mathrm{DL}$ & $\begin{array}{l}\{001\}<110> \\
\{112\}<110> \\
\{111\}<110>\end{array}$ \\
\hline$\gamma$ & $<111>/ / \mathrm{DL}$ & $\begin{array}{l}\{111\}<110> \\
\{111\}<112>\end{array}$ \\
\hline$\eta$ & $<001>/ / D L$ & $\begin{array}{l}\{001\}<100> \\
\{011\}<100> \\
\{001\}<110> \\
\{112\}<111>\end{array}$ \\
\hline$E$ & $<110>/ / D T$ & $\begin{array}{c}\{011\}<011> \\
\{011\}<111> \\
\{4411\}<11118> \\
\{111\}<112> \\
\{011\}<100>\end{array}$ \\
\hline
\end{tabular}

Fonte: (74). 


\section{MATERIAIS E MÉTODOS}

\subsection{Material}

O material de partida para a realização desta Tese foi uma chapa de nióbio oligocristalino obtido a partir de um lingote de alta pureza com $200 \mathrm{~mm}$ de diâmetro e $600 \mathrm{~mm}$ de altura, produzido com múltiplas fusões num forno de feixe eletrônico Leybold-Heraeus modelo ES 2/18/30, instalado no DEMAR-EEL-USP. De agora em diante, todos os equipamentos listados neste capítulo encontram-se instalados no DEMAR-EEL-USP, salvo haja menção expressa em contrário. A partir do lingote de nióbio foi retirada uma chapa com 9,2 $\mathrm{mm}$ de espessura. Os teores de impurezas intersticiais $(\mathrm{O}<50, \mathrm{~N}<5$, ppm em peso) e substitucionais $(\mathrm{W}<55, \mathrm{Fe}<45, \mathrm{Al}<$ 30 e $\mathrm{Si}<50$, ppm em peso) estão de acordo com os especificados da ASTM B 391-18 (76). Para este trabalho foram escolhidos cinco grãos do material inicial de forma aleatória, sendo estes nomeados consecutivamente de A a E.

\subsection{Métodos experimentais}

\subsubsection{Laminação}

O material foi laminado a frio, sem lubrificação, em múltiplos passes num laminador two-high/four-high da marca Fenn modelo 4-105. A laminação ocorreu até $50 \%$ de redução na espessura na direção do comprimento da chapa, sendo a espessura final nesta etapa de $4,6 \mathrm{~mm}$. Na sequência a chapa foi seccionada em duas partes, sendo uma delas laminada até $70 \%$ de forma direta (mantendo-se a direção inicial de laminação) e a outra laminada até $70 \%$ de forma cruzada, isto é, sofrendo uma rotação de $90^{\circ}$ no eixo $\mathrm{DN}$, onde $\mathrm{DN}$ é a direção normal a chapa. A espessura final das amostras laminadas até $70 \%$ de redução de espessura é de 2,8 mm. A Figura 4.1 mostra esquematicamente a chapa, como ocorreu a laminação e os eixos adotados, sendo DL a direção de laminação e DT a direção transversal. 
Figura 4.1 - Representação da chapa e dos eixos para a laminação direta e cruzada.

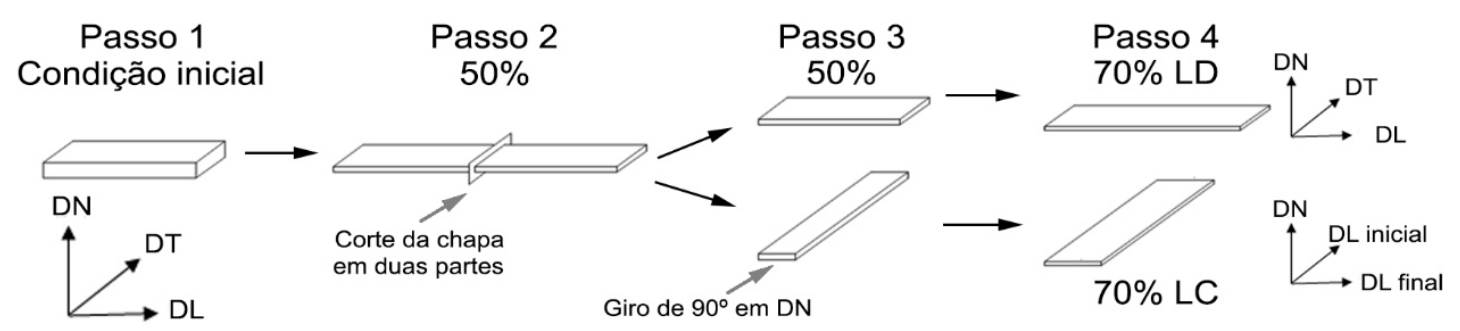

Fonte: a autora.

\subsubsection{Recozimentos isotérmicos}

Após a laminação a frio as amostras foram cortadas com disco diamantado numa máquina de corte da Buehler modelo ISOMET 1000. Como os grãos possuem largura na faixa de uns poucos centímetros, foi possível cortar amostras pertencentes ao interior de cada um dos grãos com o objetivo de acompanhar as mudanças microestruturais e avaliar a existência de eventuais efeitos de orientação. Para evitar possíveis erros de notação e/ou amostragem, as amostras foram cortadas longe dos antigos contornos de grão. Em seguida, as amostras foram limpas em ultrassom e encapsuladas em vácuo em tubos de quartzo.

Os recozimentos isotérmicos foram realizados em 800, 900, 1000, 1100 e $1200^{\circ} \mathrm{C}$ durante 60 min num forno tubular Lindberg-Blue. As amostras foram inseridas no forno previamente aquecido, aguardando a estabilização da temperatura, para então iniciar a contagem do tempo. O resfriamento ocorreu em água. A temperatura e tempo de tratamento foram escolhidos com base em um trabalho de Iniciação Científica anterior apoiado pela FAPESP, também em nióbio oligocristalino (77).

\subsection{Caracterização microestrutural}

\subsubsection{Preparação metalográfica}

Neste trabalho, adotou-se o estudo preferencial da seção DL x DT, ou seja, o plano de laminação, como mostra a Figura 4.1. As análises foram realizadas na metade da espessura da amostra para evitar artefatos oriundos da deformação cisalhante que predomina junto à superfície. Para tal, as amostras foram embutidas 
em resina fenólica condutora PoliFast da Buehler e passaram por desbaste em lixas de SiC seguido de polimento mecânico utilizando uma suspensão de sílica coloidal OP-S (Struers). As amostras selecionadas para medidas de EBSD passaram por uma etapa adicional de polimento vibratório com uma suspensão de sílica coloidal MasterMet ${ }^{\mathrm{TM}} 2$ (Buehler).

\subsubsection{Microscopia ótica e microscopia eletrônica de varredura}

Após a preparação metalográfica, as amostras foram caracterizadas via microscopia ótica (MO) utilizando-se um microscópio Leica, modelo DM IRM com uma câmera analógica Leica modelo DFC 295. Para aquisição e o processamento das imagens foi utilizado o software Leica Application Suite 3.8. As amostras também foram caracterizadas via microscopia eletrônica de varredura de alta resolução (MEV) em um MEV-FEG (field emission gun) Merlin da Zeiss, instalado no Max-Planck-Institut für Eisenforschung (MPIE), Düsseldorf, Alemanha. As imagens foram geradas no modo elétrons retroespalhados. Em todas as micrografias, a direção de laminação final foi posicionada paralela à barra de escalas, e as imagens foram obtidas sem ataque metalográfico.

\subsubsection{Difração de elétrons retroespalhados}

Amostras nas condições inicial, laminada e recozida isotermicamente foram preparadas metalograficamente e analisadas por difração de elétrons retroespalhados para a determinação da orientação inicial dos grãos $A, B, C, D$ e E e as micro e mesotexturas. As análises foram realizadas em dois equipamentos diferentes por meio de aquisição e identificação automatizada dos padrões de Kikuchi, sendo um o microscópio eletrônico de varredura JEOL modelo JSM-6500F equipado com canhão de emissão de campo instalado no MPIE em Düsseldorf (Alemanha) e o outro um microscópio eletrônico de varredura FEG-SEM Quanta 200 acoplado a um sistema da Pegasus (TSL-OIM), instalado no Instituto de Física de Rosário (IFIR) em Rosário (Argentina). Dependendo da extensão da área mapeada, diferentes valores de step size ${ }^{1}$ foram escolhidos, variando de $30 \mathrm{~nm}$ a

${ }^{1}$ Ao longo do texto, será mantida a notação step size. A tradução direta para o português não reflete o significado físico deste parâmetro experimental. 
$4 \mu \mathrm{m}$. Os resultados dos mapeamentos de EBSD foram indexados e analisados com o auxílio dos softwares OIM da TSL versão 7.3b e Matlab@ (utilizando a toolbox MTEX 4.5.3beta, desenvolvida para análise de orientações cristalográficas). Os parâmetros de processamento para ambos softwares foram: os pixels com índice de confiança menor que 0,1 foram removidos dos mapeamentos e os contornos de grãos são considerados de alto ângulo quando apresentam uma desorientação $\geq 15^{\circ}$ e de baixo ângulo quando apresentam valores entre $2^{\circ}$ e $15^{\circ}$. Valores de desorientação menores são descartados devido ao limite inerente na precisão das medidas de EBSD.

No caso da técnica de EBSD em três dimensões, doravante denominada EBSD em $3 D$, as amostras foram polidas sequencialmente em intervalos de $\approx 1,5$ $\mu \mathrm{m}$ por meio de polimento metalográfico convencional utilizando uma suspensão de sílica coloidal. Os equipamentos utilizados foram os mesmos utilizados nas medidas convencionais. O software QUBE 1.2 foi utilizado para empilhar e organizar as 18 seções obtidas, além de permitir acesso direto às informações sobre a cristalografia. A caracterização do caráter dos contornos foi feita sob a supervisão do Prof. Dr. Stefan Zaefferer do MPIE.

\subsubsection{Dureza Vickers}

Os ensaios de dureza Vickers foram realizados nas amostras na condição inicial (lingote), nas laminadas até $50 \%$ e nas laminadas até $70 \%$ de forma cruzada. O ensaio não foi realizado nas amostras laminadas até $70 \%$ de forma direta devido ao empenamento da chapa. Estes ensaios foram realizados num durômetro Reicherter tipo BVR, segundo a norma ASTM E 92-16 (78), com carga de $10 \mathrm{~kg}$ e tempo de aplicação de $20 \mathrm{~s}$. Em todas as seções analisadas foram realizadas 15 medidas diferentes distribuídas de forma uniforme por toda superfície. O ensaio de microdureza Vickers foi realizado em um microdurômetro Buhler, modelo Micromet 2004, de acordo com a norma ASTM E 384-16 (79), utilizando carga de $50 \mathrm{~g} \mathrm{e}$ tempo de aplicação de $15 \mathrm{~s}$. Em cada amostra foram realizadas 15 medidas ao longo da superfície. 


\section{RESULTADOS E DISCUSSÃO}

Neste texto foram adotadas siglas para fazer referência a cada amostra. Essas siglas serão compostas por duas ou três partes, sendo para as amostras laminadas e amostras recozidas, respectivamente.

A primeira parte faz referência ao grão e é a letra que designa ele. A segunda parte é referente ao tipo da laminação sendo LD e LC para laminação direta e laminação cruzada, respectivamente. A terceira parte é a temperatura do recozimento expressa em graus Celsius, mantido um tempo de recozimento constante de $60 \mathrm{~min}$.

Dois exemplos de utilização das siglas são mostrados a seguir:

- GA-LD: grão A laminado de forma direta até 70\% de redução de espessura;

- GD-LC-1000: grão D laminado de forma cruzada até 70\% de redução de espessura e recozido em $1000^{\circ} \mathrm{C}$ por $60 \mathrm{~min}$.

\subsection{Caracterização microestrutural do material no estado inicial}

Uma macrografia do material na condição inicial é mostrada na Figura 5.1. Nesta imagem os contornos de grãos são destacados para uma melhor visualização, os grãos selecionados para o estudo são indicados. A orientação de cada grão de interesse é ilustrada por um cubo, o qual representa a posição da célula unitária do grão. 
Figura 5.1 - Macroestrutura do material inicial: chapa de nióbio indicando os cinco grãos selecionados para o estudo (DL representa a direção que será adotada inicialmente na laminação).

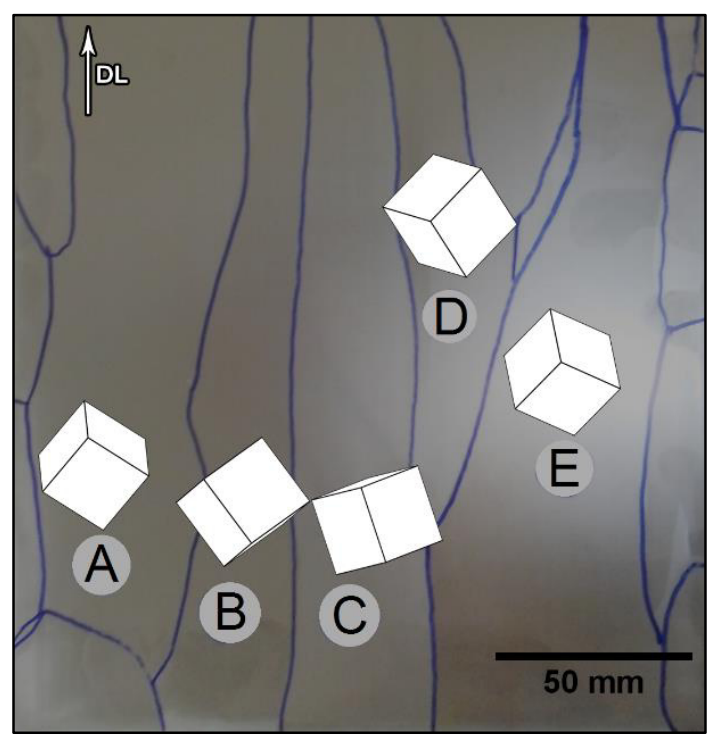

Fonte: a autora.

Os resultados das medidas de orientação inicial dos cinco grãos em estudo são apresentados na Figura 5.2. Nesta imagem são mostrados os mapeamentos de orientações (OIM), as figuras de polo e as prováveis orientações iniciais dos cinco grãos selecionados. O espalhamento ao redor das orientações, presentes nas OIM, varia de um grão para outro, refletindo as dificuldades encontradas na preparação metalográfica, em especial no polimento. Para fins da determinação da orientação inicial de cada grão, este efeito é minimizado. 
Figura 5.2 - Mapeamentos de orientações, figuras de polo e orientação inicial dos grãos em estudo.
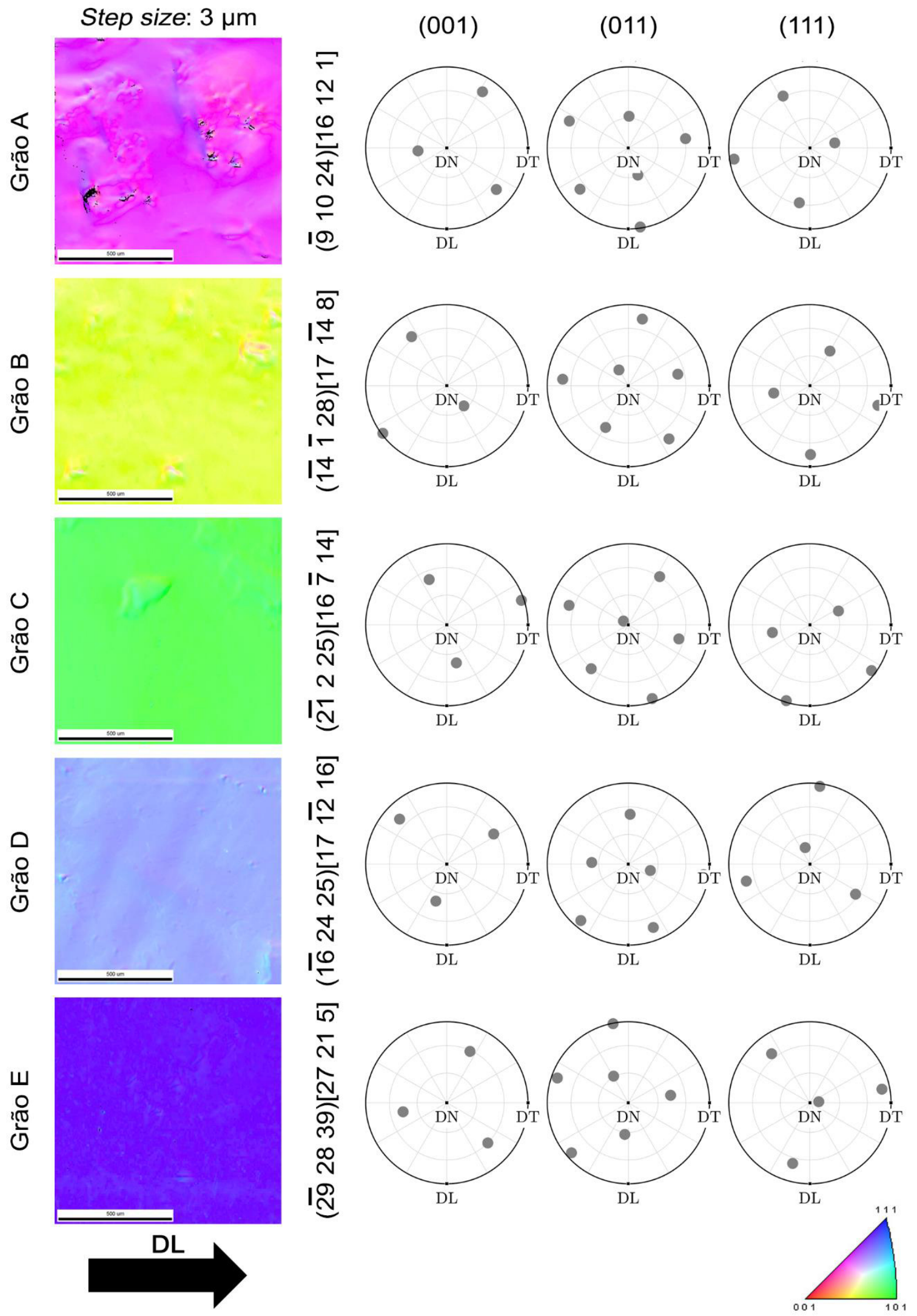

Fonte: a autora. 
As figuras de polo inversa em relação à direção de laminação e em relação à direção normal são mostradas na Figura 5.3. Esta representação explica melhor o fluxo anisotrópico e o comportamento mecânico diferente apresentado pelos grãos $A$ e E. Estes grãos são orientados com o plano paralelo à direção normal perto da fibra (001) - (111) e os planos paralelos à direção de laminação inicial perto do vértice (011) do triângulo. Ele caracteriza suas orientações na textura da fibra alfa, geralmente verificada na laminação a frio de monocristais e policristais com estrutura cúbica de corpo centrado $(4,74)$. Os outros grãos apresentam polos no meio do triângulo e são orientações não estáveis de laminação.

Figura 5.3 - Figuras de polo inversa mostrando a orientação dos grãos em relação à DL e DN.

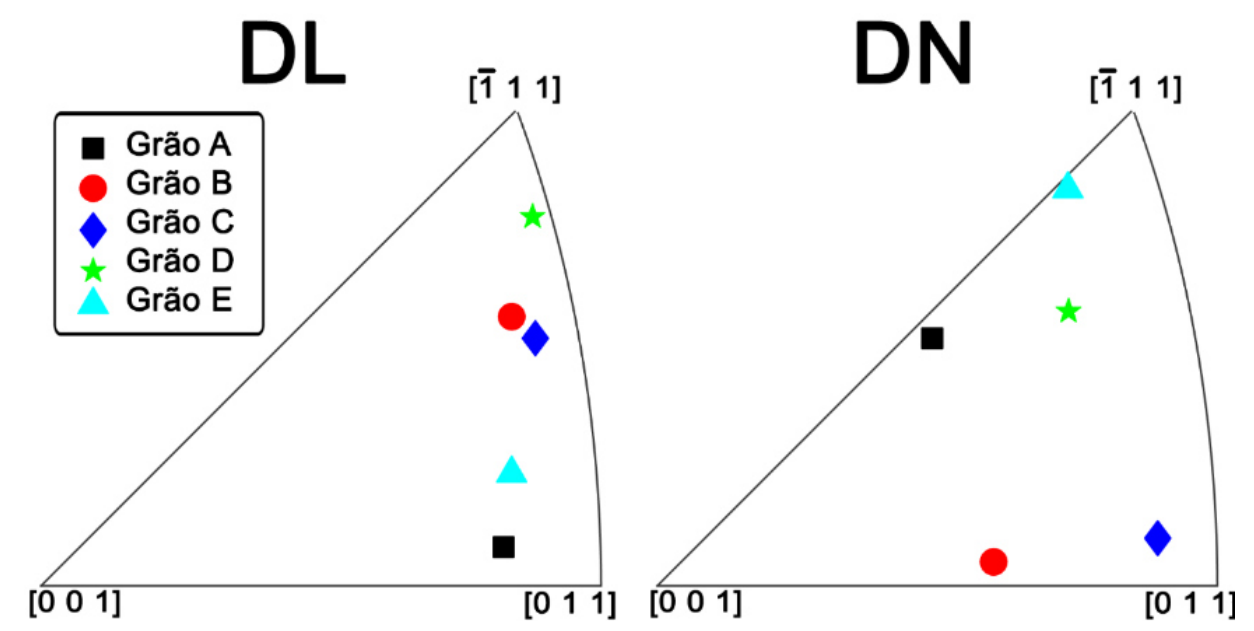

Fonte: a autora.

\subsection{Caracterização do material laminado a frio}

A Figura 5.4 mostra a chapa laminada até $70 \%$ de redução de espessura de forma direta e cruzada. Os contornos dos grãos foram realçados para uma melhor imagem. A deformação da chapa durante a laminação a frio ocorre de forma heterogênea. Um dos fatores que causa isto é o atrito entre os rolos e a chapa. Outro fator é que o material apresenta grãos grosseiros, sujeitos à fragmentação por meio da formação de bandas de transição e de deformação, tornando a deformação macroscópica da chapa e a amostragem bastante heterogêneas, sendo este o fator de maior impacto neste caso. 
Figura 5.4 - Macrografias evidenciando a variação na morfologia dos grãos nas chapas laminadas a frio até $70 \%$ de redução de espessura: (a) direta; (b) cruzada.

(a)

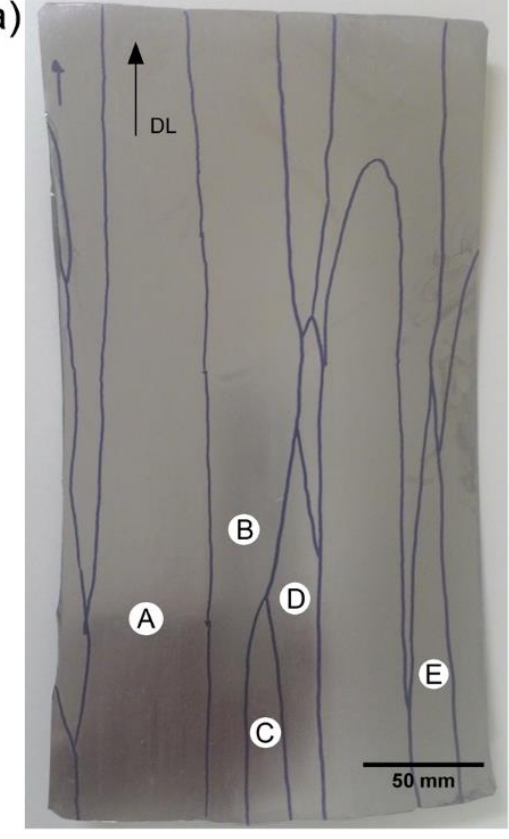

(b)

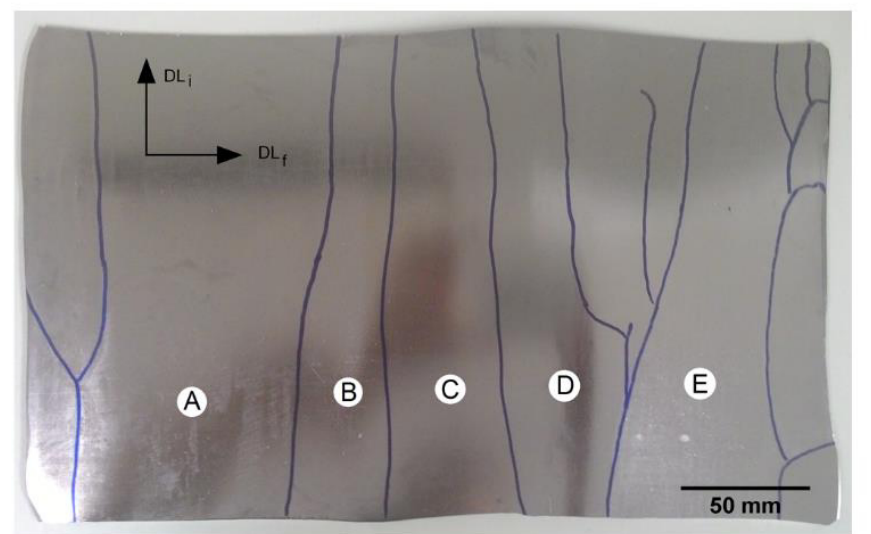

Fonte: a autora.

Os valores de dureza Vickers para o material inicial e deformado são apresentados na Tabela 5.1. Como falado anteriormente o ensaio de dureza Vickers não foi realizado nas amostras laminadas até $70 \%$ de forma direta devido ao empenamento da chapa. Para uma melhor visualização da evolução da dureza durante o encruamento dos grãos, estes foram mostrados no gráfico apresentado na Figura 5.5 (apenas para o ensaio de microdureza Vickers).

Os grãos na condição inicial apresentam valores de dureza próximos, variando de 45 até 52 HV-0,05. Após a laminação até $50 \%$ os grãos B, C, e D apresentam um incremento similar na dureza, que varia de 24 até $28 \%$ de ganho em dureza. Porém, o grão E apresentou um ganho em dureza de $52 \%$. Os grãos $B, C, D$ e E apresentam pouca variação nos valores de dureza, entre a laminação de $50 \%$ e $70 \%$, seja ela na forma direta ou cruzada. O grão A após a laminação é o que apresentou a maior heterogeneidade de deformação sendo a amostra dividida em grandes bandas de deformação. Por isso ele apresenta dois valores médios de dureza, pois os valores variam conforme a banda, porque algumas tiveram um maior acúmulo de deformação que outras. Devido ao grão $A$ apresentar dois valores de dureza para cada condição de laminação, os seus valores são plotados separados dos demais grãos. Alguns grãos possuem um menor valor de dureza após a laminação de $70 \%$, comparado com o de $50 \%$, porém, devido à barra 
de erro não é possível dizer que os valores são menores e sim estatisticamente iguais. Embora a diferença na maior parte dos casos entre os valores de dureza da laminação direta e cruzada sejam muito próximos ou praticamente iguais devido à barra de erro, os valores das amostras de forma direta são sempre maiores dos que as amostras laminadas de forma cruzada.

Tabela 5.1 - Valores de macro e microdureza Vickers em cada grão do material inicial, laminado até $50 \%$ e laminado até $70 \%$.

\begin{tabular}{|c|c|c|c|c|c|c|}
\hline & & Grão & Inicial & $50 \%$ & $70 \%$ direto & $70 \%$ cruzada \\
\hline \multirow{5}{*}{ 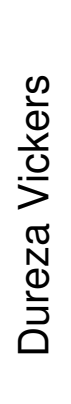 } & \multirow{5}{*}{ 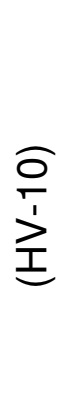 } & $A$ & $46 \pm 2$ & $101 \pm 7$ & - & $66 \pm 2$ \\
\hline & & B & $58 \pm 3$ & $68 \pm 1$ & - & $70 \pm 2$ \\
\hline & & C & $58 \pm 3$ & $78 \pm 3$ & - & $81 \pm 6$ \\
\hline & & D & $58 \pm 2$ & $71 \pm 1$ & - & $69 \pm 3$ \\
\hline & & $E$ & $48 \pm 2$ & $101 \pm 4$ & - & $116 \pm 5$ \\
\hline \multirow{6}{*}{ 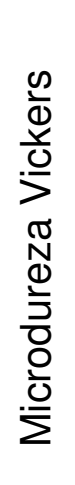 } & \multirow{6}{*}{$\begin{array}{l}0 \\
0 \\
0 \\
0 \\
\stackrel{1}{1} \\
\stackrel{1}{1}\end{array}$} & & & $72 \pm 1$ & $76 \pm 1$ & $70 \pm 6$ \\
\hline & & H & 4514 & $94 \pm 3$ & $108 \pm 3$ & $104 \pm 7$ \\
\hline & & B & $48 \pm 4$ & $66 \pm 2$ & $67 \pm 2$ & $65 \pm 2$ \\
\hline & & C & $50 \pm 4$ & $69 \pm 1$ & $75 \pm 1$ & $70 \pm 2$ \\
\hline & & D & $52 \pm 4$ & $69 \pm 2$ & $72 \pm 1$ & $66 \pm 6$ \\
\hline & & $E$ & $45 \pm 2$ & $94 \pm 3$ & $100 \pm 3$ & $94 \pm 3$ \\
\hline
\end{tabular}

Fonte: a autora. 
Figura 5.5 - Relação entre a microdureza Vickers e a deformação verdadeira para as amostras laminadas: (a) grão A; (b) grão B, C, D e E.

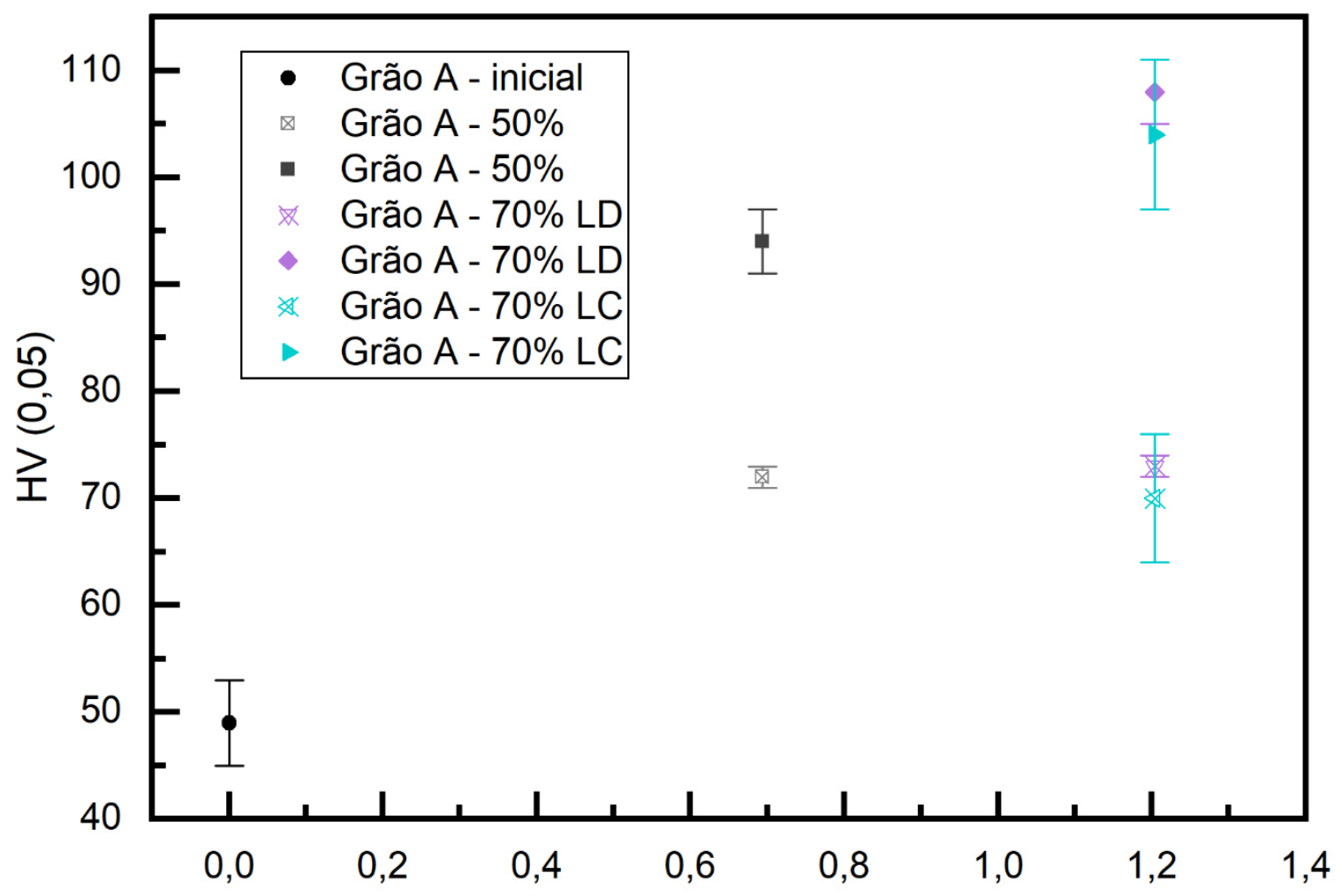

(a)

$\varepsilon$

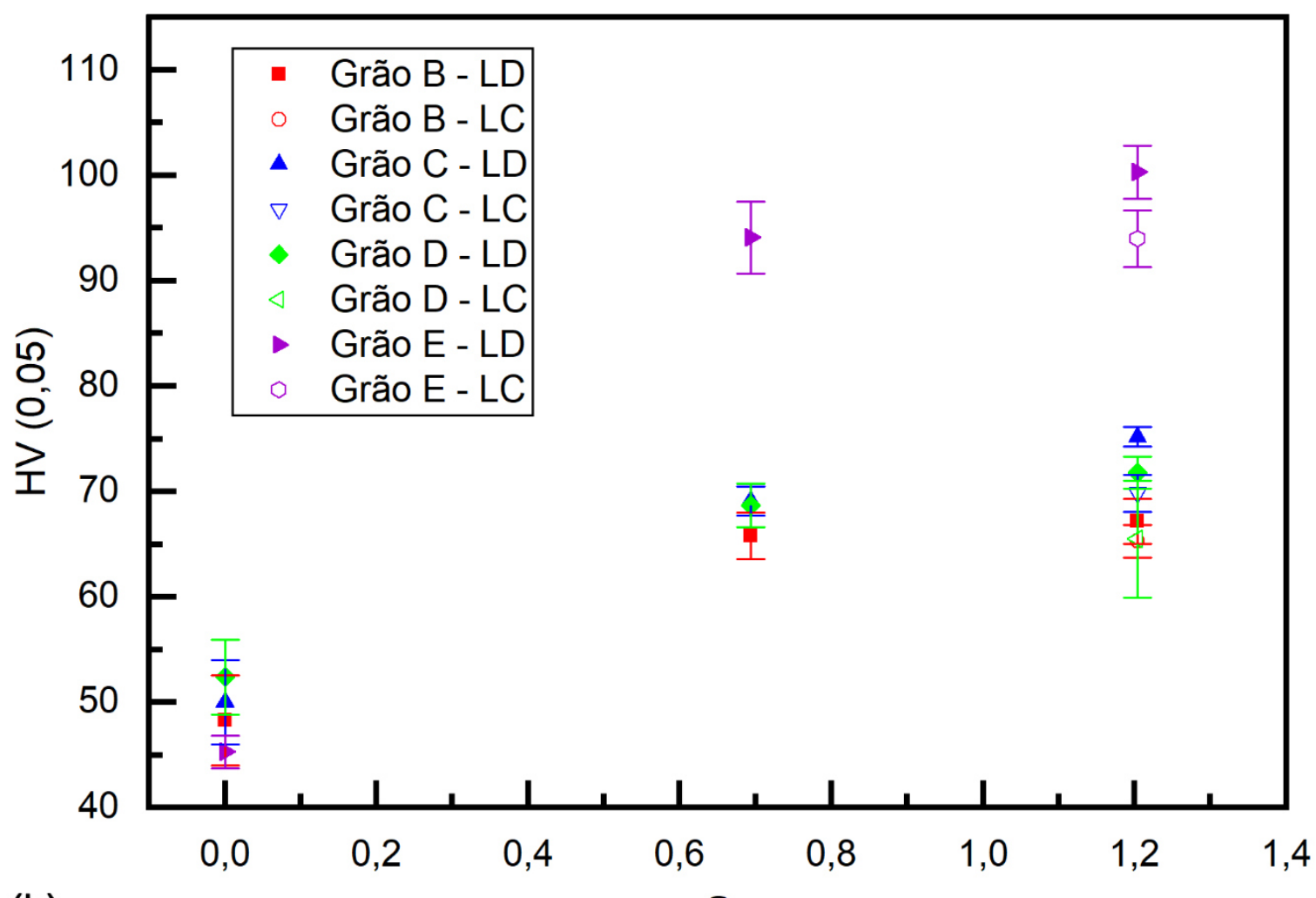

(b)

$\varepsilon$

Fonte: a autora. 
Como discutido na revisão da literatura, a deformação pode ser dividida em duas escalas, micro e macro. Na escala microscópica são formadas discordâncias e células de discordâncias, as quais podem ser vistas na Figura 5.6, a qual mostra detalhes da microestrutura da amostra E-LC. No centro da Figura 5.6 (a) a região clara é uma célula de discordância, a qual é formada no nióbio em temperatura ambiente, pois é um metal de alta EDE, favorecendo a recuperação dinâmica do material. Na Figura 5.6 (b) a célula de discordância é a região escura e é possível visualizar as discordâncias presentes no interior da célula, as quais são chamadas de discordâncias incidentais (ID, do inglês, incidental dislocations) $(4,12,33,80)$. Como essas estruturas são formadas na temperatura ambiente elas tem um grau de aperfeiçoamento bem menor quando comparadas com um subgrãos, que são formados em maiores temperaturas, tendo assim as discordâncias uma maior mobilidade.

Macroscopicamente algumas das mudanças são a formação das bandas de deformação e transição. A Figura 5.7 mostra em detalhes as bandas de deformação e transição presentes na amostra A-LD. O grão é completamente subdividido. Algumas bandas têm mais de $10 \mathrm{~mm}$ de comprimento, enquanto outras são mais estreitas. A diferença de orientação entre as bandas pode ser maior que $15^{\circ}$, em alguns casos atingindo valores bem maiores, levando assim à formação de contornos de alto ângulo no interior do grão original. Esses contornos são regiões de maior energia acumulada e atuam como locais preferenciais para a nucleação da recristalização $(11,12)$. A formação de bandas é comum em materiais com grãos grosseiros, como é o caso nesse trabalho, onde os grãos têm tamanho da ordem de centímetros. Tanto micro como macroscopicamente, ocorreu um grande refinamento microestrutural nas amostras. 
Figura 5.6 - Micrografia mostrando a amostra E-LC (MEV-FEG), a DL final é paralela à barra de escala.
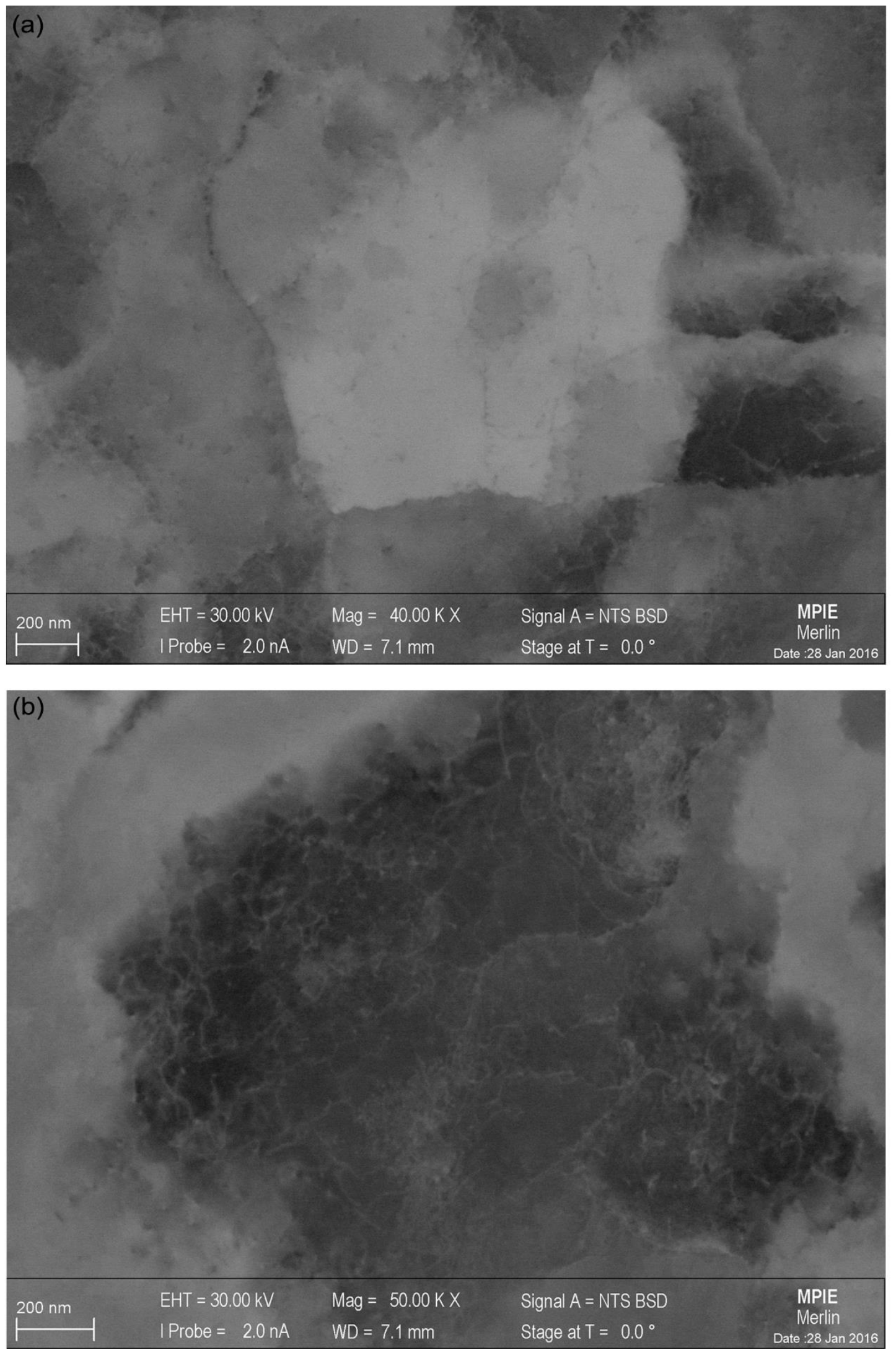

Fonte: a autora. 
Figura 5.7 - Macrografia do A-LD evidenciando a estrutura fortemente bandeada.

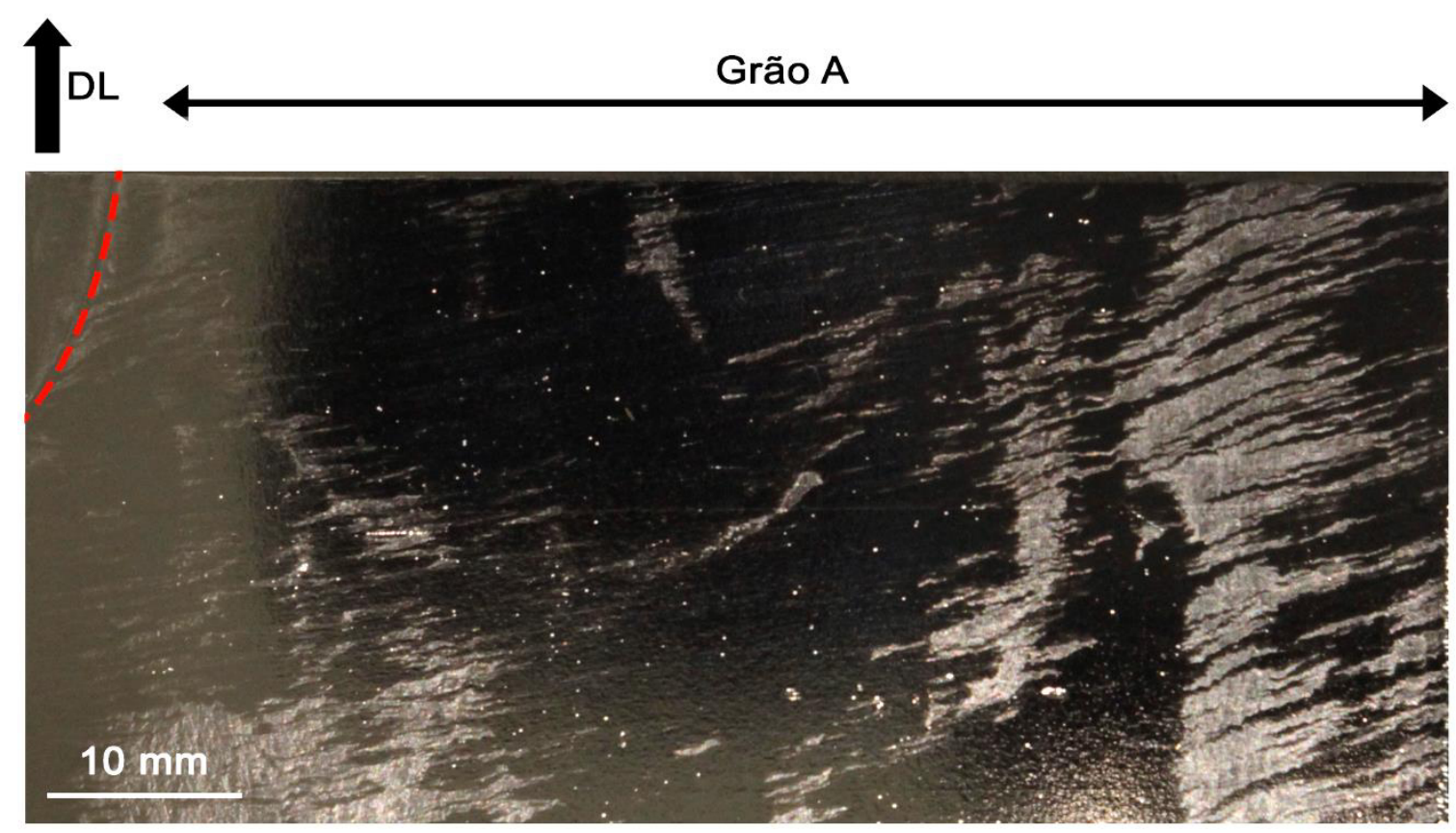

Fonte: a autora.

A amostra A laminada tem uma estrutura fortemente bandeada e como visto nos resultados de dureza Vickers, ocorrem grandes variações conforme se muda de uma banda para outra na amostra. Isto vai afetar os resultados obtidos nas amostras recozidas, como será visto no decorrer do trabalho, pois algumas bandas acumularam mais energia recristalizando mais facilmente que outras que acumularam menos energia.

Os mapeamentos de orientações das amostras A-LD, A-LC, E-LD, E-LC são apresentados na Figura 5.8. As suas respectivas figuras de polo são apresentadas na Figura 5.9, onde os pontos cinzas correspondem a amostra na condição inicial. A amostra E-LD apresenta um maior desvio da inicial, comparada com a E-LC. A desorientação média da amostra E-LD com a amostra inicial é de $46^{\circ}$, e para a amostra E-LC a desorientação é de $31^{\circ}$. A amostra A-LC tem orientação cubo girado, a qual tem um fator de Taylor muito baixo, tendo assim uma baixa tendência a formação de núcleo de recristalização (73). Porém, como essa amostra é subdividida em várias bandas, e a região que as amostras foram retiradas variam, algumas amostras foram retiradas da região com orientação cubo girado, e outras não, o que vai resultar em algumas amostras recristalizadas e outras apenas recuperadas. Vandermeer e Snyder mostraram que um monocristal com a orientação de cubo girado não recristalizou mesmo quando recozido em 
$1200^{\circ} \mathrm{C}$ (81). A região mapeada da amostra E-LC (Figura 5.8 (d)) mostra uma banda de transição, onde estão alinhados os grãos em verde, durante o recozimento desta amostra, essas regiões atuam como locais preferenciais para a nucleação da recristalização.

Figura 5.8 - Mapeamento das orientações das amostras laminadas até 70\%: (a) A-LD; (b) A-LC; (c) E-LD; (d) E-LC.
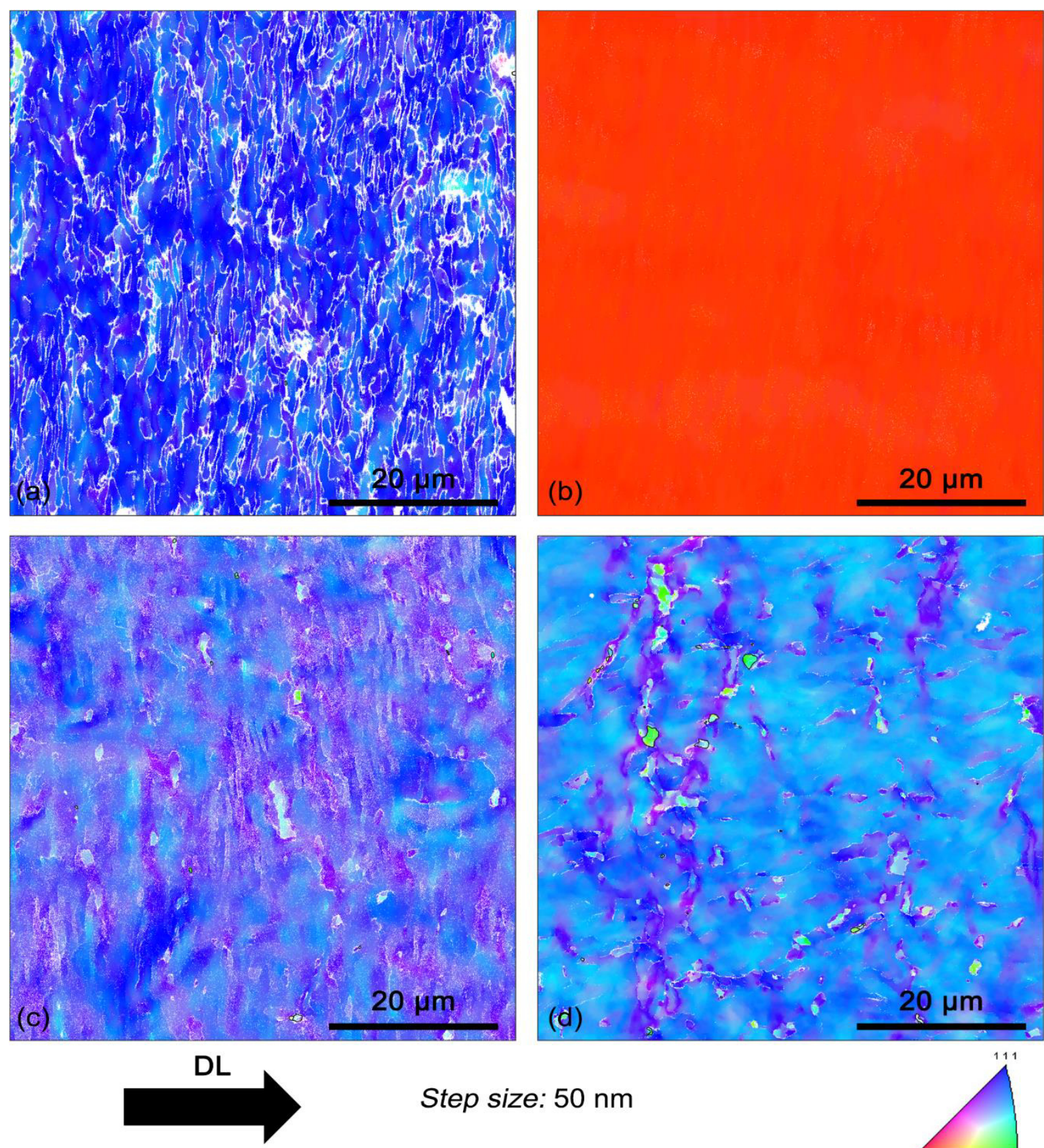

Step size: $50 \mathrm{~nm}$

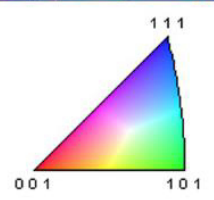

Fonte: a autora. 
Figura 5.9 - Figuras de polo dos grãos A e E laminados até $70 \%$. Os pontos cinzas correspondem a amostra na condição inicial.

(111)
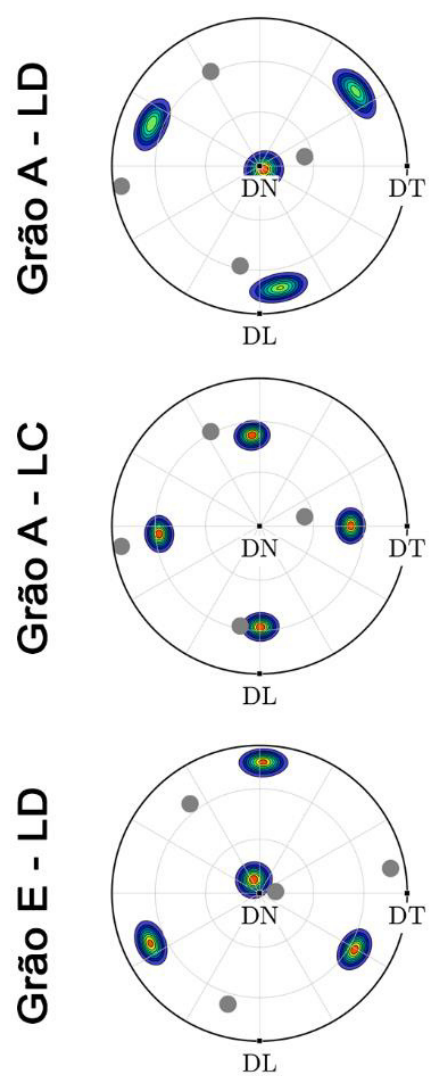

ש

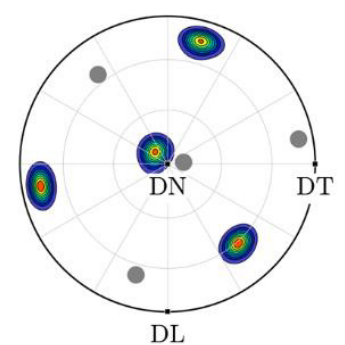

(011)
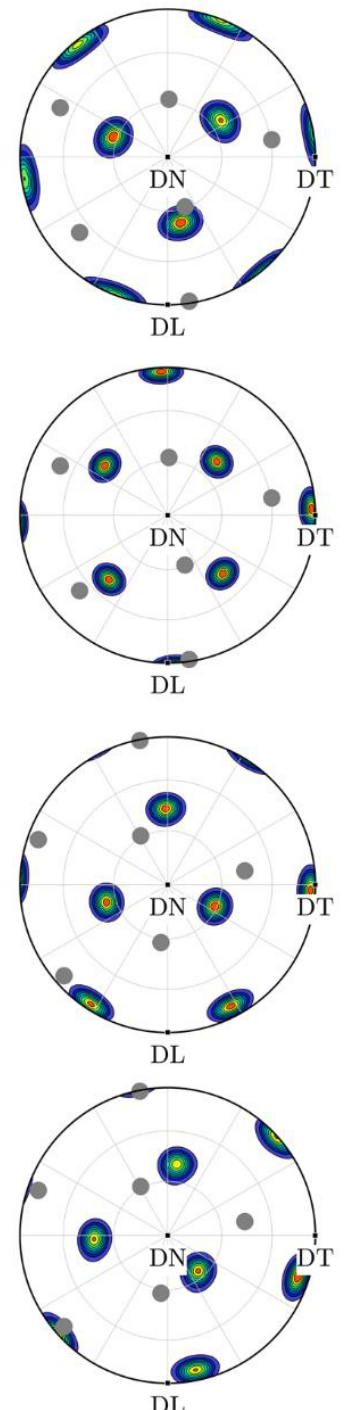

(112)
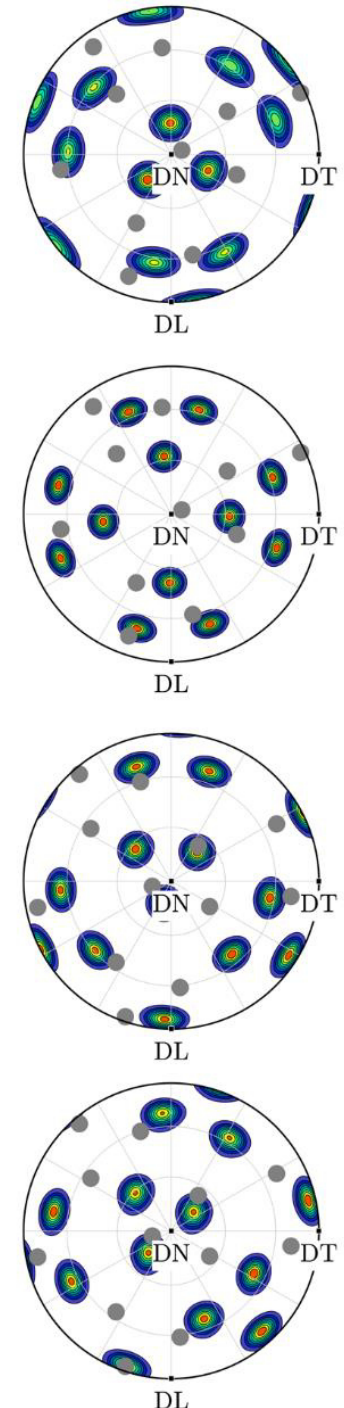

(123)
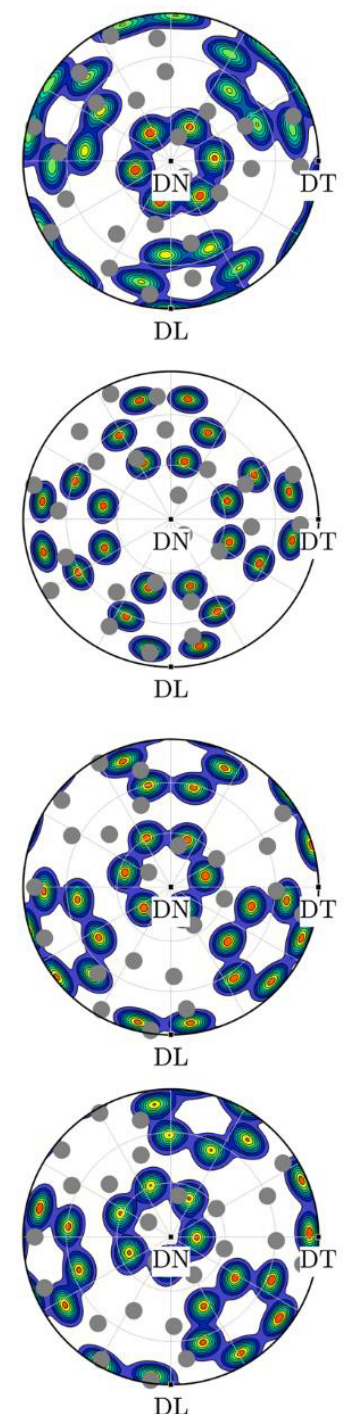

Fonte: a autora.

Os mapas de mesotextura das amostras A-LD, E-LD e E-LC são mostrados na Figura 5.10, onde os contornos de alto ângulo $\left(\geq 15^{\circ}\right)$ são marcados em preto e os de baixo ângulo $\left(<15^{\circ}\right)$ são marcados em vermelho. A amostra A-LC não apresenta diferença de orientação maior que $2^{\circ}$ na área mapeada, por este motivo não foi gerado o mapa de mesotextura para esta amostra. A amostra A-LD é a que apresenta a maior quantidade de contornos, tendo a estrutura finamente fragmentada. A amostra E-LD apresenta pequenos pontos no mapeamento os quais provavelmente são defeitos oriundos do polimento. A banda de transição presente na amostra E-LC é melhor visualizada neste mapa (Figura 5.10 (c)), no 
interior da banda tem regiões que apresentam contornos de alto. A fração de contornos de alto ângulo é de $0,6 \%, 0,5 \%$ e $2 \%$ para as amostras A-LD, E-LD e ELC, respectivamente. Os histogramas na Figura 5.11 mostram a desorientação da área mapeada. Essa desorientação é calculada levando em conta a orientação média da área mapeada comparada com cada ponto do mapeamento.

Figura 5.10 - Mapeamento dos contornos de grãos das amostras laminadas até 70\%: (a) A-LD; (b) E-LD; (c) E-LC.

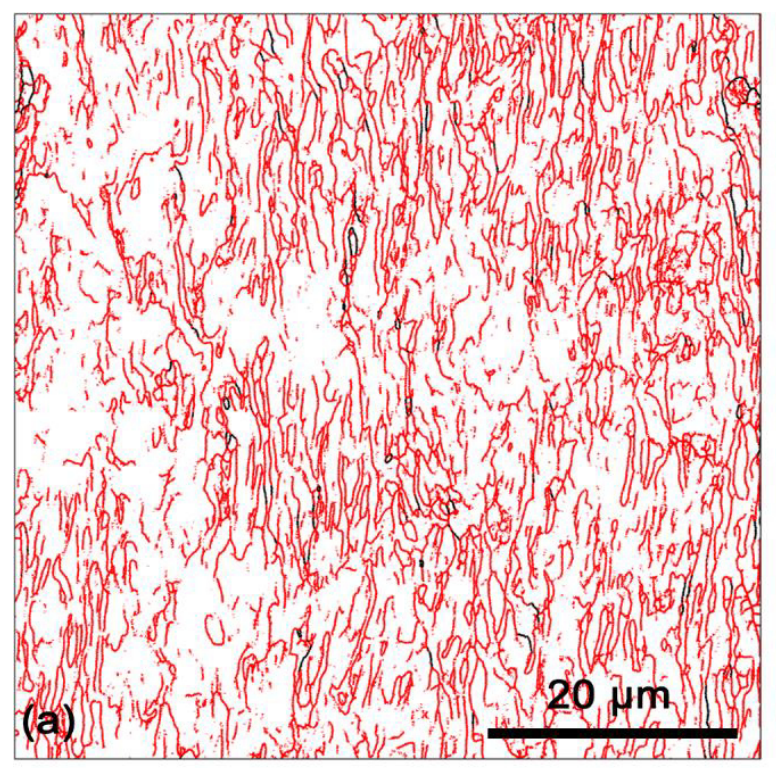

Step size: $50 \mathrm{~nm}$
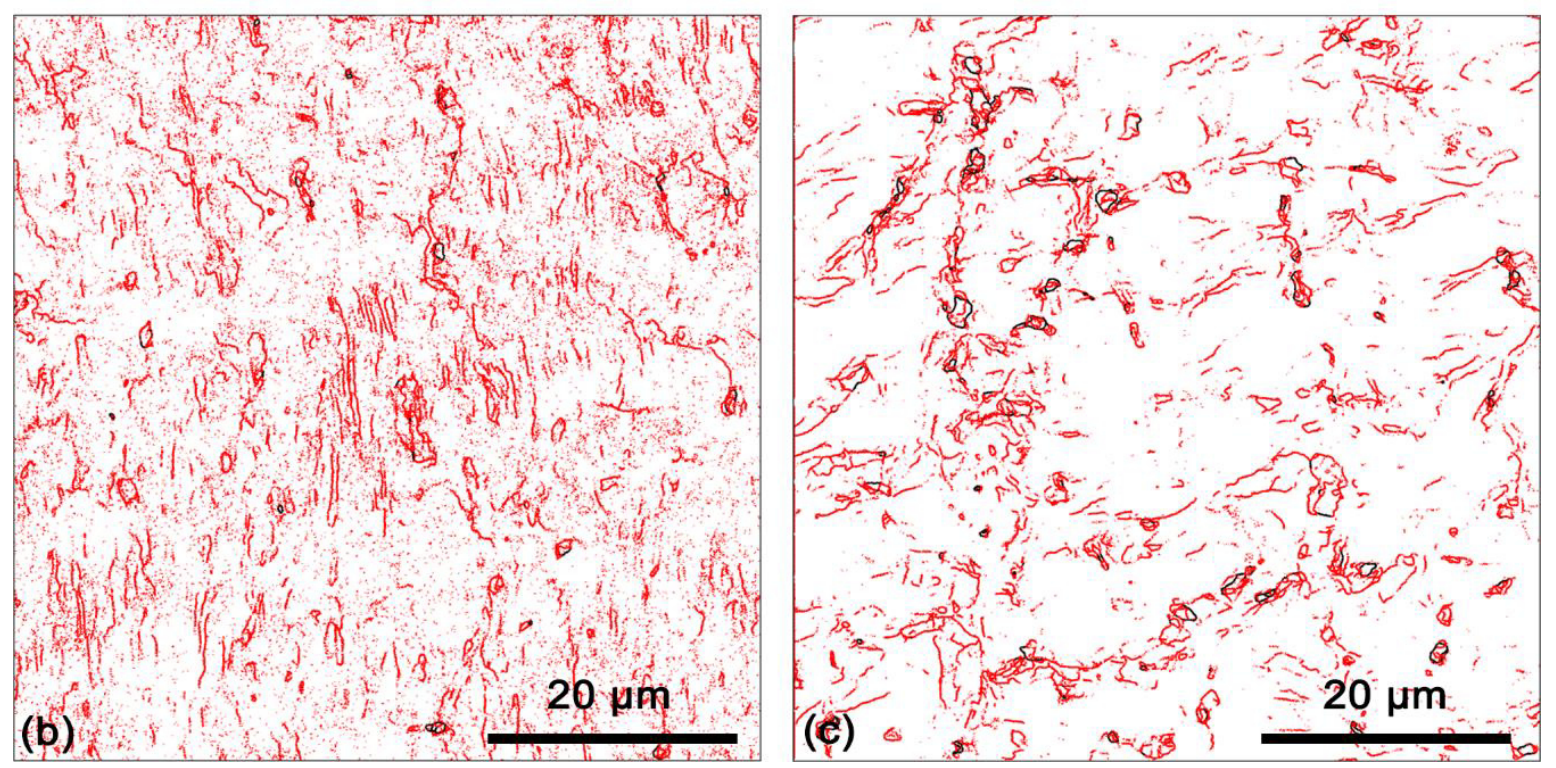

Fonte: a autora. 
Figura 5.11 - Histograma da desorientação no mapeamento das amostras laminadas até $70 \%$ : (a) A-LD; (b) A-LC; (c) E-LD; (d) E-LC.
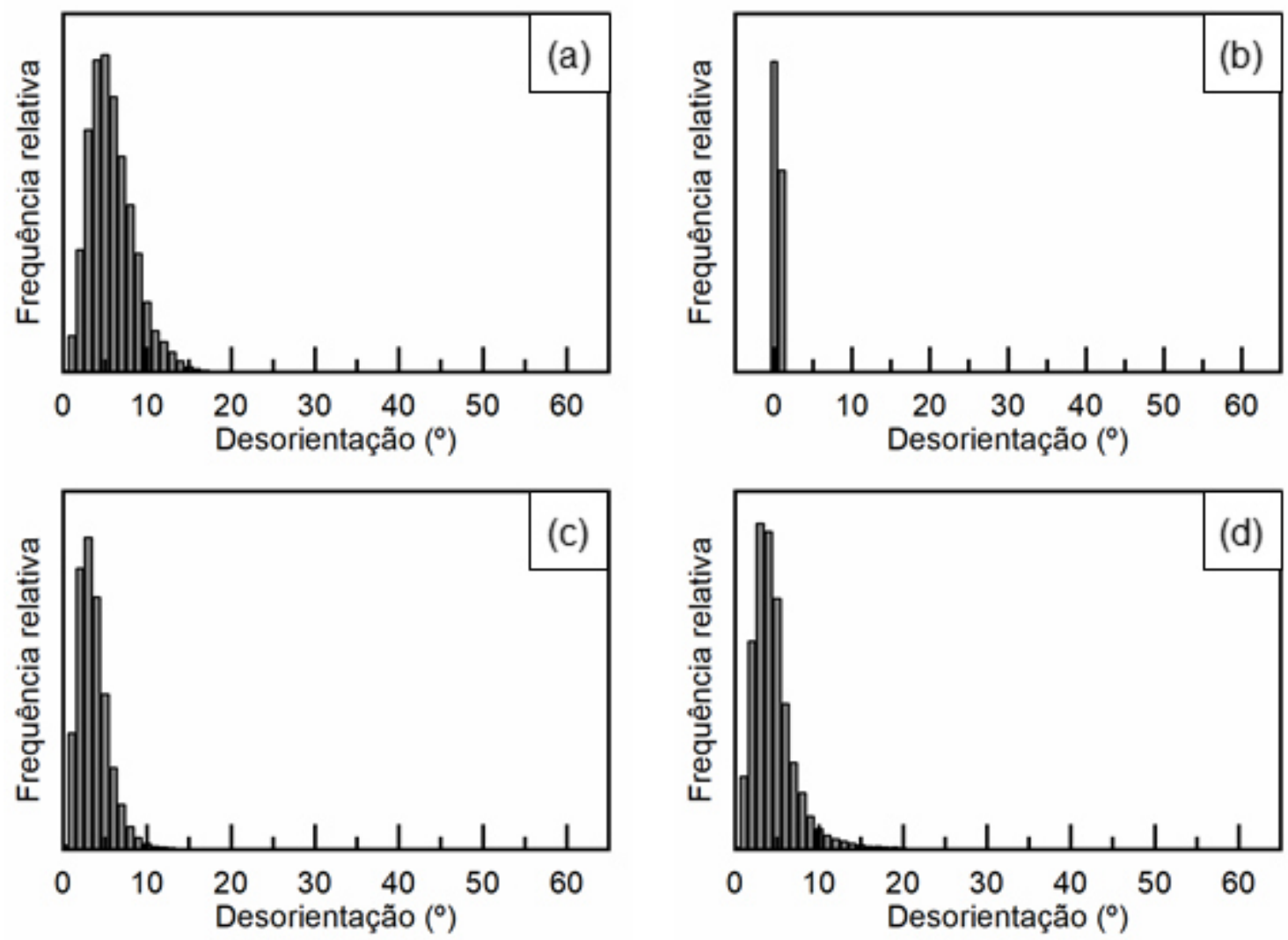

Fonte: a autora.

A Figura 5.12 mostra o gradiente de orientações para as amostras A-LD, A-LC, E-LD e E-LC. A Figura 5.13 mostra os respectivos histogramas destes gradientes de orientações. O cálculo do gradiente de orientação, para cada ponto do mapeamento, foi realizado pelo método desenvolvido por Kamaya (82), onde é realizado o cálculo de KAM (kernel average misorientation) para diferentes tamanhos de núcleos (vizinhos). O máximo tamanho de núcleo utilizado foi de 5 vizinhos. Cada tamanho de núcleo representa uma distância física, assim, os valores de KAM foram plotados em função da distância referente ao tamanho de núcleo e os dados foram linearizados utilizando uma função do tipo y =a.x $+b$. A interseção da linha com o eixo y é considerada como o erro de medida e a inclinação da curva é o gradiente de orientações. A unidade de medida do gradiente de orientação é \%unidade de comprimento, e no caso nesse trabalho \% $/ \mu \mathrm{m}$. As regiões que apresentam um maior gradiente de orientação do que a sua vizinhança, atuam como locais preferenciais para a nucleação da recristalização e também como locais onde a migração dos contornos de grãos recristalizados ocorre com maior facilidade e velocidade (83). 
A amostra A-LD, entre as amostras deformadas mapeadas, é a que apresenta o maior intervalo de gradiente de orientações e uma distribuição uniforme do gradiente pela amostra. $89 \%$ dos pontos apresentam gradientes de orientação menor que $10^{\circ}$ e $58 \%$ menor que $5^{\circ}$. A amostra A-LC além de ter a orientação cubo girado, a qual é estável e não recristaliza com facilidade, tem um gradiente de orientação de no máximo $2^{\circ}$, sendo mais um fator que dificulta a nucleação da recristalização nesta amostra, ou ao menos nas bandas que apresentam esta orientação após a laminação.

Figura 5.12 - Gradiente de orientação $(\% / \mu \mathrm{m})$ representada na escala de intensidades em anexo: (a) A-LD; (b) A-LC; (c) E-LD; (d) E-LC.
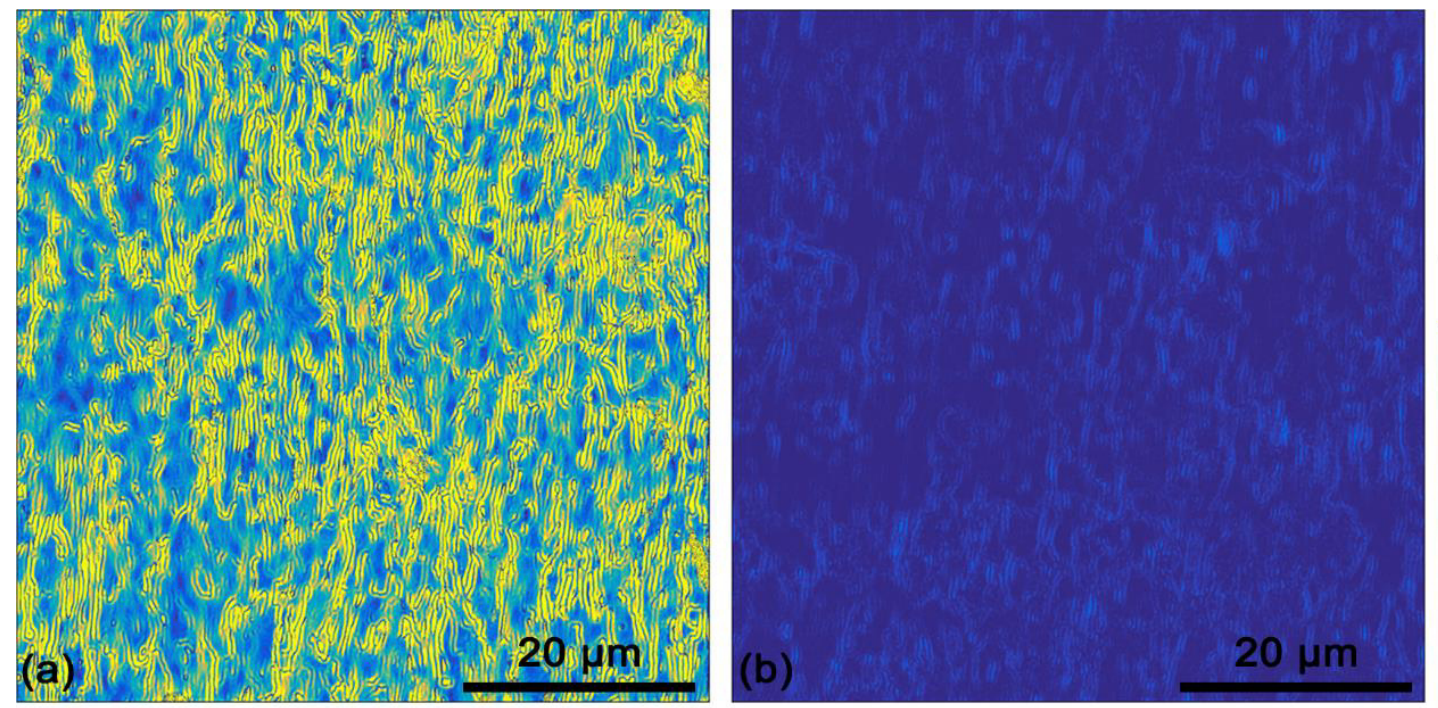

$\% \mathrm{~mm}$
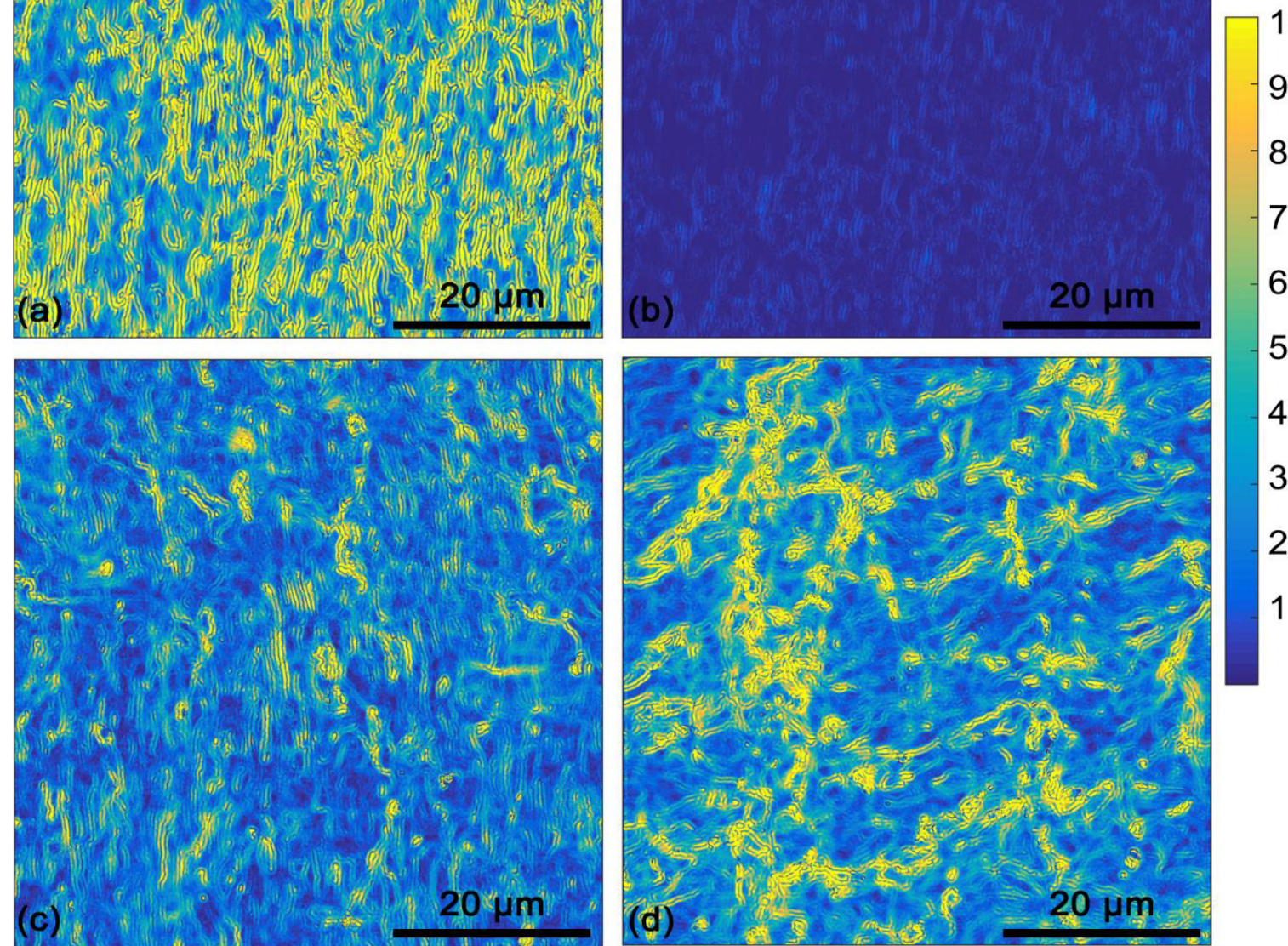

DL

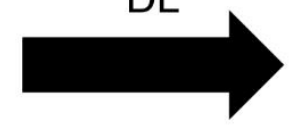

Step size: $50 \mathrm{~nm}$

Fonte: a autora. 
Para a amostra do grão $E$ laminada de forma direta, além de apresentar uma menor variação no gradiente de orientações, apresenta uma distribuição mais homogênea comparada a outra amostra. A amostra laminada de forma cruzada apresenta uma distribuição do gradiente de orientações bem heterogênea, em partes pela formação de bandas de transição, onde são associadas maiores variações na orientação. Na amostra E-LD 99\% dos pontos apresentam gradientes de orientação menor que $10^{\circ}$ e $91 \%$ menor que $5^{\circ}$. Já para a amostra E-LC $96 \%$ dos pontos apresentam gradientes de orientação menor que $10^{\circ}$ e $79 \%$ menor que $5^{\circ}$, possuindo assim uma maior heterogeneidade comparado a outra amostra. Essas regiões além de serem locais propícios para a nucleação da recristalização, também são regiões onde ela ocorre com maior velocidade.

Figura 5.13 - Histogramas dos gradientes de orientação: (a) A-LD; (b) A-LC; (c) E-LD; (d) E-LC.
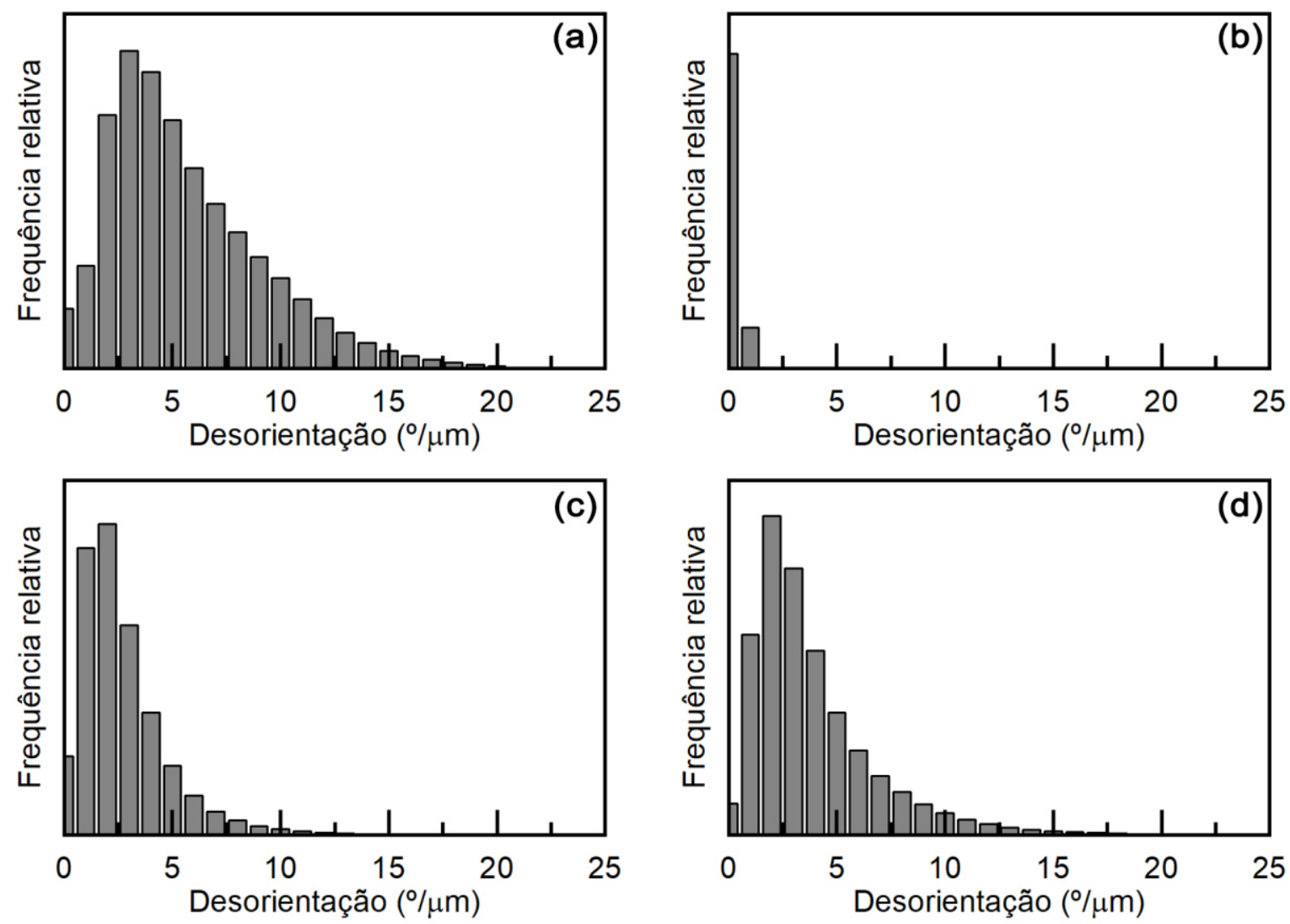

Fonte: a autora.

As regiões denominadas embriões ou núcleos de recristalização são formadas durante a deformação (saturação de sítios) do material e não no posterior recozimento (nucleação com taxa constante) (22). Como forma de determinar onde estariam os possíveis núcleos de recristalização nas amostras laminadas de forma 
direta e cruzada nos grãos A e E, nos mapeamentos de EBSD foram encontradas as regiões as quais estavam associadas com contornos de alto ângulo $\left(>15^{\circ}\right)$ e possuíam GOS (grain orientation spread) menor que $2^{\circ}$. O objetivo deste mapa é analisar a desorientação dos núcleos com relação à matriz e também a forma com a qual eles se distribuem na microestrutura. Os mapas das desorientações dos núcleos com a matriz são mostrados na Figura 5.14. Eles foram gerados utilizando a desorientação ponto a ponto desta área com a orientação média dos núcleos para cada amostra (neste mapa os núcleos são representados em branco). Na amostra A-LC, não se observa diferença de orientação menor que $2^{\circ}$ na área mapeada. Sendo assim, pelos critérios escolhidos, não foi possível analisar os núcleos presentes nesta condição. Na amostra E-LC a maior parte dos núcleos estão presentes na banda de transição, o que levará a uma recristalização não-uniforme. Os histogramas de desorientação destes mapas são dados na Figura 5.15. A desorientação média entre o núcleo e a matriz recuperada adjacente é de $11^{\circ}, 38^{\circ}$ e $45^{\circ}$ para as amostras A-LD, E-LD e E-LC, respectivamente. Como discutido anteriormente, a forma como os defeitos estão distribuídos na amostra tem grande influência na microestrutura formada após o recozimento e a amostra laminada de forma cruzada, além do maior valor médio, apresenta um intervalo maior de desorientação. A forma que isso está distribuído na amostra pode levar a caminhos preferenciais para que a recristalização ocorra, isto tanto em nível macro, onde a recristalização ocorre de forma bastante heterogênea na amostra, e também em nível microscópico onde essas diferenças levam à formação de ondulações nos contornos dos grãos recristalizados. Pois, mesmo para dois grãos que tenham quantidade de energia armazenada semelhantes, se a forma na qual a energia estiver distribuída for diferente, isso pode levar à formação de protrusões com formatos, tamanhos e frequências diferentes. 
Figura 5.14 - Mapeamento da desorientação da matriz com os prováveis núcleos de recristalização das amostras laminadas até 70\% para as amostras: (a) A-LD; (b) E-LD; (c) E-LC.
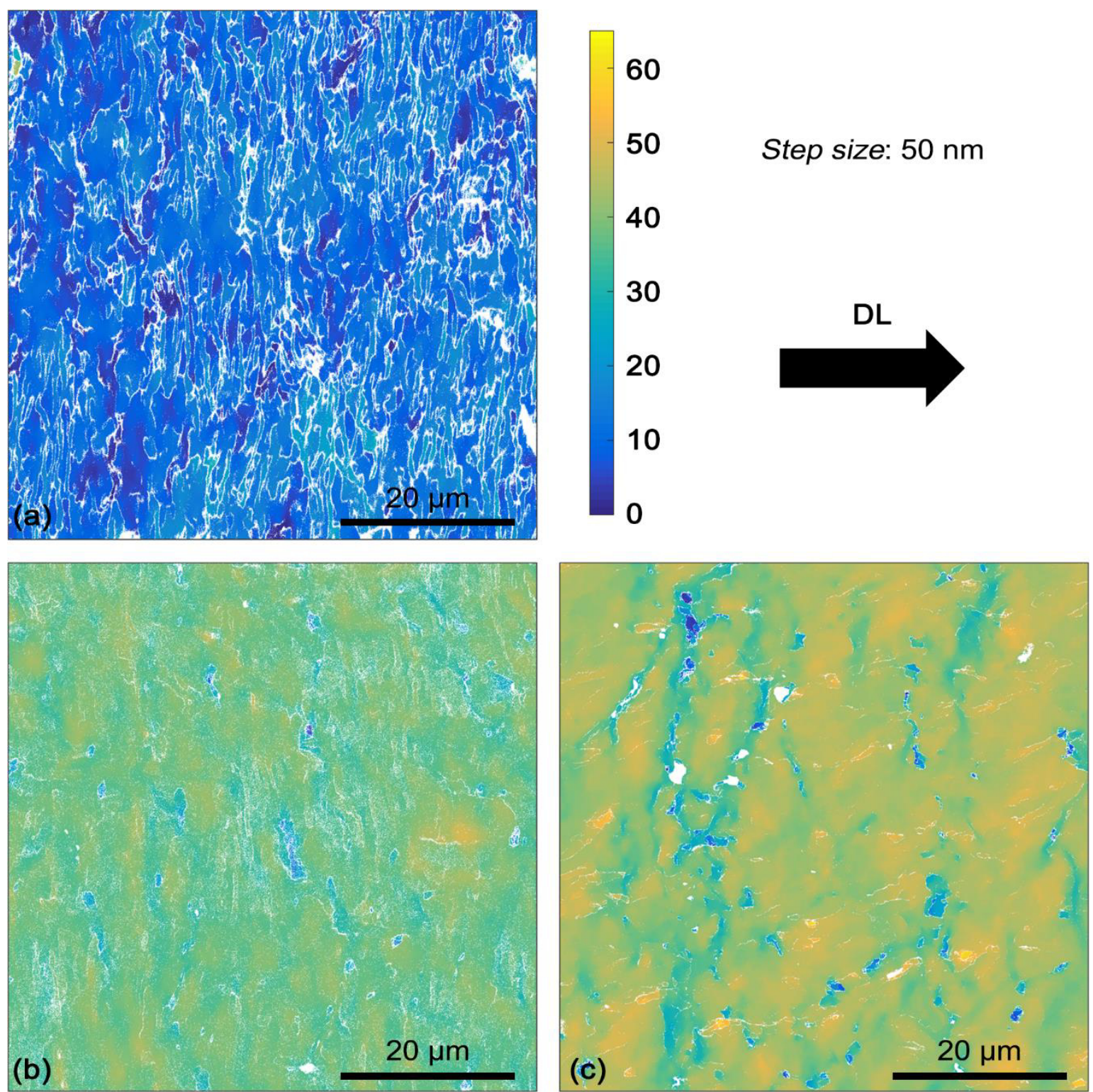

Fonte: a autora. 
Figura 5.15 - Histograma da desorientação da matriz com os prováveis núcleos de recristalização das amostras laminadas até 70\% das amostras: (a) A-LD; (b) E-LD; (c) E-LC.

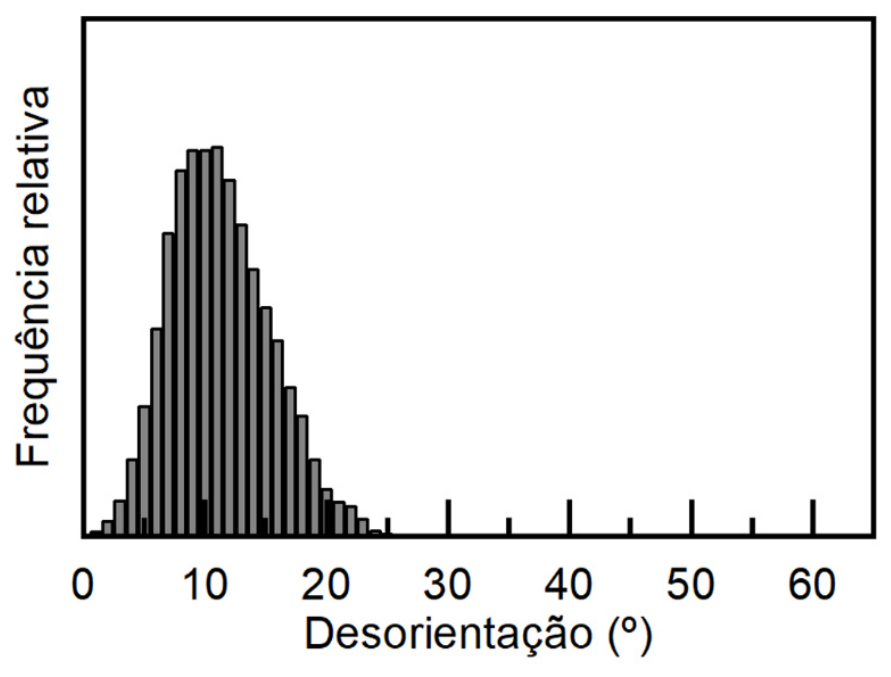

(a)

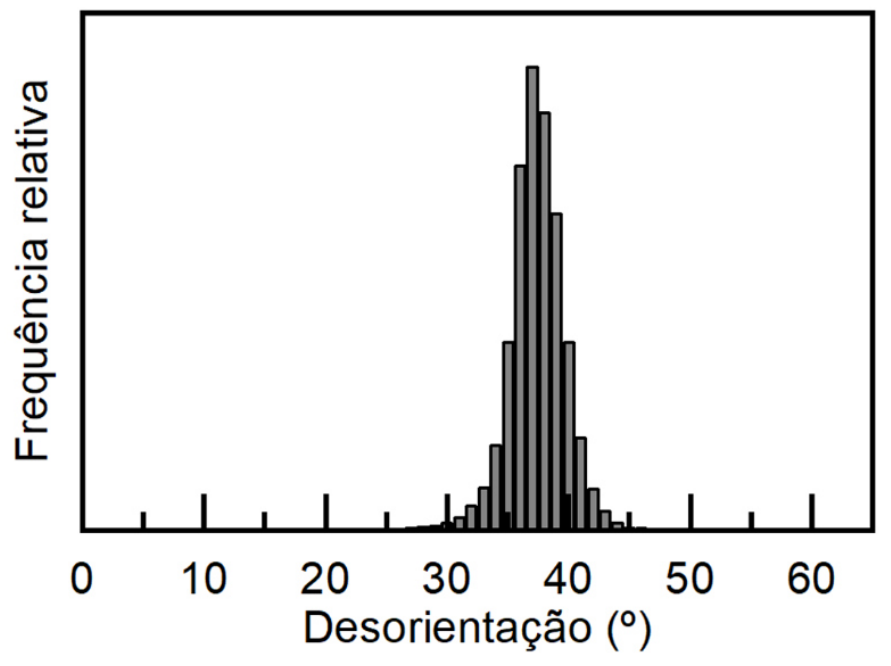

(b)

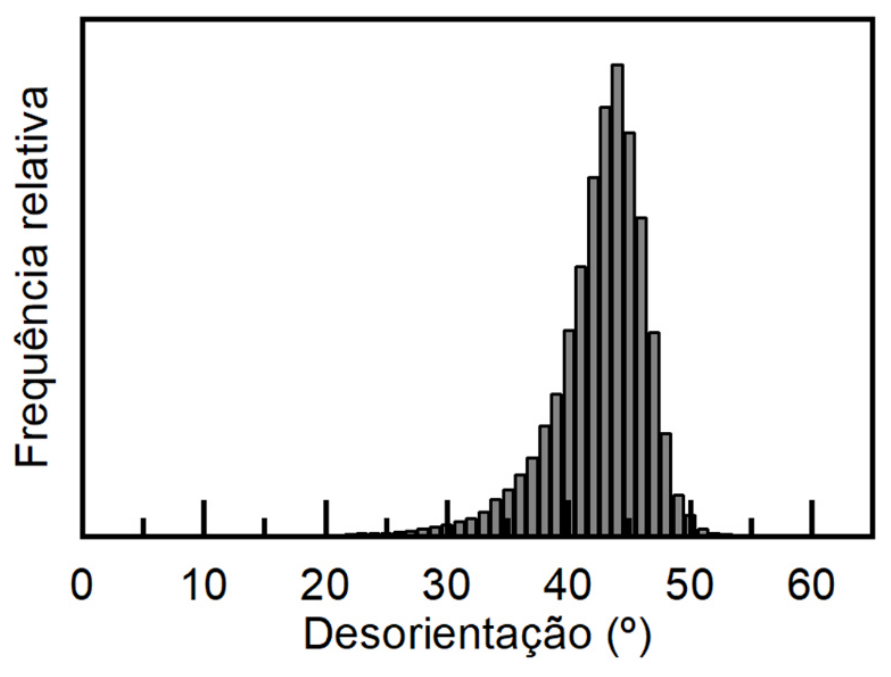

Fonte: a autora. 


\subsection{Caracterização do material recozido}

A Tabela 5.2 é um resumo da condição encontrada em cada amostra após o recozimento isotérmico. A sigla RV é utilizada para amostras onde a recristalização não foi observada, isto é, as amostras apenas recuperaram, enquanto que $\mathrm{RX}$ indica as amostras onde ocorreu a recristalização (parcial ou total). A maioria dos resultados aborda os grãos $\mathrm{A}$ e $\mathrm{E}$, pois, foram os únicos que recristalizaram na maior parte das temperaturas de estudo. Essa diferença de seu comportamento de recozimento (nucleação, cinética e textura de recristalização) mostra a influência da orientação e do modo de deformação, com predominância do primeiro fator, pois alguns grãos recristalizaram e outros não. Os efeitos de orientação se tornam muito mais pronunciados em materiais de grão grosseiro, como nióbio, tântalo e alumínio (15-17,60,81,84-86). Dependendo de sua orientação inicial, alguns grãos desenvolvem microestruturas de deformação muito fragmentadas, enquanto outros grãos se deformam de uma maneira muito mais estável, como a componente de textura de cubo girado $\{001\}<110>$ em metais cúbicos de corpo centrados $(17,60,81,84-86)$.

Tabela 5.2 - Condição metalúrgica das amostras laminadas após o recozimento isotérmico entre 800 e $1200^{\circ} \mathrm{C}$.

\begin{tabular}{|c|c|c|c|c|c|c|}
\hline & Grão & $800^{\circ} \mathrm{C}$ & $900^{\circ} \mathrm{C}$ & $1000^{\circ} \mathrm{C}$ & $1100^{\circ} \mathrm{C}$ & $1200^{\circ} \mathrm{C}$ \\
\hline \multirow{5}{*}{ 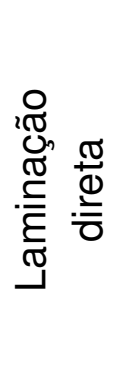 } & $A$ & $\mathrm{RV}$ & $\mathrm{RV}$ & $\mathrm{RV}$ & $\mathrm{RV}$ & $R X$ \\
\hline & B & $\mathrm{RV}$ & $\mathrm{RV}$ & $\mathrm{RV}$ & $\mathrm{RV}$ & $\mathrm{RV}$ \\
\hline & $\mathrm{C}$ & $\mathrm{RV}$ & $\mathrm{RV}$ & $\mathrm{RV}$ & $\mathrm{RV}$ & $\mathrm{RV}$ \\
\hline & $D$ & $\mathrm{RV}$ & $\mathrm{RV}$ & $\mathrm{RV}$ & RV & $\mathrm{RV}$ \\
\hline & $E$ & $\mathrm{RV}$ & $\mathrm{RV}$ & $R X$ & $R X$ & $R X$ \\
\hline \multirow{5}{*}{ 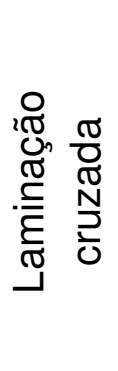 } & $A$ & $\mathrm{RX}$ & $R X$ & $\mathrm{RV}$ & $R X$ & $\mathrm{RX}$ \\
\hline & $B$ & $\mathrm{RV}$ & $\mathrm{RV}$ & $\mathrm{RV}$ & $\mathrm{RV}$ & $\mathrm{RV}$ \\
\hline & C & $\mathrm{RV}$ & $\mathrm{RV}$ & $\mathrm{RV}$ & $\mathrm{RV}$ & $R X$ \\
\hline & $D$ & $\mathrm{RV}$ & $\mathrm{RV}$ & $\mathrm{RV}$ & $\mathrm{RV}$ & $\mathrm{RV}$ \\
\hline & $E$ & $\mathrm{RX}$ & $\mathrm{RX}$ & $R X$ & $\mathrm{RX}$ & $\mathrm{RX}$ \\
\hline
\end{tabular}

Fonte: a autora.

Nota: RV indica as amostras que apenas recuperaram e RX as amostras onde ocorreu a recristalização (parcial ou total). 
As amostras do grão $B$ e $D$ não recristalizam em nenhuma das duas condições de laminação e em nenhuma das temperaturas do estudo. A amostra do grão C laminada de forma direta também não recristalizou em nenhuma temperatura e a laminada de forma cruzada recristalizou apenas em $1200^{\circ} \mathrm{C}$. Essas amostras após a laminação apresentaram apenas um pequeno ganho em dureza. Diversos trabalhos em nióbio e tântalo mostram a influência da orientação inicial do grão na sua deformação e posterior recozimento. Dependendo da orientação inicial dos grãos, diferenças importantes na energia armazenada são observadas afetando o comportamento frente ao recozimento, podendo favorecer a recristalização ou a recuperação (81,86-88).

Materiais com grãos grosseiros são propensos à subdivisão por bandas de deformação $(18,19)$. A formação de bandas de deformação depende da orientação e do tamanho de grão e estas são delimitadas por bandas de transição (18). Nos grãos $A$ e $E$ a formação dessas bandas influenciou a recristalização, já que a nucleação da recristalização ocorreu nas bandas de transição, especialmente nas amostras laminadas de forma cruzada.

As Figura 5.16 (a), (b) e (c) são micrografias com baixa ampliação da amostra E-LC e tratado termicamente por $60 \mathrm{~min}$ em $800^{\circ} \mathrm{C}, 900^{\circ} \mathrm{C}$ e $1000^{\circ} \mathrm{C}$, respectivamente. $\mathrm{Em} 800^{\circ} \mathrm{C}$ (Figura 5.16 (a)), nota-se o início da recristalização nesta amostra e, de um modo geral, os grãos recristalizados surgem preferencialmente nas bandas de transição que subdividem o grão. Em $900^{\circ} \mathrm{C}$ (Figura 5.16 (b)), o início da recristalização também ocorreu nas bandas de transição. Na região central das bandas, onde ocorreu a nucleação de um maior número de novos grãos, estes apresentam formato equiaxial, pois os grãos se tocaram no início da recristalização. Os grãos que nuclearam nas extremidades das bandas de deformação cresceram na direção oposta. Eles são alongados preferencialmente na direção da laminação cruzada em sua maioria, porém, alguns também cresceram no sentido da laminação inicial. Esses grãos alongados apresentam a formação de protrusões. Em $1000^{\circ} \mathrm{C}$ (Figura 5.16 (c)), a recristalização é quase completa e segue o mesmo padrão que nas temperaturas mais baixas, tanto quanto ao local de início de recristalização como ao formato dos grãos. 
Figura 5.16 - Visão geral da amostra E-LC recozida por 60 min em: (a) $800^{\circ} \mathrm{C}$; (b) $900^{\circ} \mathrm{C}$; (c) $1000^{\circ} \mathrm{C}$. $\mathrm{DL}$ final é paralela à barra de escala $(\mathrm{MO})$.

(a)
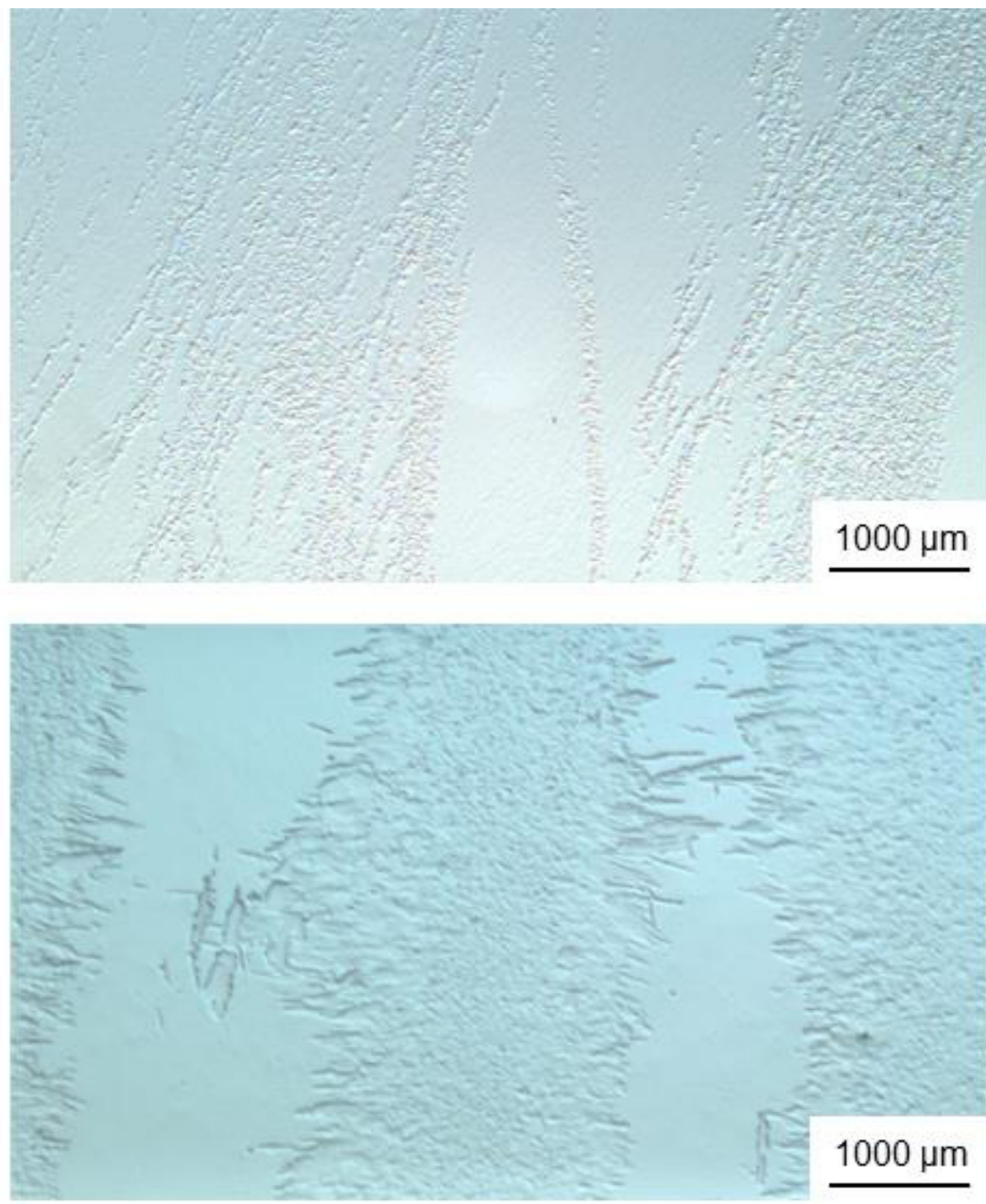

(b)

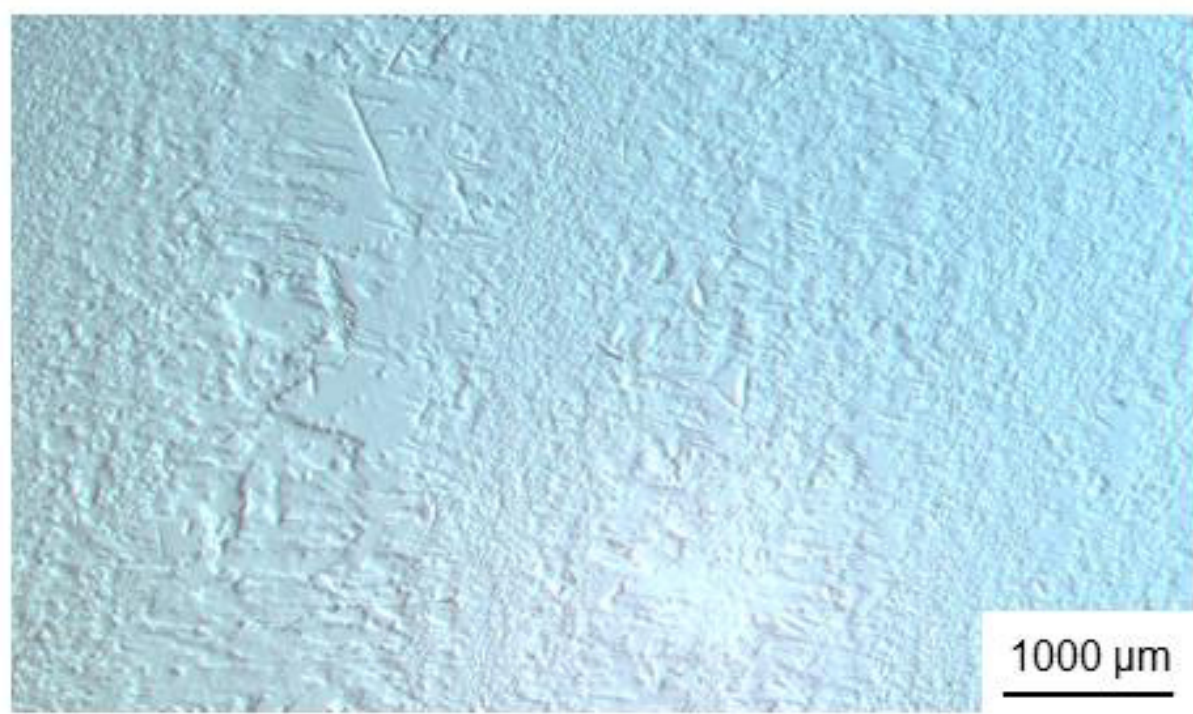

Fonte: a autora. 


\subsubsection{Recozimento em $800^{\circ} \mathrm{C}$}

Em $800^{\circ} \mathrm{C}$ apenas as amostras A-LC e o E-LC recristalizaram parcialmente, razão pela qual foram escolhidas para subsequente caracterização mais detalhada; as demais amostras apenas sofreram recuperação.

Imagens de microscopia eletrônica de varredura de alta resolução da amostra A-LC-800 são mostradas na Figura 5.17. Essa condição foi escolhida para os grãos A e E, pois, permite evidenciar detalhes do início da recristalização; em especial a existência ou não de heterogeneidades de deformação à frente das protrusões, pelo menos em caráter qualitativo.

Esta amostra do grão A provavelmente foi retirada da banda que não apresenta a orientação cubo girado, caso contrário o início da recristalização não iria ocorrer nesta temperatura. Os grãos formados apresentam formatos bem irregulares, possuindo protrusões nos dois sentidos, menos pronunciadas que no grão E como será mostrado mais adiante, tanto no de laminação direta quanto no de laminação cruzada. Sendo assim, a formação de protrusões ocorre já no início da recristalização. Algumas protrusões e retrusões são ondulações menores como as indicadas na Figura 5.17 (b) em vermelho, porém, outras são ondulações maiores, com maior razão de aspecto, como as indicadas nas Figura 5.17 (b) e (c) em azul, tornando o grão mais facetado. As protrusões indicadas em azul provavelmente tiveram uma maior velocidade de migração do contorno, a qual pode estar relacionada à maior energia acumulada à frente do contorno. A organização periódica e regularmente espaçada de um contorno inclinado pode ser visualizada na Figura 5.17 (d), o qual é indicado pela flecha vermelha. 
Figura 5.17 - Micrografia da amostra A-LC-800 (MEV-FEG) sob diversas ampliações.
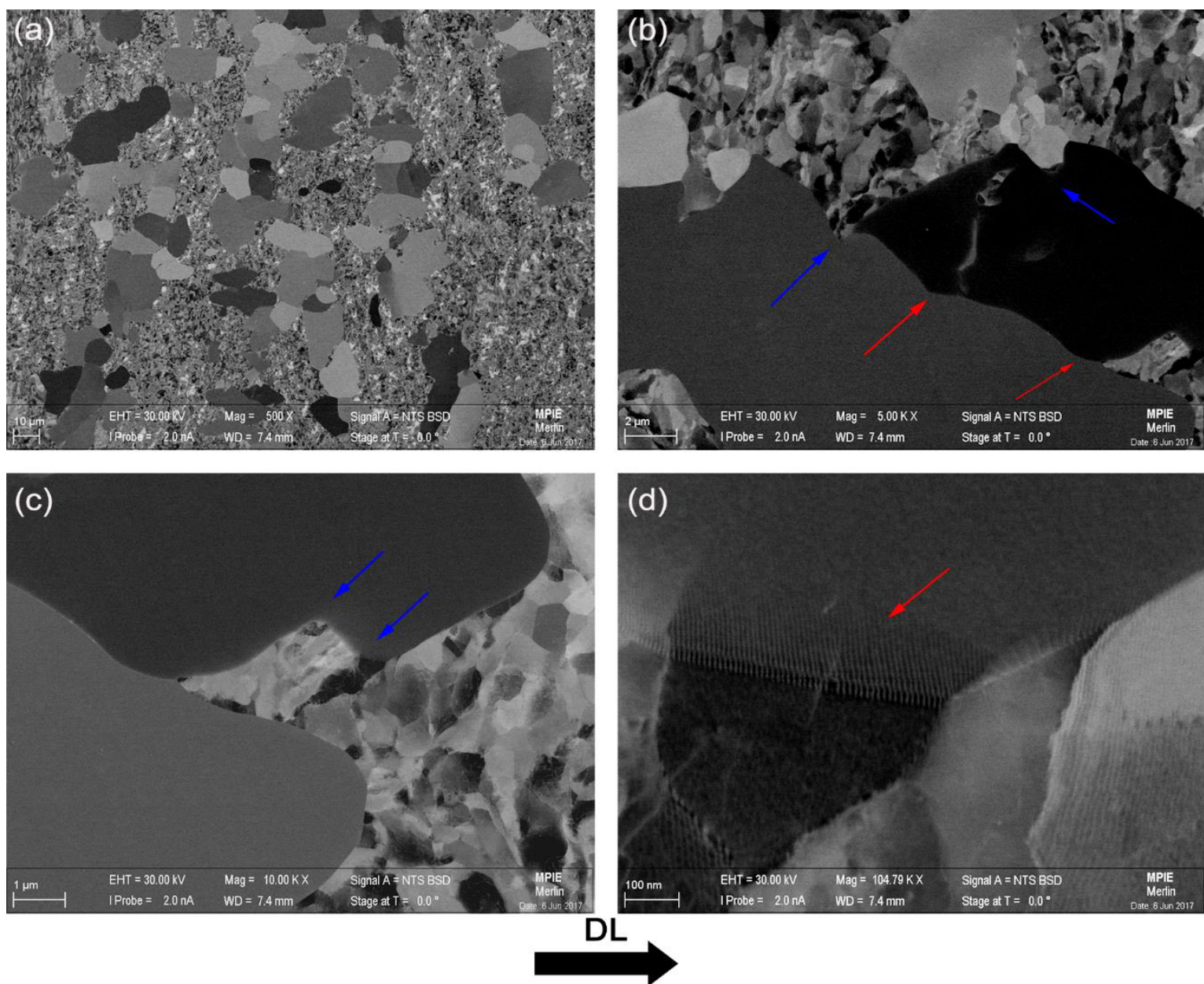

Fonte: a autora.

A Figura 5.18 mostra micrografias da amostra E-LC-800, os grãos são mais alongados no sentido da laminação cruzada e apresentam a formação de protrusões, majoritariamente alinhadas com a direção de laminação cruzada. A razão de aspecto dos grãos recristalizados é aproximadamente 3 . O início da recristalização ocorreu de forma preferencial nas bandas de transição que delimitam outras duas bandas de deformação. Detalhes de uma protrusão encontrada nesta mesma amostra podem serem visualizados em uma imagem obtida em microscopia eletrônica de varredura de alta resolução (Figura 5.19). Na Figura 5.19 (a) a protrusão é a região mais clara que se estende da lateral direita até o centro da imagem e ao seu redor são observados subgrãos, que são estruturas com um maior grau de aperfeiçoamento que as células de discordâncias, já que se formaram numa temperatura mais elevada. Nota-se um certo grau de facetamento do contorno ao longo de sua extensão e que varia de segmento para segmento e de célula/subgrãos imediatamente adjacentes, o que poderia indicar 
uma pequena variação positiva local na velocidade de migração. Uma inspeção mais acurada indicada pelas setas apresentadas nesta figura mostra a presença de leves perturbações na curvatura do contorno migrante com os contornos de subgrãos. Este facetamento pode ser muito mais nítido, tal como o observado em outra protrusão encontrada na mesma amostra, tal como mostra a Figura 5.19 (b). Esta figura apresenta dois grãos recristalizados, sendo um deles equiaxial. Devese ressaltar que essa equiaxialidade pode ter uma explicação meramente estereológica, isto é, uma protrusão crescendo perpendicularmente ao plano de laminação.

Figura 5.18 - Microscopia ótica (MO) da amostra E-LC-800 sob diversas ampliações.
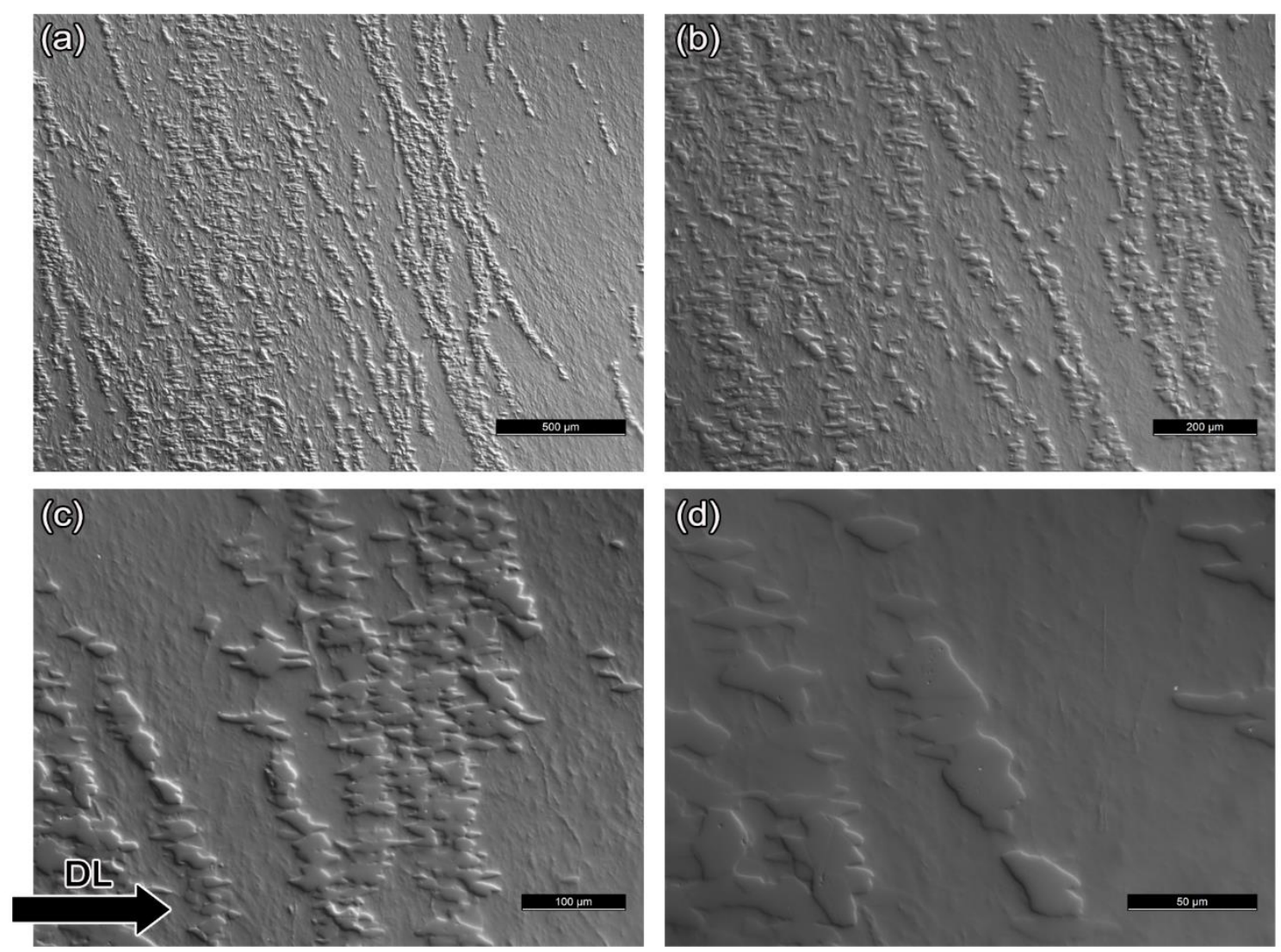

Fonte: a autora. 
Figura 5.19 - Detalhe de uma protrusão na amostra E-LC-800 (ECCI). Note a presença de facetas no contorno associado à protrusão e à subestrutura vizinha, indicadas pelas setas.

(a)

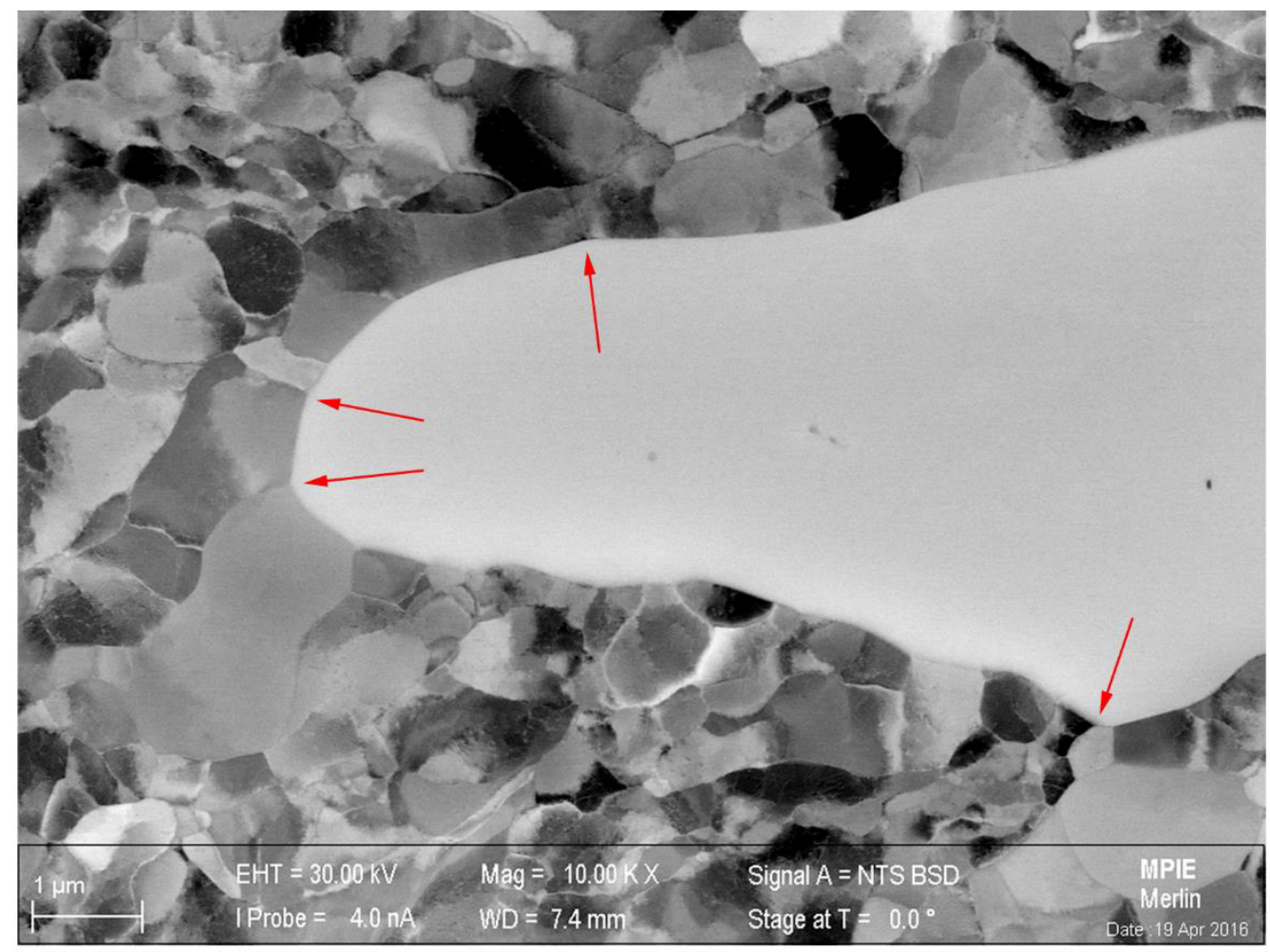

(b)

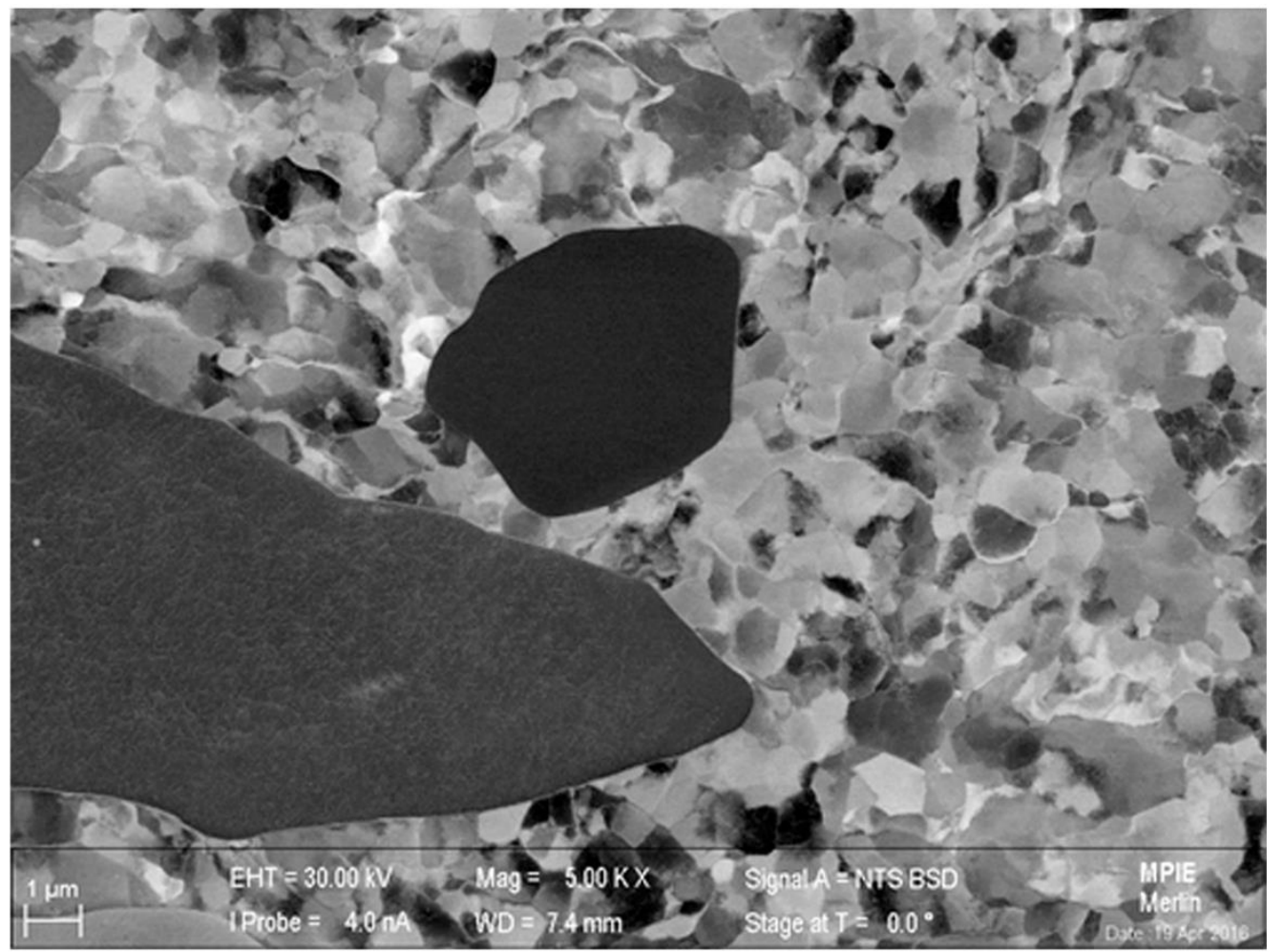

$\mathrm{DL}$

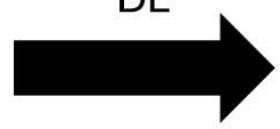

Fonte: a autora. 
A Figura 5.20 (a) apresenta um mapeamento das orientações desta mesma amostra, onde os grãos recristalizados com protrusões encontram-se orientados próximos à (110). Os grãos recristalizados que não exibem protrusões são mais equiaxiais e, em sua maioria, possuem orientações diferentes daqueles grãos com protrusões. Como no caso da amostra A-LC-800, esses grãos equiaxiais podem ser, na realidade, protrusões que migram de forma perpendicular ao plano da imagem (efeito estereológico). Outro ponto digno de nota é a de que as protrusões crescem, em sua maioria, paralelamente à direção de laminação cruzada. A região recuperada adjacente à protrusão apresenta orientação semelhante à orientação inicial do grão. A Figura 5.20 (b) mostra uma ampliação de algumas protrusões paralelas entre si e a região recuperada adjacente. Os contornos de alto ângulo são marcados em preto, os de baixo ângulo em branco e os contornos especiais tipo CSL em vermelho. Próximo às protrusões existem alguns contornos de baixo ângulo, mas eles se encontram ao redor de todo o grão recristalizado (protrusão) e não apenas na frente de recristalização que migrou com maior velocidade. Apenas alguns segmentos dos contornos dos grãos recristalizados são de contornos do tipo CSL, os quais estão presentes em regiões que têm protrusões e em regiões que não têm. Os principais contornos CSL encontrados, em termos quantitativos, são $\Sigma 3$, $\Sigma 9$ e $\Sigma 11$, porém com baixa frequência (inferior a $1 \%$ cada). Deste modo, em princípio, não é possível comprovar a existência de uma relação inequívoca entre a formação de protrusões e a presença de contornos de baixo ângulo das células e subgrãos e/ou contornos CSL. Quantidades semelhantes de contornos CSL podem ser encontradas em amostras recozidas em outras condições, mas por si só não explicam o desenvolvimento das protrusões. Não é possível, também, observar a presença de microbandas ou bandas de transição com elevadas diferenças de orientação associadas imediatamente à frente das protrusões, o que poderia explicar o desenvolvimento de estruturas tão anisotrópicas em termos de razão de aspecto. Isso se repete em outras protrusões nessa amostra, evidenciando a universalidade dessa afirmação. Uma outra hipótese, que ainda carece de comprovação experimental, mas que já foi prevista em simulações computacionais, seria a de que a estrutura do contorno varia com a temperatura (89). Assim, outros tipos de contornos especiais poderiam existir em temperaturas elevadas ou em maior fração. Há, entretanto, dificuldades experimentais quase instransponíveis para esse tipo de investigação experimental. 
Figura 5.20 - Mapeamento das orientações da amostra E-LC-800: (a) visão geral da amostra; (b) detalhe de alguns grãos. Os contornos de baixo ângulo são marcados em branco, os contornos de alto ângulo em preto e os contornos especiais tipo CSL em vermelho.
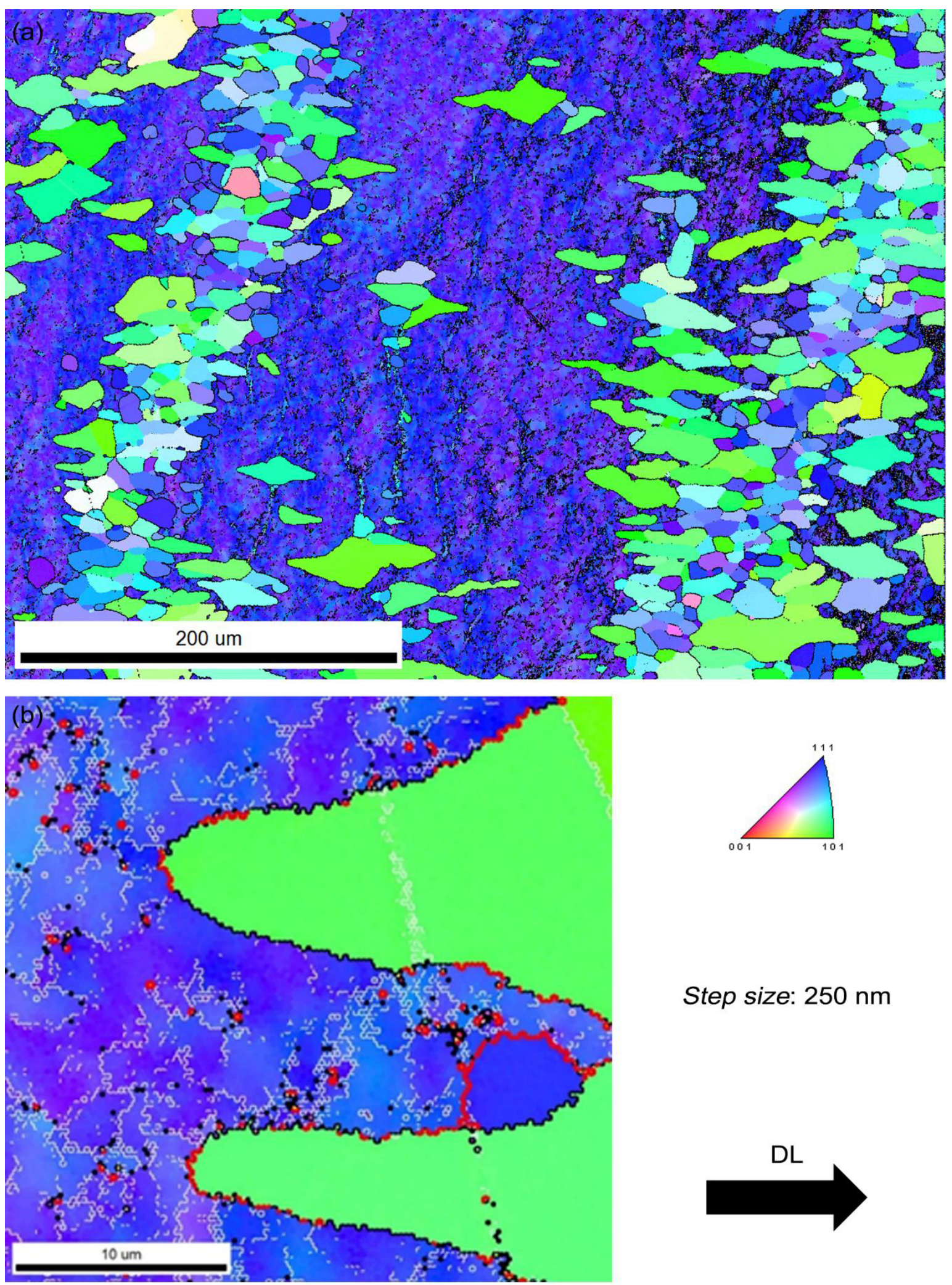

Step size: $250 \mathrm{~nm}$

Fonte: a autora. 
A Figura 5.21 mostra as figuras de polo da amostra E-LC-800, onde a Figura 5.21 (a) é referente a matriz recuperada e a Figura 5.21 (b) é referente aos grãos recristalizados. Os grãos recristalizados apresentam uma forte textura do tipo Goss (15), principalmente os grãos com maior razão de aspecto.

Figura 5.21 - Figura de polo da amostra E-LC-800: (a) matriz recuperada; (b) grãos recristalizados.

(a)

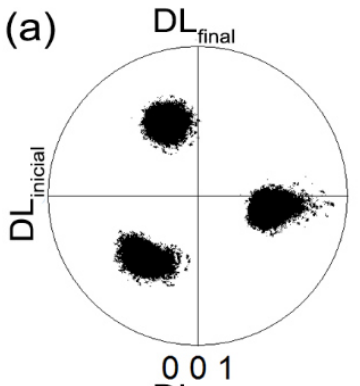

$\mathrm{DL}_{\text {final }}$

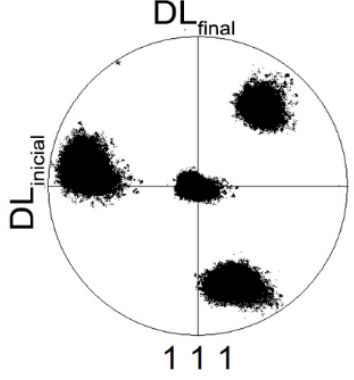

Fonte: a autora.

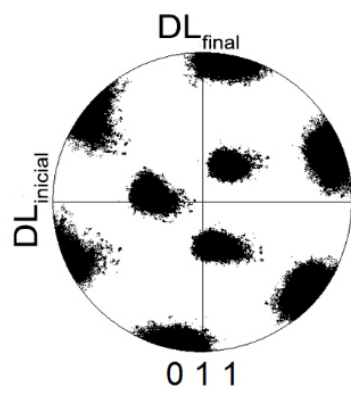

(b)
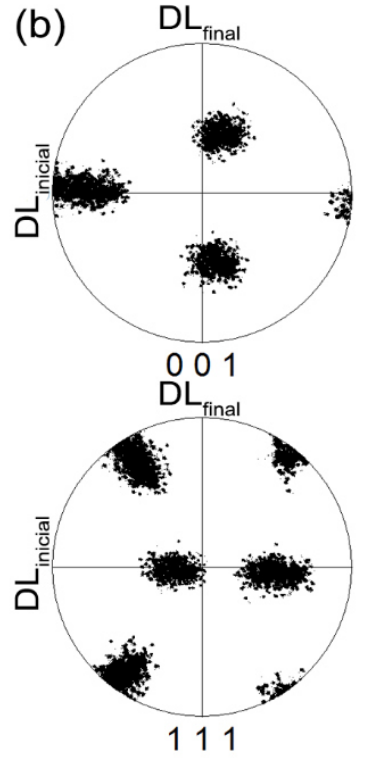

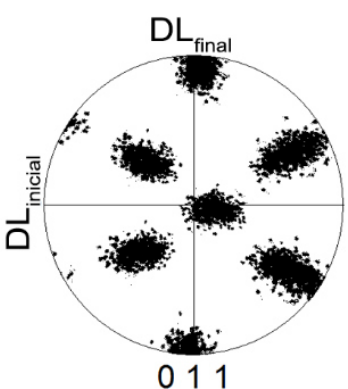

011

\subsubsection{Recozimento em $900^{\circ} \mathrm{C}$}

Em $900^{\circ} \mathrm{C}$, assim como em $800^{\circ} \mathrm{C}$, apenas as amostras A-LC e o E-LC recristalizaram parcialmente. Nesse caso, entretanto, a fração recristalizada e o tamanho dos grãos recristalizados são maiores que em $800^{\circ} \mathrm{C}$. Micrografias da amostra A-LC-900 são mostradas na Figura 5.22. Assim como em $800^{\circ} \mathrm{C}$, o formato do grão recristalizado é irregular com presença de protrusões e parte dos novos grãos formados são alinhados com o sentido de laminação inicial, o que não é observado no grão E. Na Figura 5.22 (a), na região esquerda superior, a amostra apresenta uma morfologia lamelar que é característica do estado encruado. 
Figura 5.22 - Microscopia ótica (MO) da amostra A-LC-900 sob diversas ampliações.
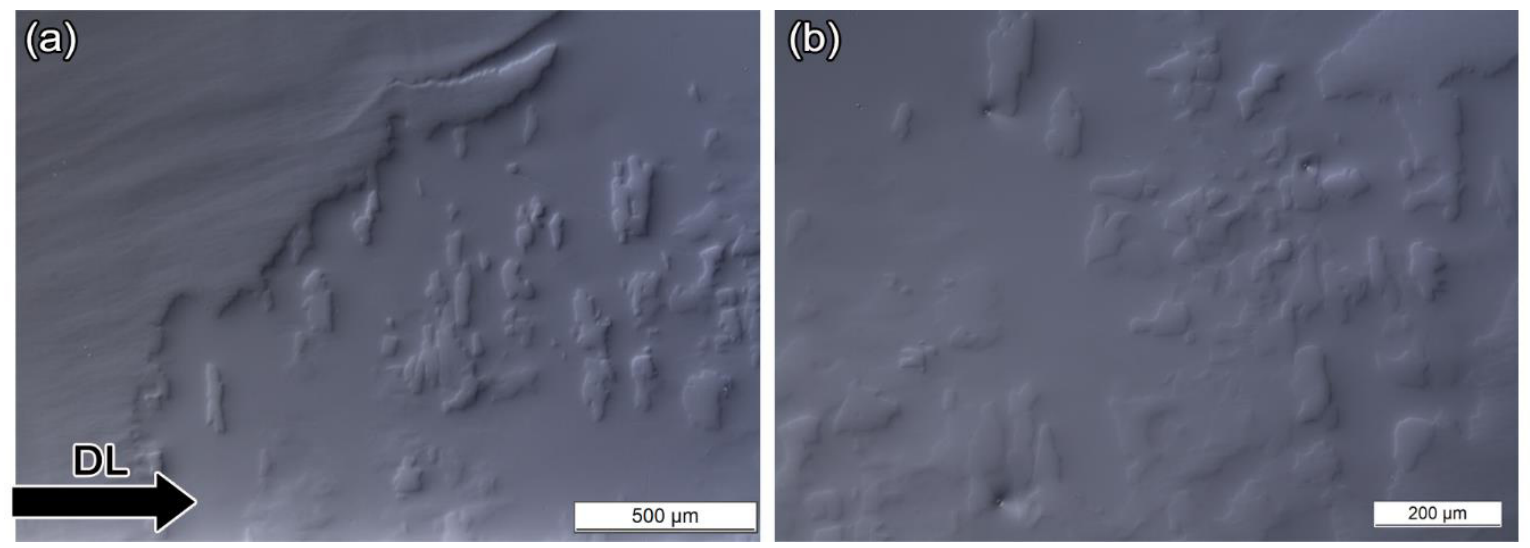

Fonte: a autora.

A Figura 5.23 mostra micrografias da amostra E-LC-900. O início da recristalização desta amostra ocorreu de forma preferencial nas bandas de transição, assim como na amostra E-LC-800. Na região central das bandas, longe das bandas de transição, ocorreu a nucleação de um maior número de novos grãos, a maioria deles com formato equiaxial. Aparentemente, havia muito mais núcleos no interior das bandas que rapidamente se tocaram durante a recristalização em função da temperatura mais elevada, inibindo o crescimento anisotrópico. Os grãos que nuclearam nas extremidades das bandas de transição tiveram uma vantagem cinética inicial e cresceram em direção ao interior das bandas onde a nucleação era mais lenta em razão da inexistência de gradientes de orientação elevados. Eles são alongados na direção da laminação cruzada em sua maioria, porém, uns poucos cresceram no sentido da laminação inicial. Pode-se observar nas micrografias o contorno de grão serrilhado dos grãos alongados. As protrusões formadas apresentam tamanhos e formatos variados. A região destacada da Figura 5.23 (d) é onde foi realizado o mapeamento de orientações.

A Figura 5.24 mostra um mapeamento das orientações desta mesma amostra. A frente de recristalização vai varrendo a amostra, porém, entre os novos grãos formados, algumas regiões ainda permanecem não recristalizadas. A relação de aspecto dos grãos aumenta e fica na faixa 6 a 8 . Esse aumento sugere que a mobilidade na ponta da protrusão é maior do que nos contornos laterais. A razão para tal comportamento ainda não está clara. Como também observado na amostra E-LC-800 (Figura 5.20 (a)), os grãos que apresentam a formação de protrusões são mais alongados e possuem orientação cristalográfica bastante próxima entre si. Neles é possível evidenciar, também, a presença de protrusões secundárias, 
menores que as primárias, que se encontram alinhadas com a direção de laminação antes da rotação de $90^{\circ}$. Esse resultado experimental é bastante relevante. Os grãos sem protrusões têm formato mais próximo ao equiaxial e apresentam orientações diferentes uns dos outros e também em relação às protrusões.

Figura 5.23 - Microscopia ótica (MO) da amostra E-LC-900, diversas ampliações.
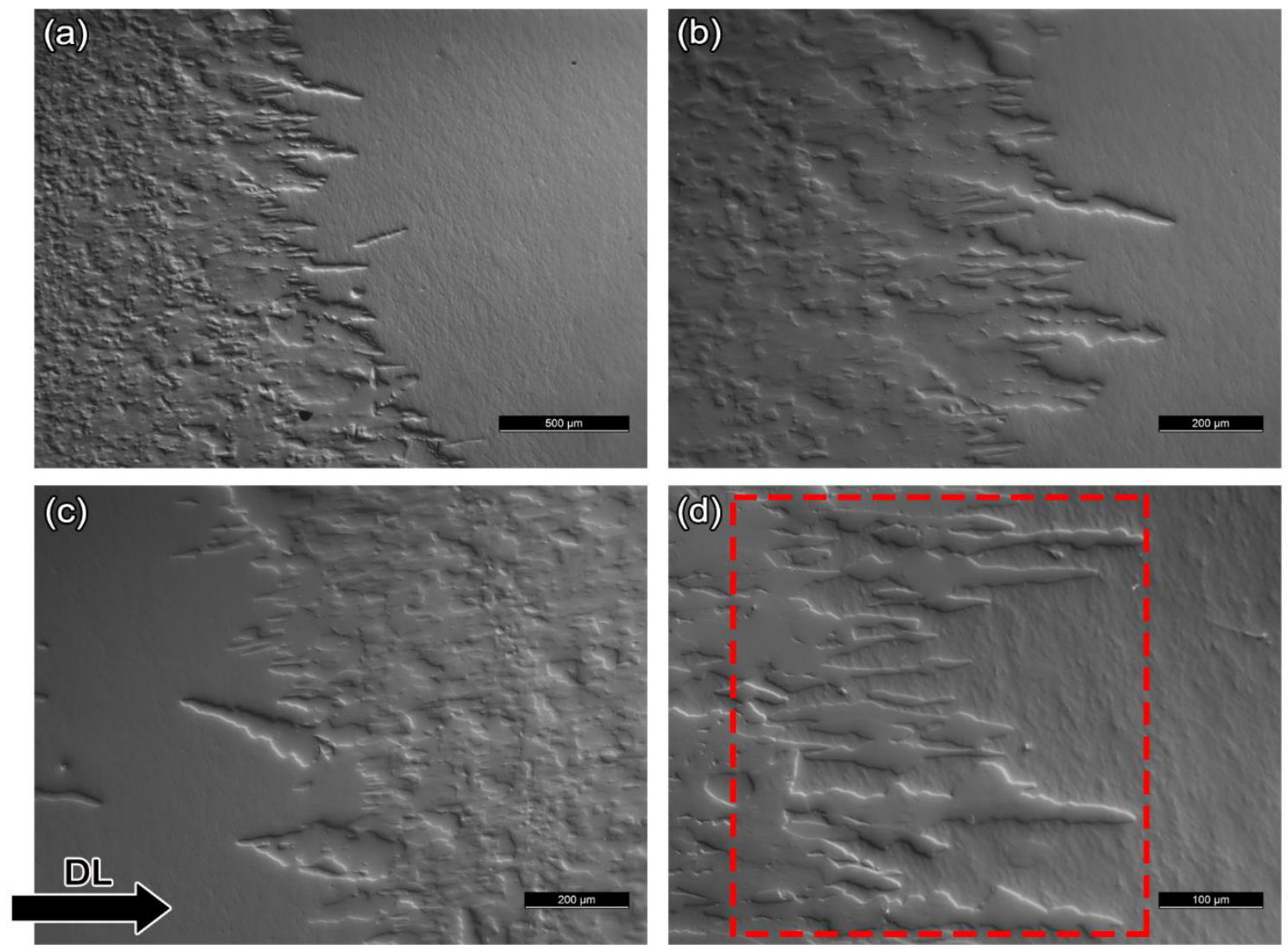

Fonte: a autora. 
Figura 5.24 - Mapeamento das orientações da amostra E-LC-900.

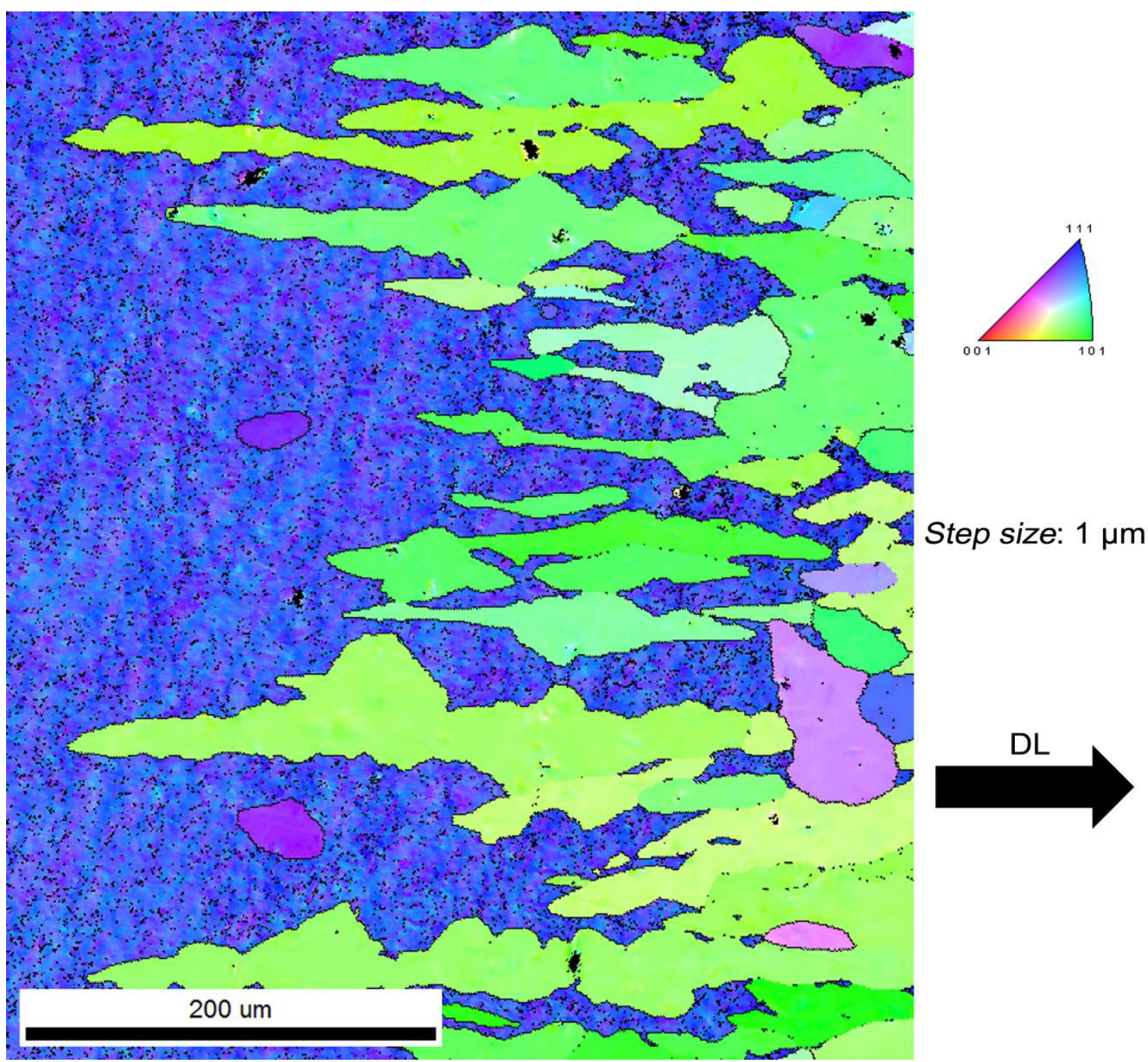

Fonte: a autora.

\subsubsection{Recozimento em $1000^{\circ} \mathrm{C}$}

$\mathrm{Na}$ temperatura de $1000^{\circ} \mathrm{C}$ ocorre recristalização parcial nas amostras ELC-1000 e E-LD-1000. A amostra A-LC, que recristalizou de forma parcial em temperaturas inferiores, não recristalizou nesta temperatura, o que está relacionado à heterogeneidade da deformação (formação de bandas), pois o acúmulo de defeitos varia muito de uma região para outra (ver a variação na dureza Vickers apresentada na Tabela 5.1). Como mostrado anteriormente, o tamanho das bandas é da ordem de alguns milímetros, sendo que algumas amostras foram retiradas de regiões com uma maior quantidade de defeitos e outras de regiões com uma menor 
quantidade de defeitos (erro de amostragem). Isto se reflete de forma substancial na energia acumulada em cada região e, consequentemente, na cinética de recristalização.

A Figura 5.25 mostra micrografias da amostra E-LC-1000. Nesta amostra a recristalização é quase completa. Os mapeamentos de orientação nesta amostra são mostrados nas Figura 5.26, 5.27 e 5.28. Os tamanhos e formas dos grãos recristalizados nesta amostra variam muito. No quesito morfologia, eles se dividem basicamente em grãos equiaxiais, alongados e de formato irregular. No caso do formato irregular, ela pode ser descrita, até por falta de similaridade na literatura, como sendo uma região que se assemelha a uma estrutura esponjosa, ainda não reportada, até onde se saiba. Ao invés de o contorno varrer a microestrutura uniformemente, esta morfologia sugere que a frente de recristalização migra em locais preferenciais de maior energia armazenada, completando o processo de modo mais tardio ao englobar outras regiões com menor energia armazenada. Outra explicação seria a existência de uma frente de recristalização com caráter e mobilidade distintas ao longo do contorno.

Na região de grãos equiaxiais o tamanho médio varia entre 10 e $30 \mu \mathrm{m}$ em diâmetro, e alguns grãos maiores chegam a $500 \mu \mathrm{m}$ em diâmetro. Como a nucleação ocorre de forma facilitada nas bandas de transição, os grãos formados nesta região são os mais finos. Os grãos que crescem entre as bandas apresentam dois formatos principais, sendo um desses formatos o alongado com protrusões no sentido da laminação cruzada e o outro formato são grãos grandes e irregulares com protrusões (lembram o formato de uma esponja). Grande parte dos grãos equiaxiais está orientada próxima ao plano (111) e os grãos alongados estão orientados próximos ao plano (110).

Os grãos maiores durante o seu crescimento deixam regiões não recristalizadas retidas no interior do grão durante a migração do contorno. Um trabalho de simulação de Moelans e colaboradores (35) explica o porquê disto ocorrer. A velocidade de migração tem uma grande variação ao longo do contorno, onde uma parte do contorno fica estagnada e conforme o restante do contorno avança, ocorre o pinch-off, isto é, as regiões do contorno que estavam migrando com maior velocidade tocam-se, formando esta ilha não recristalizada. Na Figura 5.26 está indicado com flechas vermelhas algumas regiões onde isto ocorreu. $\mathrm{Na}$ 
amostra E-LD-1000 a formação dessas estruturas esponjosas ocorre com uma maior frequência.

A Figura 5.27 mostra mapeamentos de orientação da amostra E-LC-1000 com ampliações maiores. A Figura 5.28 mostra um desses mapeamentos com mais detalhes, onde os contornos de baixo ângulo são indicados em branco, e algumas protrusões são destacadas por flechas. Nestas imagens é possível ver com mais detalhes as protrusões formadas. Analisando as protrusões, na maior parte dos casos, elas são formadas em regiões onde existe o encontro de dois subgrãos, isto é, seguindo o subcontorno existente. A migração nesta região ocorre de forma mais acelerada devido a maior energia acumulada. Muitos trabalhos correlacionam a formação das protrusões e consequentes retrusões com a variação da distribuição de energia armazenada no material deformado $(51,55,56)$. A heterogeneidade do material deformado se reflete nos grãos recristalizados, os quais variam em tamanho e forma. Após a nucleação, os grãos vão crescer irregularmente conforme a distribuição de defeitos na sua vizinhança até encontrarem outro grão recristalizado.

Figura 5.25 - Microscopia ótica (MO) da amostra E-LC-1000 sob diversas ampliações.
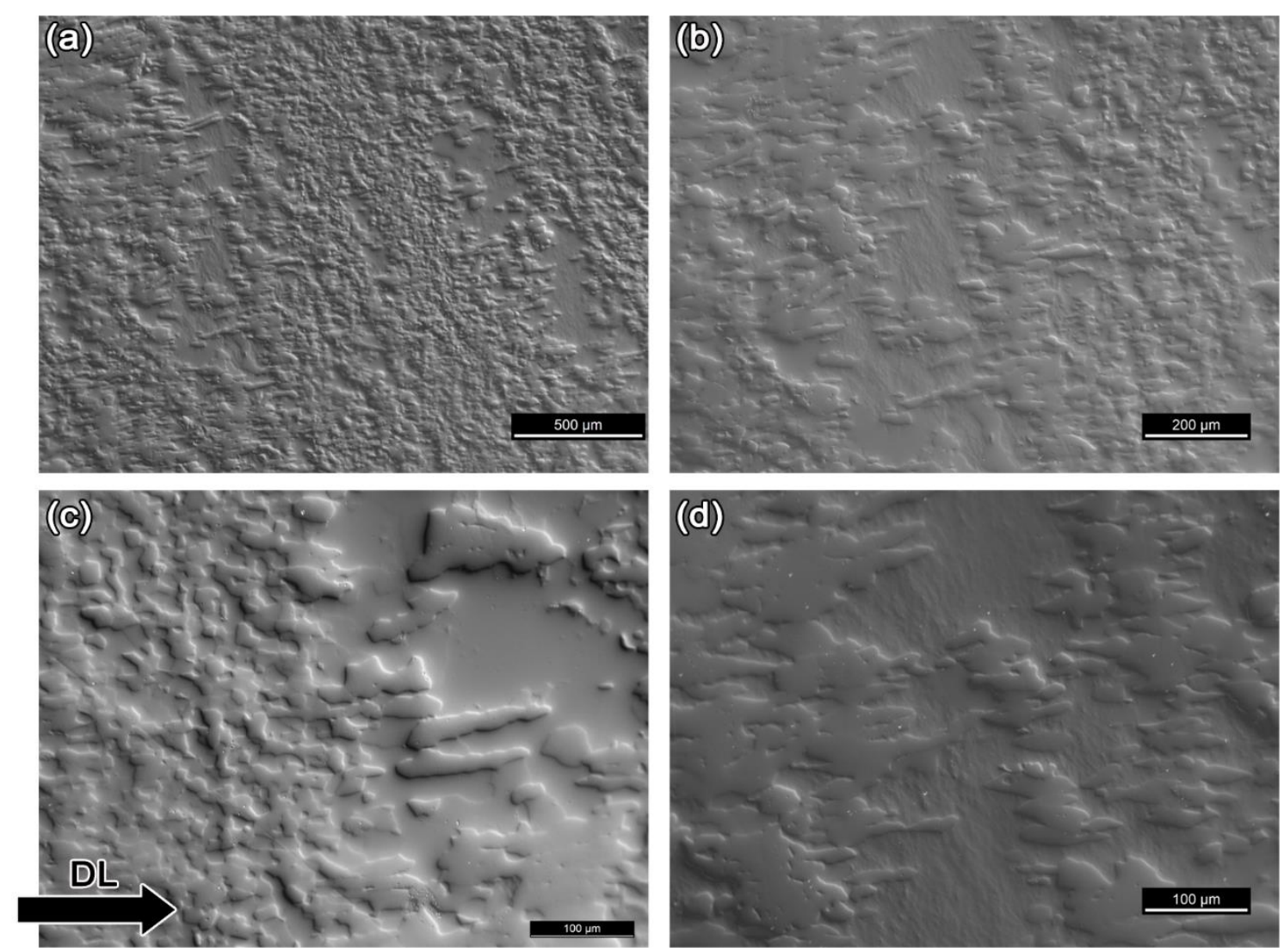

Fonte: a autora. 
Figura 5.26 - Mapeamentos de orientação da amostra E-LC-1000 feitos em diferentes regiões da amostra.
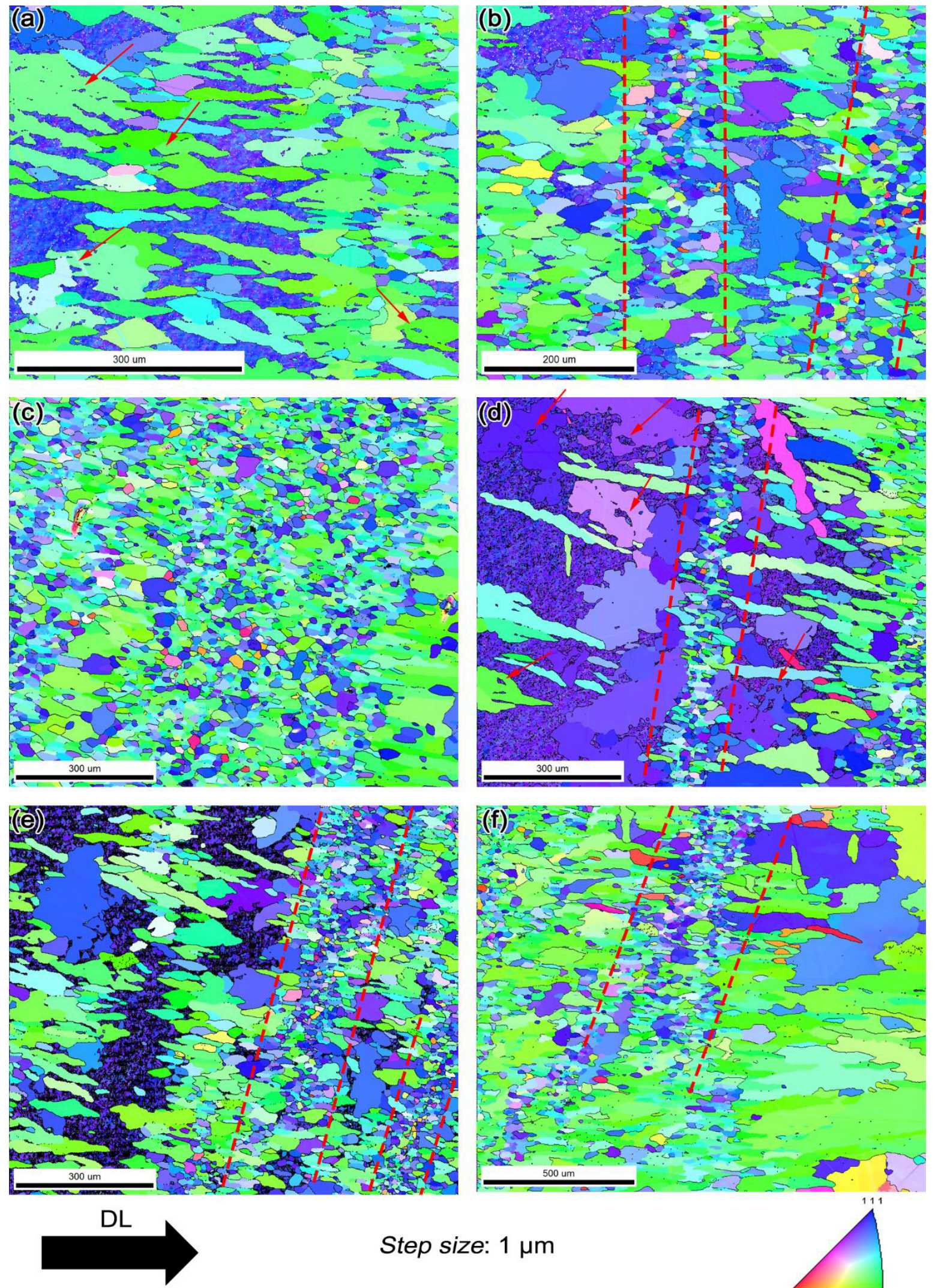

Step size: $1 \mu \mathrm{m}$

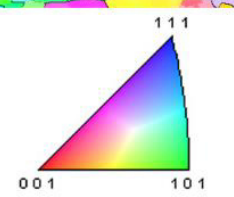

Fonte: a autora. 
Figura 5.27 - Mapeamentos de orientação da amostra E-LC-1000 em diferentes regiões da amostra com maiores ampliações.
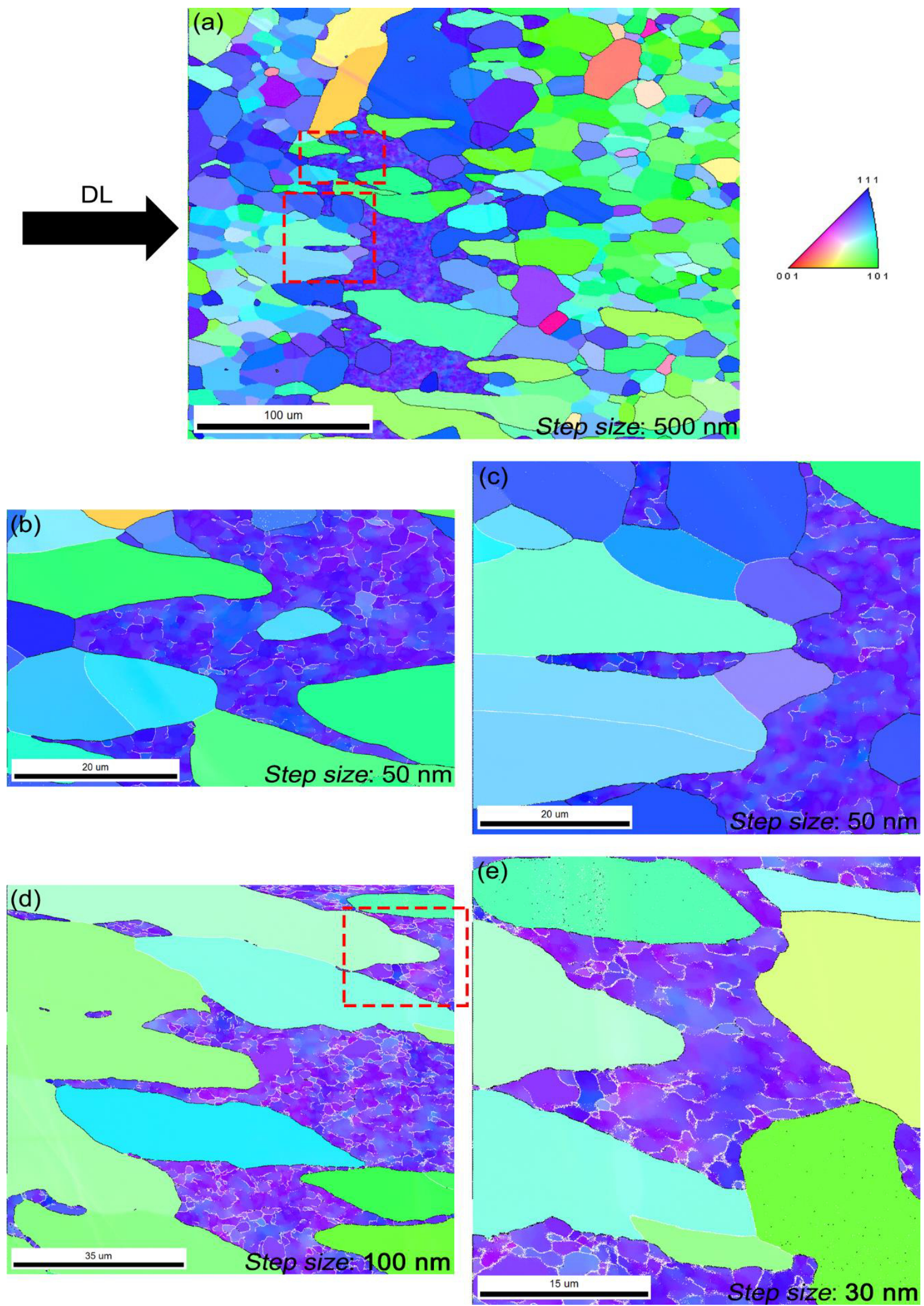

Fonte: a autora. 
Figura 5.28 - Detalhes dos mapeamentos de orientação da amostra E-LC-1000.
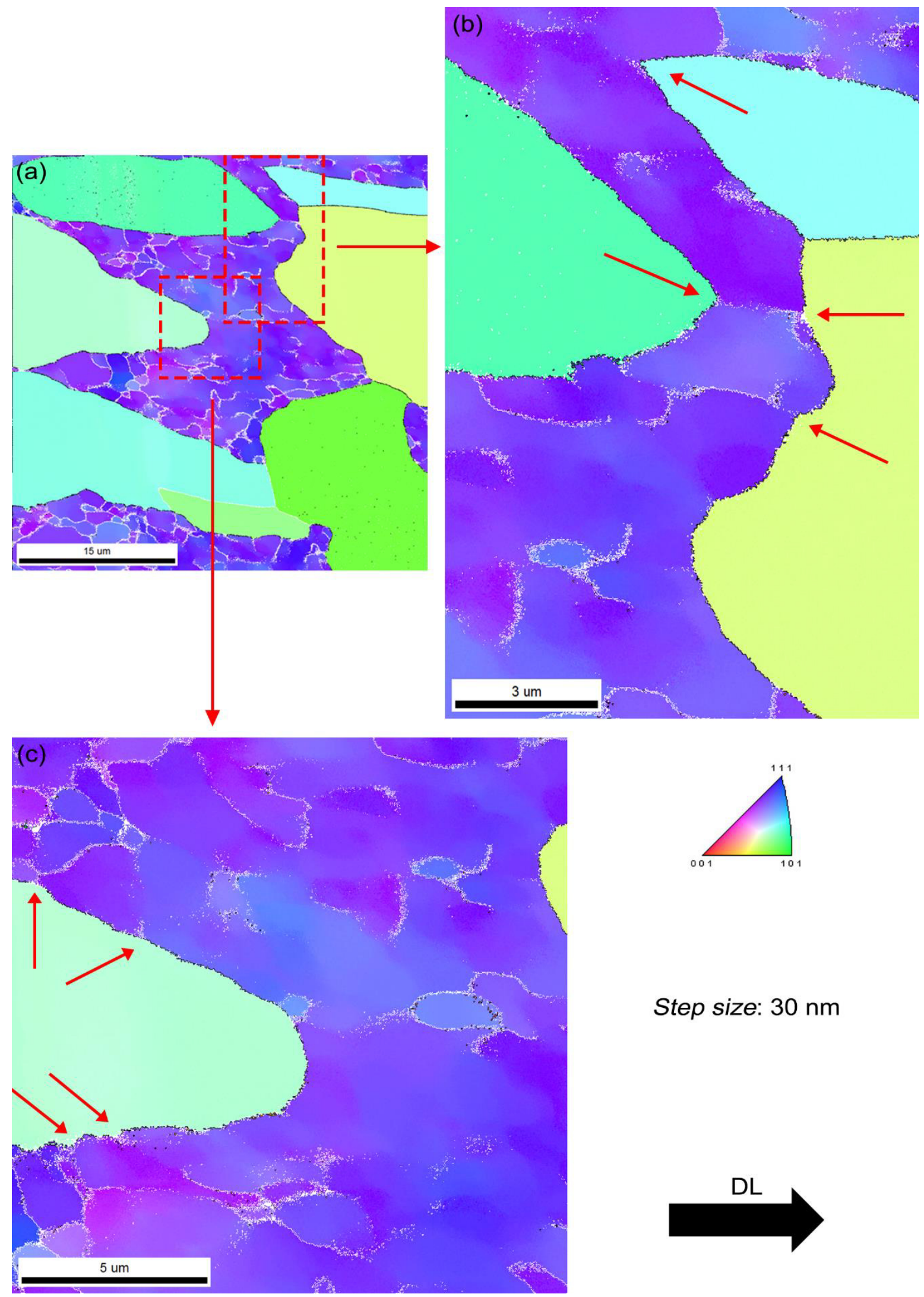

Step size: $30 \mathrm{~nm}$

Fonte: a autora. 
A Figura 5.29 mostra micrografias da amostra E-LD-1000. Os formatos dos grãos recristalizados nesta amostra apresentam estrutura esponjosa, possuem regiões ainda não recristalizadas no seu interior. Essa amostra, particularmente, quase não possui grãos equiaxiais. As regiões não recristalizadas no interior do grão são as mesmas que foram comentadas para a amostra E-LC-1000 que são formadas pelo fenômeno chamado de pinch-off. Esta amostra apresenta um número bem maior dessas estruturas esponjosas.

Figura 5.29 - Microscopia ótica (MO) da amostra E-LD-1000 sob diversas ampliações.
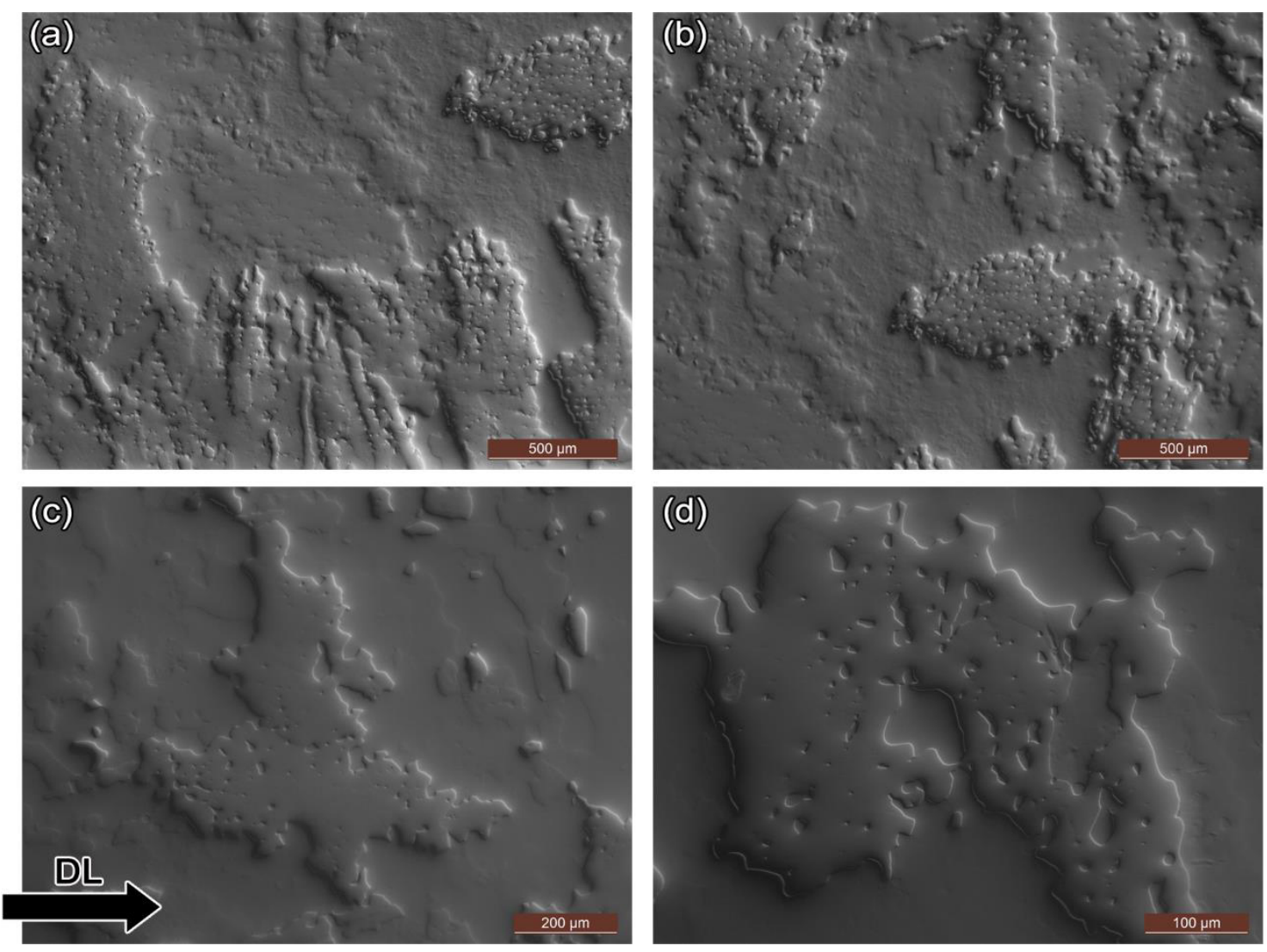

Fonte: a autora.

Segundo a simulação de Moelans e colaboradores (35), isto ocorre quando as regiões com maior acúmulo de energia estão com um maior espaçamento (a simulação utiliza empilhamentos de discordâncias para descrever o acumulo de defeitos). Assim, as partes móveis de um determinado contorno migram muito mais rápido que a parte estagnada, levando à separação de um segmento de contorno, formando a "ilha" não recristalizada. Quanto maior esse espaçamento, mais irregular será o movimento do contorno de grão levado à formação de protrusões e retrusões mais assimétricas. Então, pode-se concluir que a distribuição de defeitos nesta amostra parece encontrar-se mais espaçada comparada com a amostra de 
laminação cruzada. Alguns trabalhos mostram que quando ocorre a mudança de sentido de laminação entre os passes, isso resulta em materiais com a microestrutura deformada mais homogênea se comparada ao material laminado sem mudança de sentido, isto é, de forma direta $(90,91)$. Além disso, a textura apresenta componentes menos intensos devido à ativação de um maior número de sistemas de escorregamento (92).

Nesta amostra não existe um sentido preferencial para o crescimento (expansão) do grão na recristalização. Em algumas regiões, diversos grãos crescem perpendicularmente à direção de laminação. Vale ressaltar que, devido a este fato, foi preparada mais de uma amostra nesta condição para avaliar se houve algum equívoco na preparação da primeira amostra. Os resultados obtidos são iguais aos obtidos inicialmente.

A Figura 5.30 mostra mapeamentos de orientação da amostra E-LD-1000. A Figura 5.31 mostra um desses mapeamentos com mais detalhes. A forma e 0 tamanho dos grãos variam e a maior parte dos grãos formados apresenta ilhas não recristalizadas no interior da estrutura esponjosa. Alguns grãos mudam gradativamente a sua orientação, por exemplo o grão destacado na Figura 5.30 (c).

A Figura 5.31 mostra um mapeamento de EBSD da amostra E-LD-1000 com uma maior ampliação, mostrando assim mais detalhes da microestrutura. Os subgrãos localizados ao redor dos grãos recristalizados cresceram mais que os demais e o contornos dos grãos recristalizados avançaram mais na região dos contornos de baixo ângulo. As flechas na Figura 5.31 (b) indicam alguns exemplos. Também é possível observar que algumas ilhas, formadas dentro dos grãos recristalizados, apresentam contornos de baixo ângulo em seu interior e outras não.

Huh, Engler e Raabe investigaram o efeito da laminação cruzada na textura de aços de baixo carbono (93). Eles relataram que importantes rotações dos arranjos de discordâncias e microbandas promoveram um aumento de bandas de cisalhamento nas chapas de aço. Mudanças na trajetória da laminação promoveram mudanças importantes no comportamento de recristalização do grão E, afetando a fração recristalizada, a forma e tamanho dos grãos e a textura dos grãos recristalizados. 
Figura 5.30 - Mapeamentos de orientação da amostra E-LD-1000 em diferentes regiões da amostra.
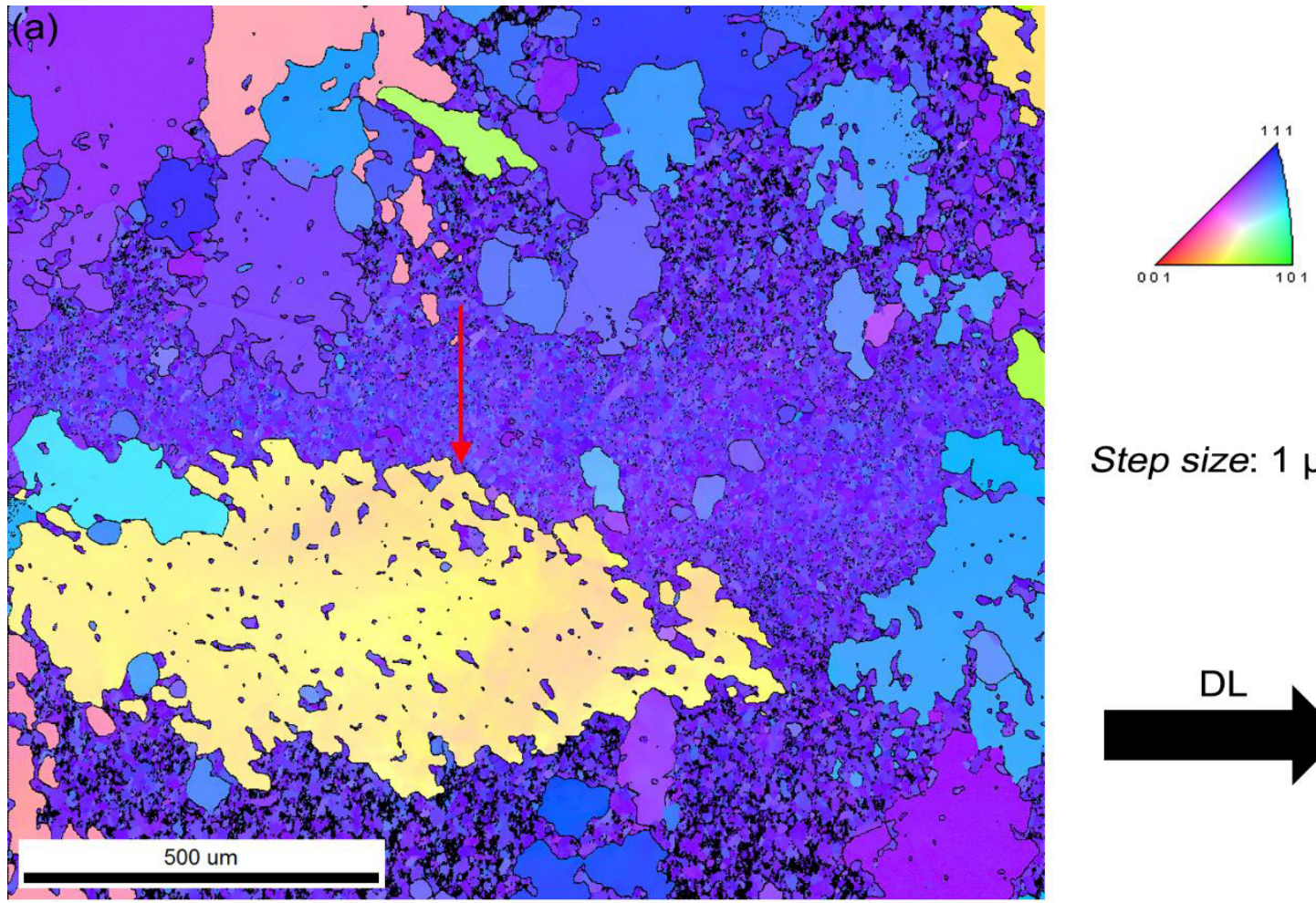

Step size: $1 \mu \mathrm{m}$
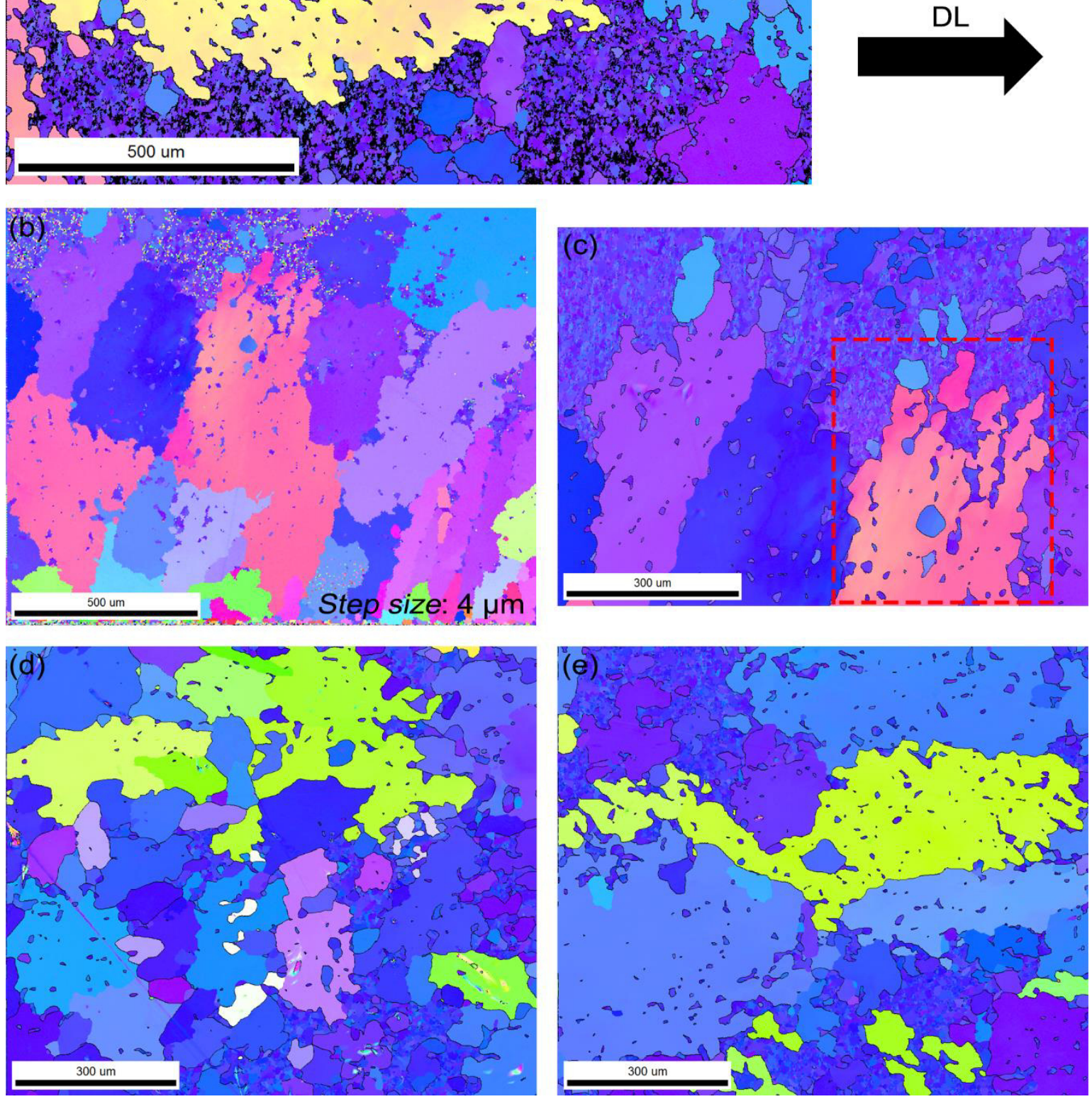

Fonte: a autora. 
Figura 5.31 - Detalhes do mapeamento de orientações via EBSD da amostra E-LD-1000.
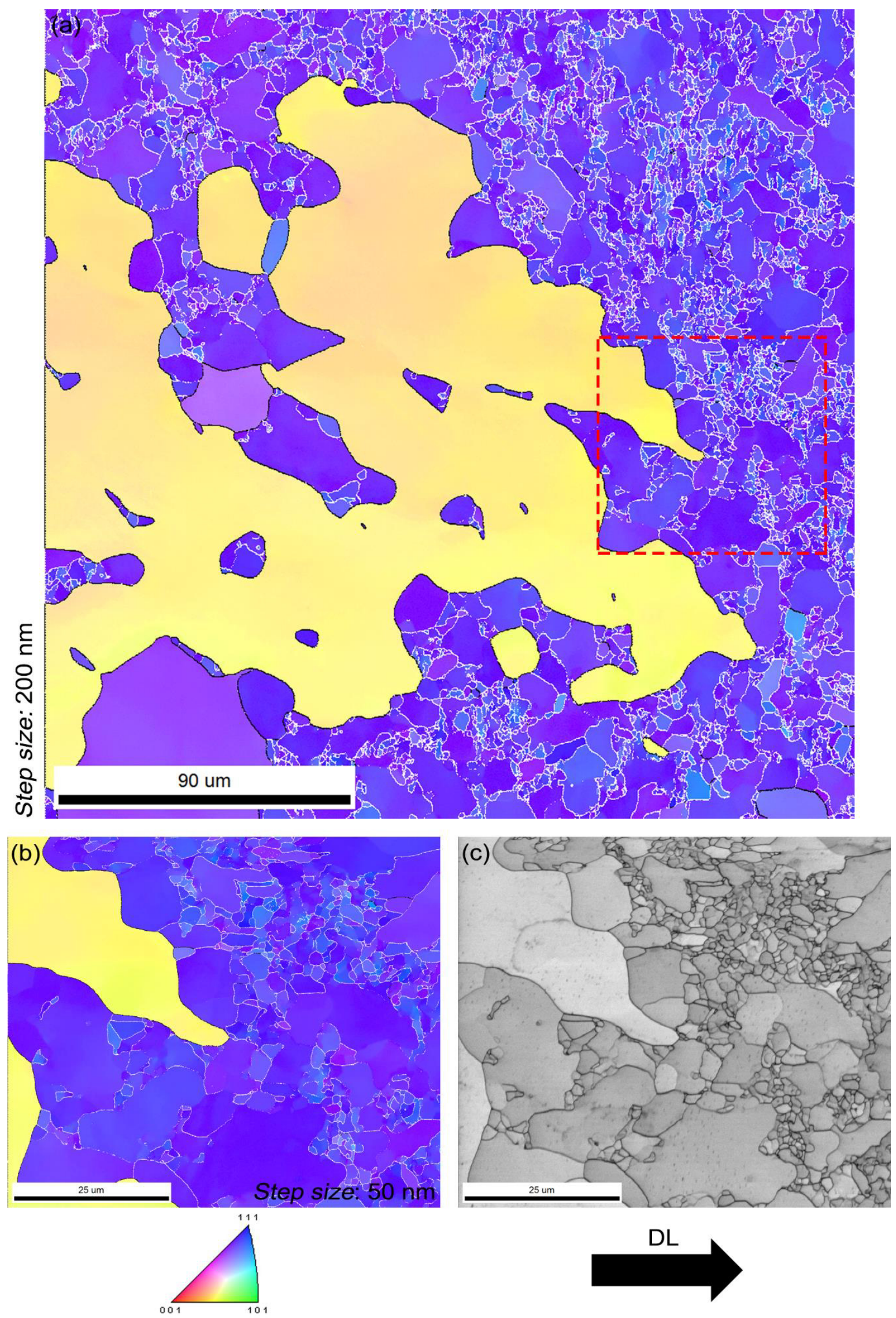

Fonte: a autora. 


\subsubsection{Recozimento em $1100^{\circ} \mathrm{C}$}

Em $1100^{\circ} \mathrm{C}$ ocorre a recristalização das amostras A-LC-1100, E-LC-1100 e E-LD-1100 e as suas micrografias são mostradas nas Figura 5.32, 5.32 e 5.33, respectivamente. Para os dois grãos que foram laminados de forma cruzada, a recristalização ocorreu preferencialmente nas bandas de transição, enquanto que para o grão laminado de forma direta isto não ocorreu. Tanto para a amostra A-LC1100 como a E-LC-1100, a microestrutura é bastante heterogênea, sendo formada por faixas de grão menores equiaxiais alternadas com faixas de grãos maiores alongados no sentido da laminação cruzada. Os grãos apresentam a formação de protrusões. Estas faixas de microestrutura alternadas estão marcadas nas Figura 5.32 (a) e Figura 5.33 (a) e (b). Já para a amostra E-LD-1100, a microestrutura é semelhante àquela formada em $1000^{\circ} \mathrm{C}$, onde os grãos apresentam forma bastante irregular e tamanhos muito variados, porém, apresentam um número bem menor de ilhas não recristalizadas na estrutura esponjosa. Algumas destas ilhas estão destacadas com flechas na Figura 5.34 (d).

Figura 5.32 - Microscopia ótica (MO) da amostra A-LC-1100 sob diversas ampliações.
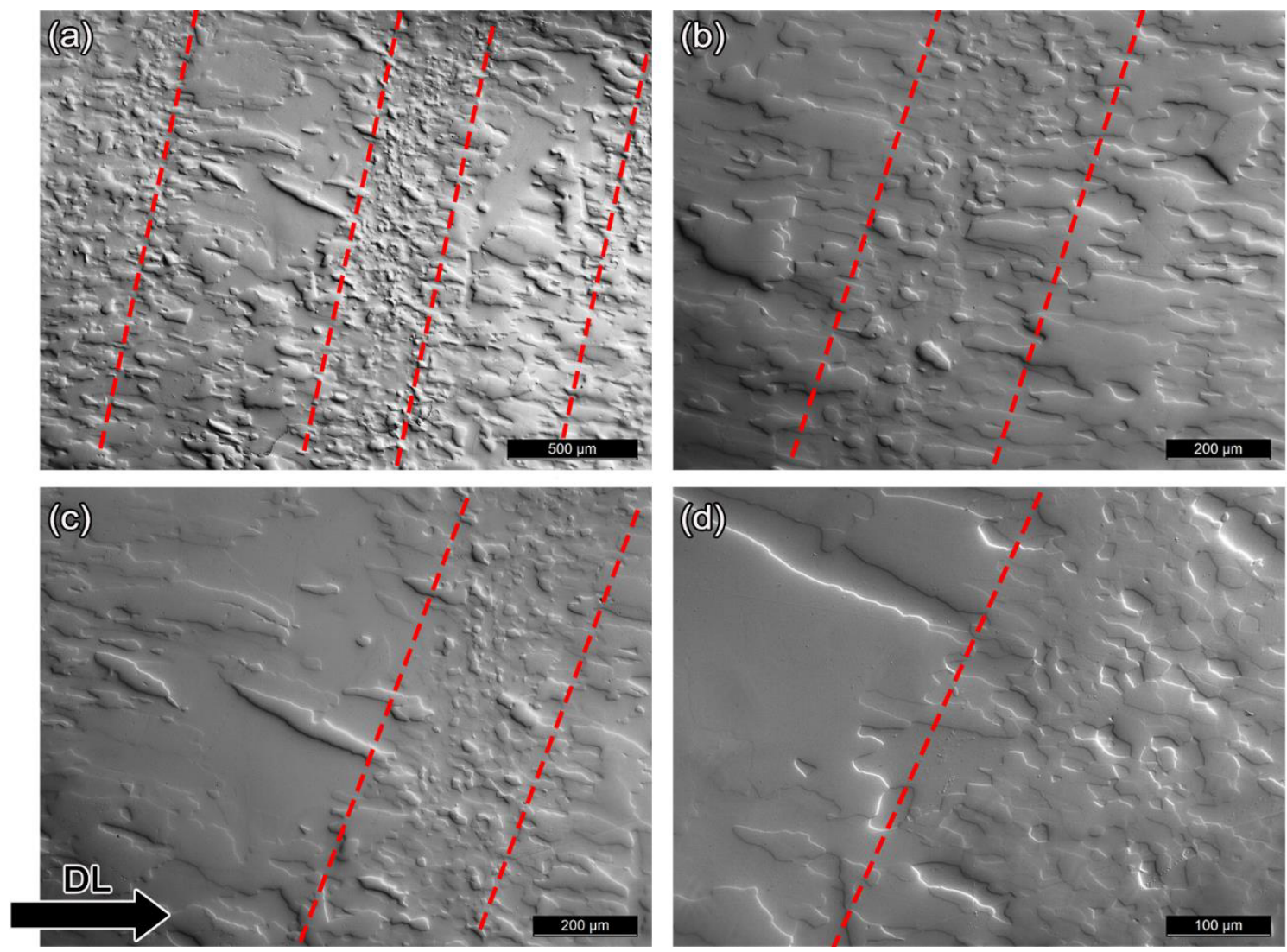

Fonte: a autora. 
Figura 5.33 - Microscopia ótica (MO) da amostra E-LC-1100 sob diversas ampliações.
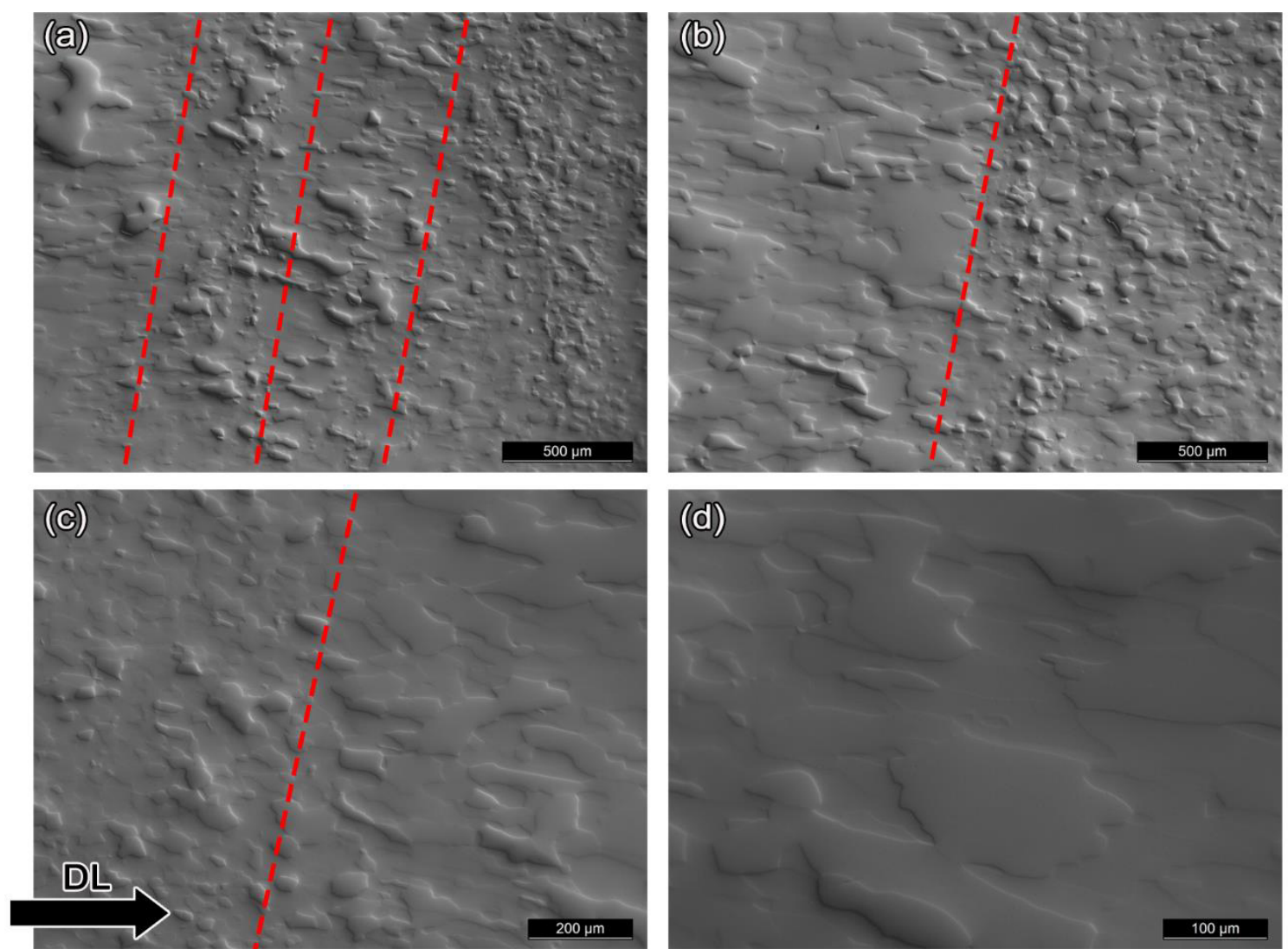

Fonte: a autora.

Figura 5.34 - Microscopia ótica (MO) da amostra E-LD-1100 sob diversas ampliações.
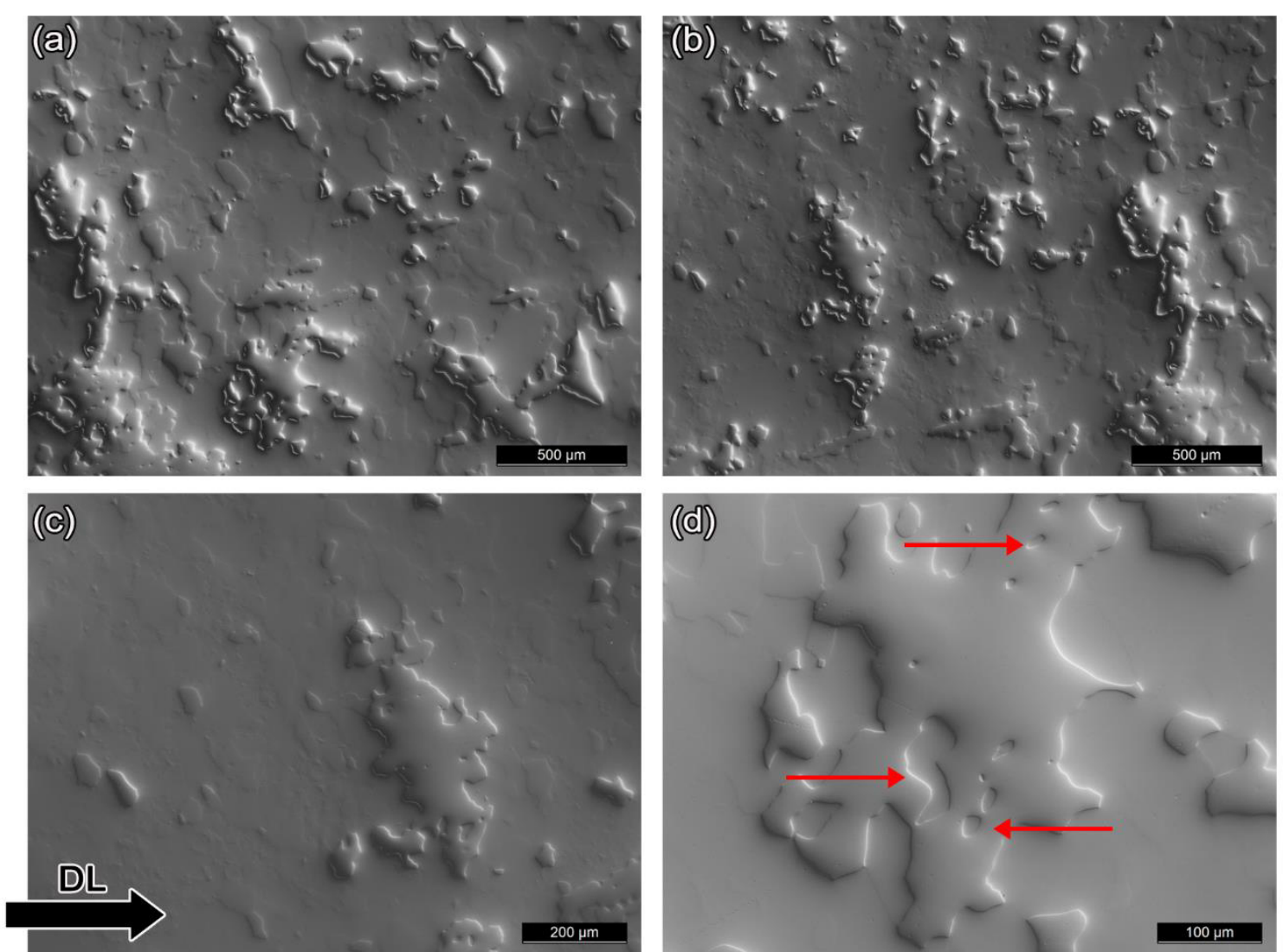

Fonte: a autora. 


\subsubsection{Recozimento em $1200^{\circ} \mathrm{C}$}

Em $1200^{\circ} \mathrm{C}$ ocorreu a recristalização das amostras A-LC, C-LC, E-LC, ALD e E-LD. A amostra A-LC-1200 (Figura 5.35) apresenta uma estrutura heterogênea semelhante a formada em $1100^{\circ} \mathrm{C}$, sendo formada por faixas de grão menores equiaxiais alternadas com faixas de grãos maiores alongados no sentido da laminação cruzada. Os grãos recristalizados da amostra C-LC-1200 (Figura 5.36) são alongados no sentido da laminação cruzada e apresentam a formação de protrusões. O E-LC-1200 (Figura 5.37) possui uma microestrutura recristalizada diferente das encontradas nas temperaturas inferiores, sendo formada predominantemente por grãos equiaxiais.

Figura 5.35 - Microscopia ótica (MO) da amostra A-LC-1200 sob diversas ampliações.
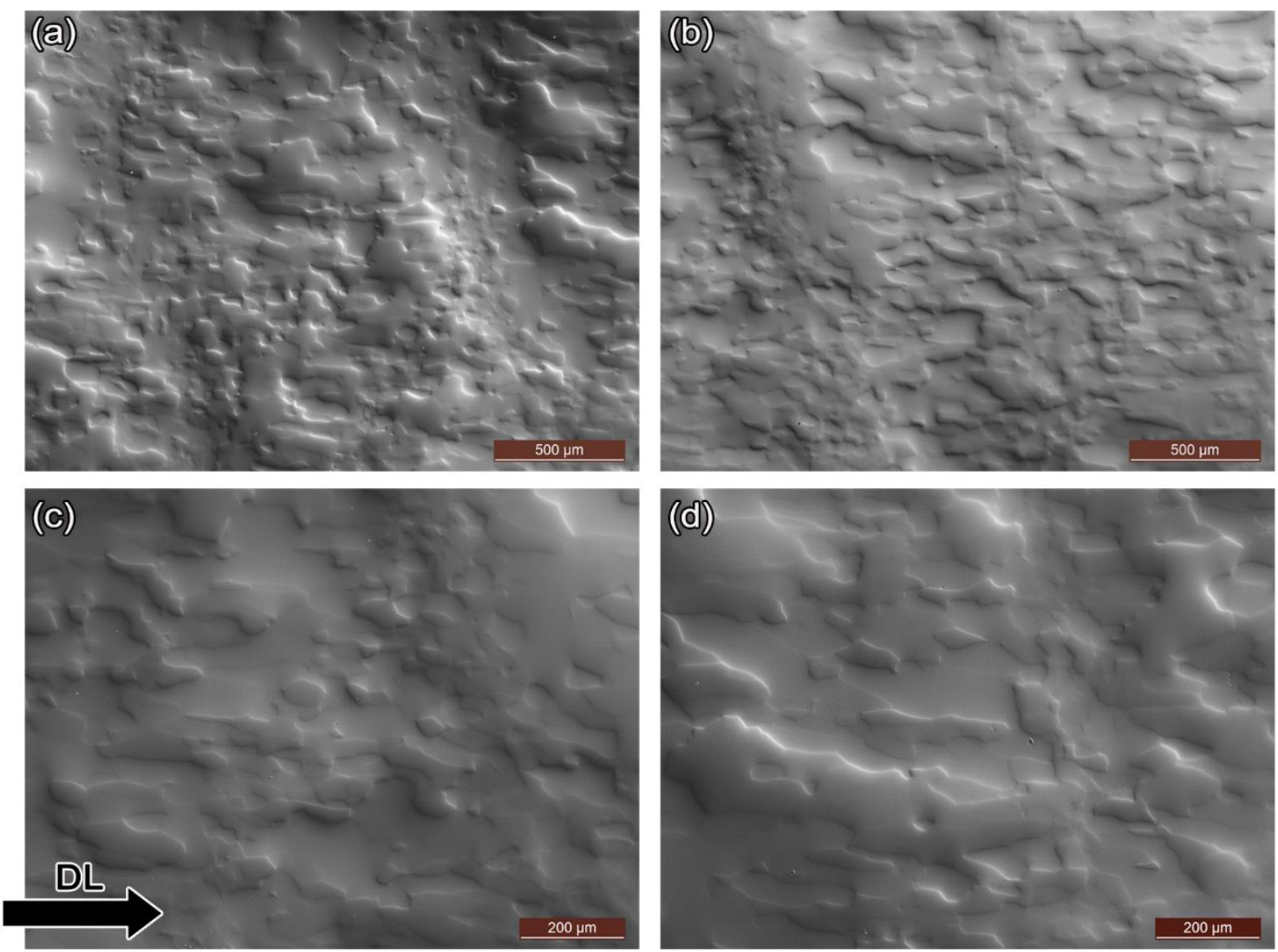

Fonte: a autora. 
Figura 5.36 - Microscopia ótica (MO) da amostra C-LC-1200 sob diversas ampliações.
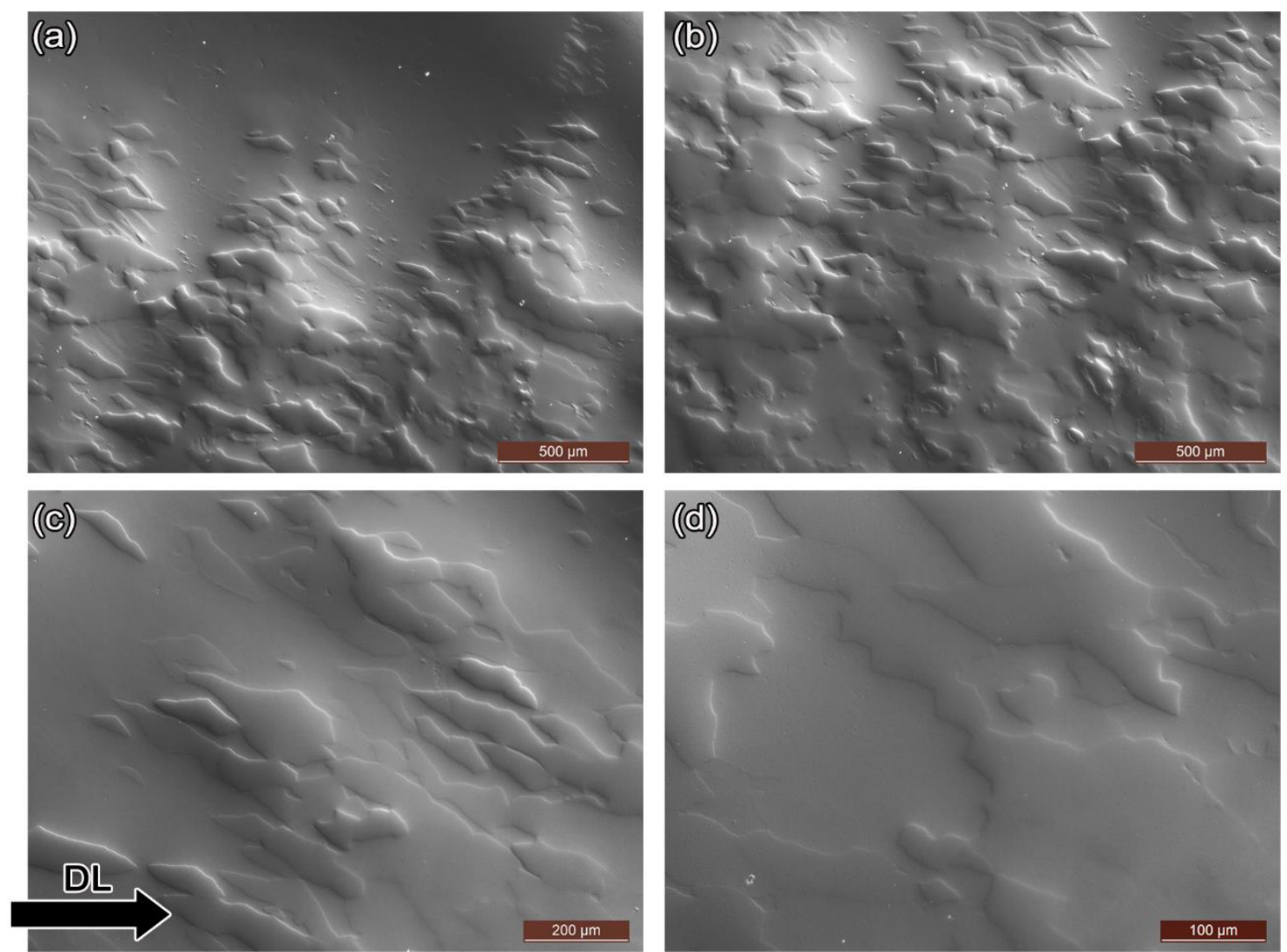

Fonte: a autora.

Figura 5.37 - Microscopia ótica (MO) da amostra E-LC-1200. DL final, após rotação de $90^{\circ}$, é paralela à barra de escala.

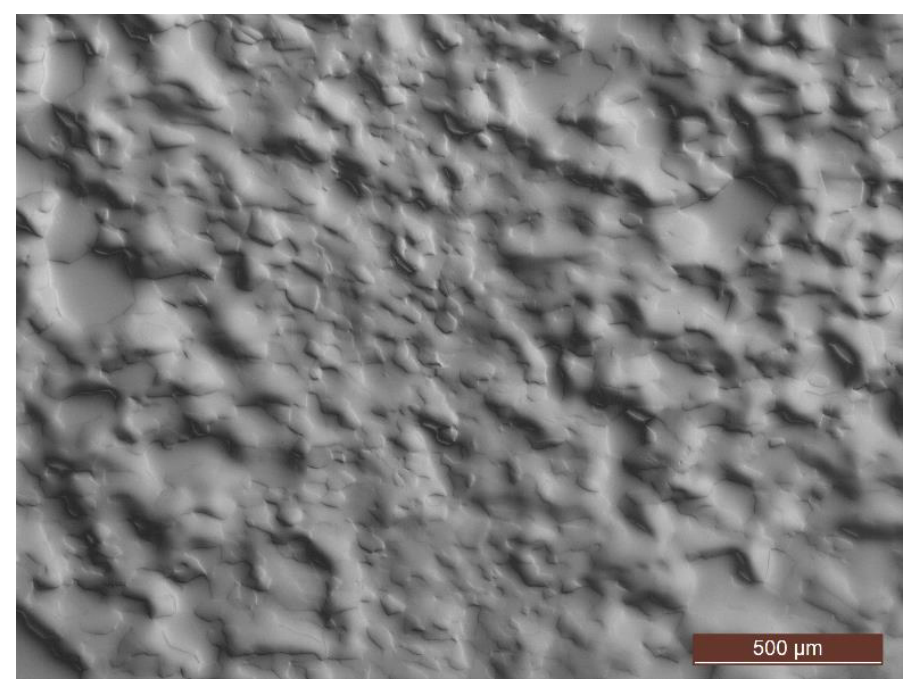

Fonte: a autora.

As Figura 5.38, 5.39 e 5.40 mostram o mapeamento de orientações via EBSD, as figuras de polo e a distribuição de desorientação dos contornos para as amostras A-LC-1200, C-LC-1200 e E-LC-1200, respectivamente. Nos mapeamentos de orientação, os contornos de baixo ângulo estão representados 
em branco e os contornos de alto ângulo em preto. A microestrutura das amostras laminadas de forma cruzada após o recozimento em $1200^{\circ} \mathrm{C}$ é bastante heterogênea em termos de tamanho de grão recristalizado e textura. Esse comportamento é semelhante aos relatados em alumínio de grão grosseiro (84) e tântalo de grão grosseiro (86).

Como pode ser observado nos gráficos as distribuições de desorientações, das três amostras apresentam uma alta fração de contornos de baixo ângulo comparado com os de alto ângulo, sendo 61\% para a A-LC-1200, 93\% para a CLC-1200 e 76\% para a E-LC-1200.

Os números encontrados para a fração dos contornos de baixo ângulo têm diferentes explicações. Para a amostra A-LC-1200 (Figura 5.38 (a)) estão destacadas as diferentes regiões, isto é, a faixa onde a recristalização ocorreu na banda de transição e originou grãos menores equiaxiais e a região entre as bandas onde os grãos estão alongados no sentido da laminação cruzada, isto é, aqueles formados a partir da nucleação nas bandas de transição. Grande parte dos grãos alongados estão orientados próximo ao plano (110) e a orientação dos grãos equiaxiais em sua maioria varia entre o plano (110) e o plano (111). A maioria dos grãos recristalizados é desviado cerca de $15^{\circ}$ do componente Goss ideal, $\{110\}$ $<100>$.

A amostra C-LC-1200 (Figura 5.39 (a)) tem a maior fração de limites de baixo ângulo porque sofreu recuperação prolongada em vez de recristalização primária. A matriz é recuperada e somente alguns grãos com diferentes orientações podem ser notados na microestrutura.

A amostra E-CR-1200 (Figura 5.40 (a)) tem uma microestrutura recristalizada equiaxial quase orientada por Goss e o grande número de contornos de baixo ângulo é explicado por sua forte textura. À primeira vista, essa microestrutura não mostra nenhuma reminiscência das protrusões indicando seu caráter transitório durante a recristalização primária. 
Figura 5.38 - Mapeamento de orientação via EBSD da amostra A-LC-1200: (a) mapeamento de orientações; (b) figuras de polo discretas; (c) distribuição de desorientações.

(a)
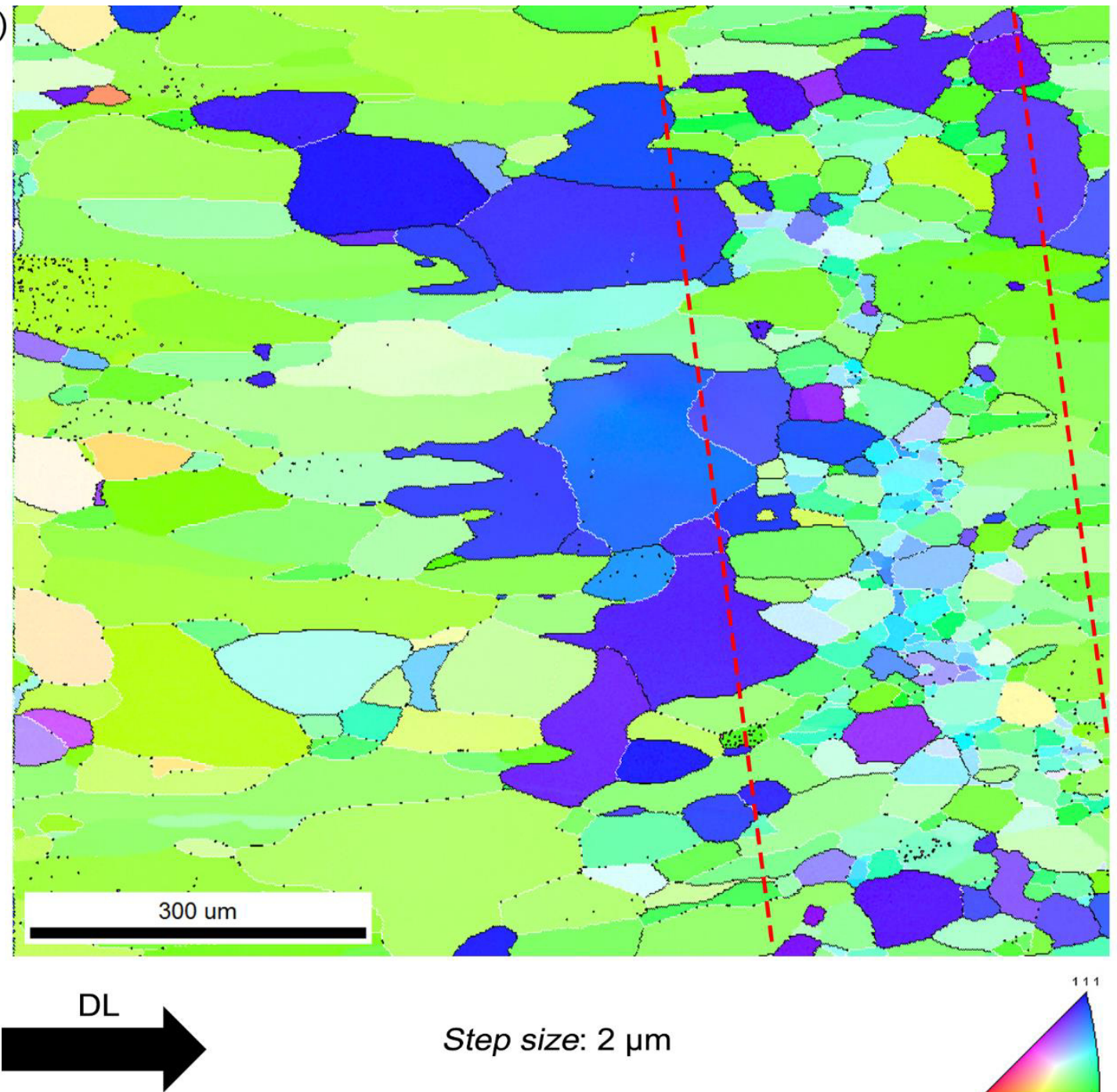

Step size: $2 \mu \mathrm{m}$
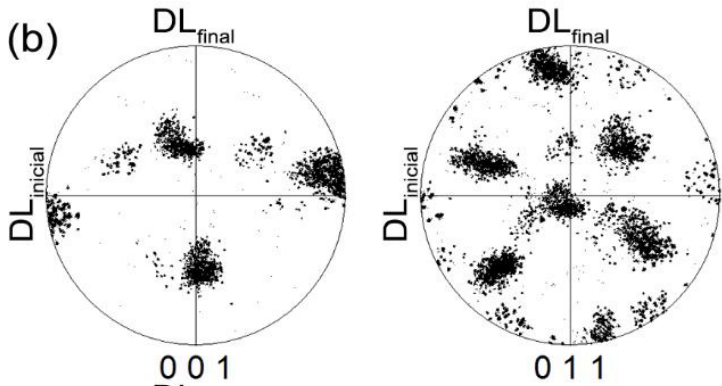

(c)
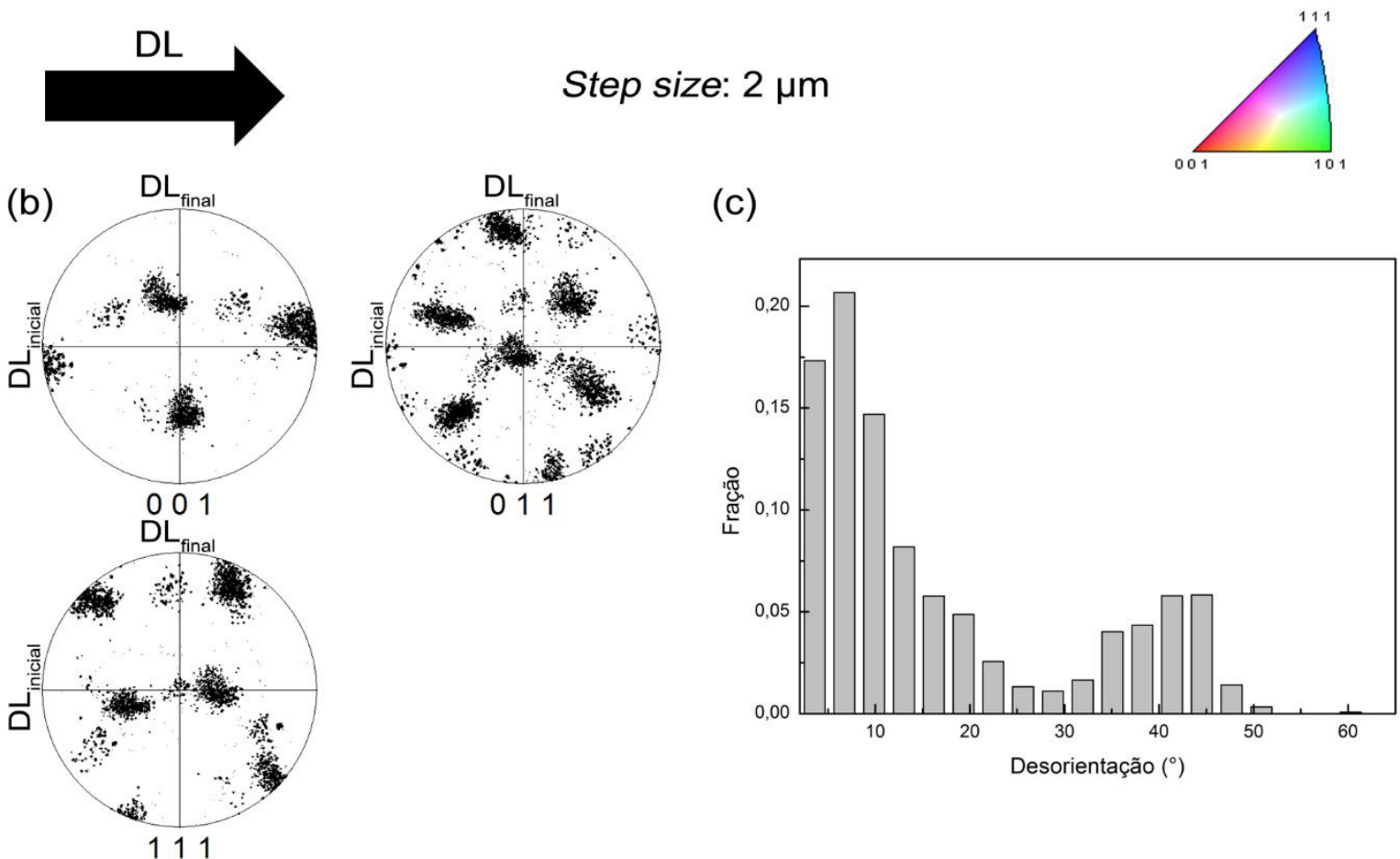

Fonte: a autora. 
Figura 5.39 - Mapeamento de orientação via EBSD da amostra C-LC-1200: (a) mapeamento de orientações; (b) figuras de polo discretas; (c) distribuição de desorientações.

(a)
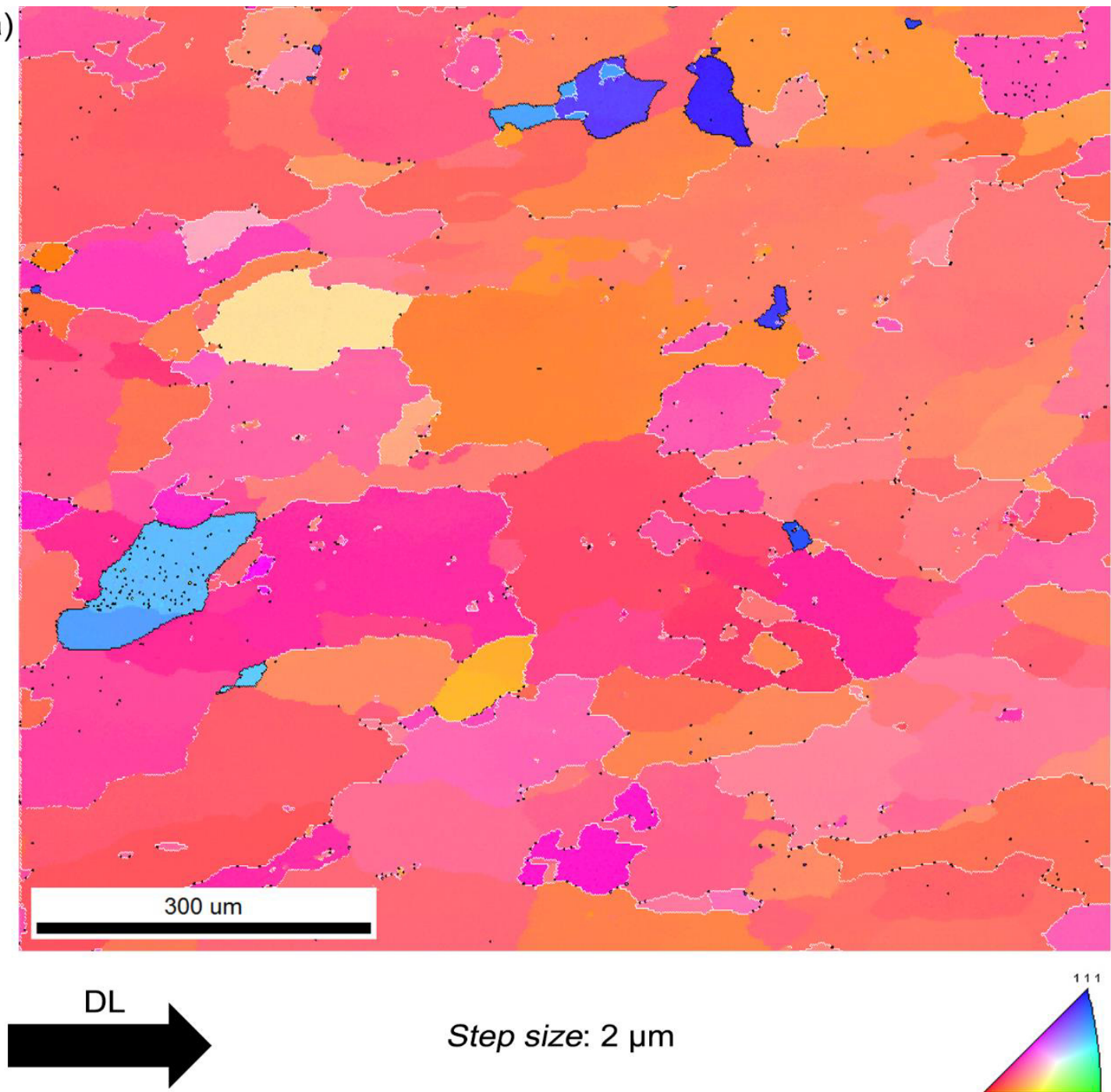

Step size: $2 \mu \mathrm{m}$

(b)
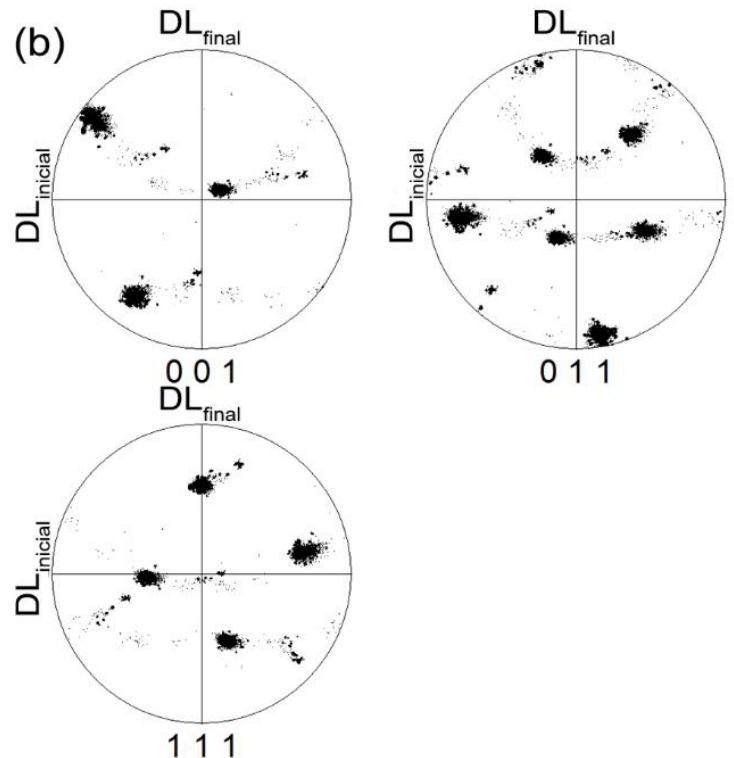

(c)

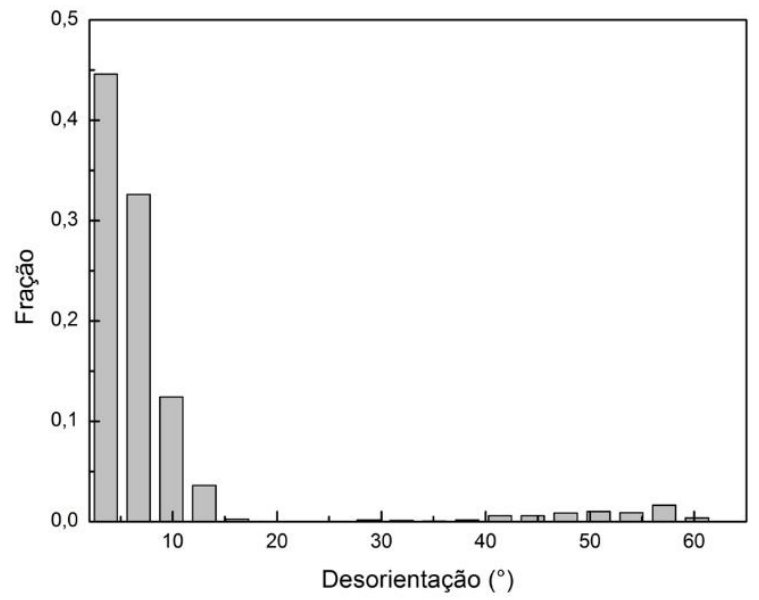

Fonte: a autora. 
Figura 5.40 - Mapeamento de orientação via EBSD da amostra E-LC-1200: (a) mapeamento de orientações; (b) figuras de polo discretas; (c) distribuição de desorientações.

(a)
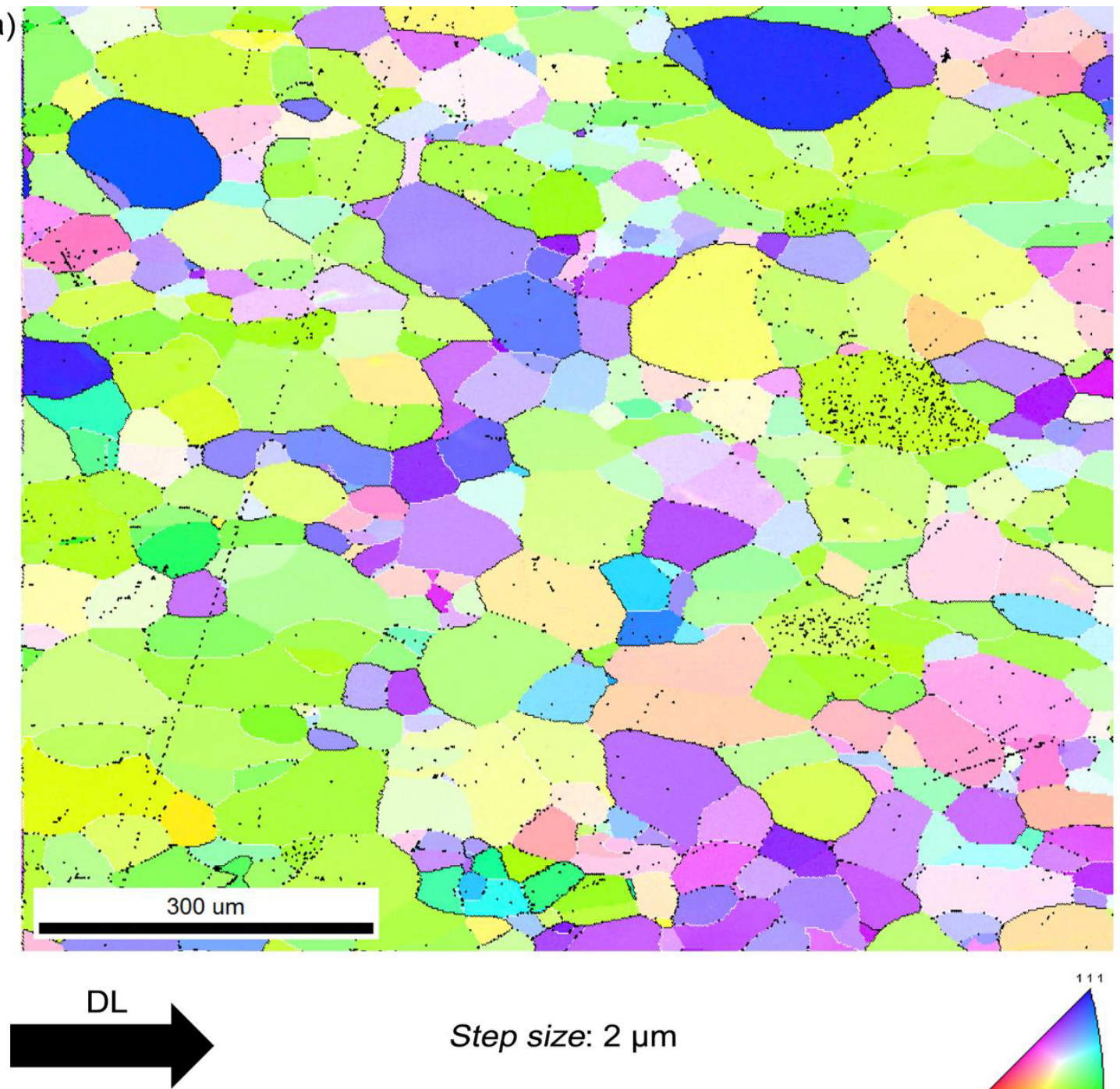

Step size: $2 \mu \mathrm{m}$
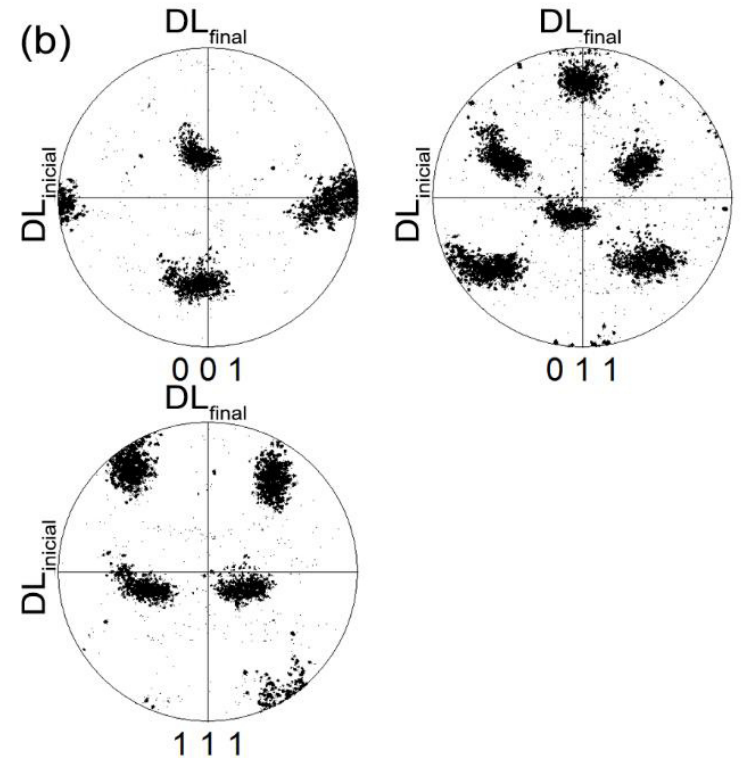

(c)
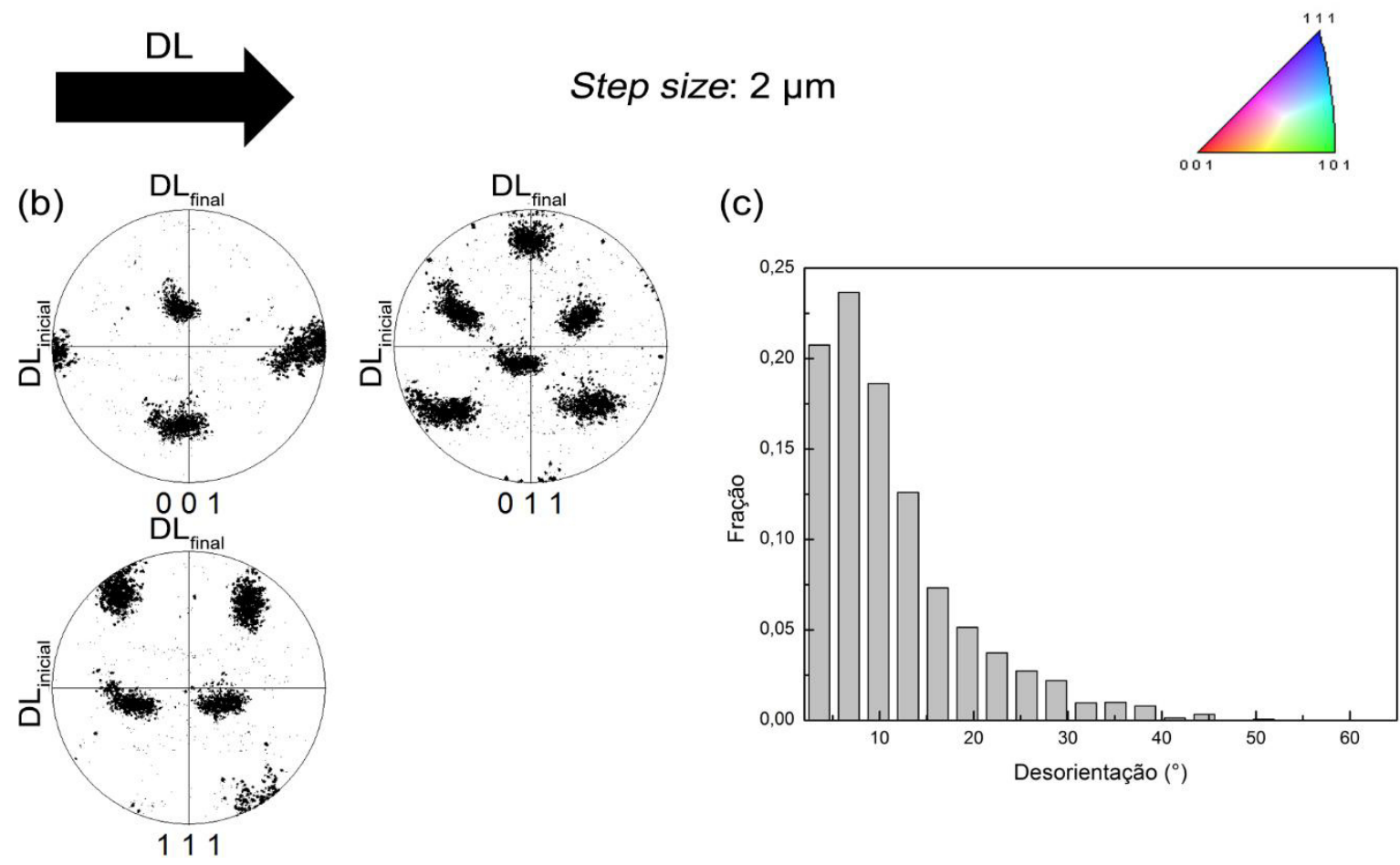

Fonte: a autora. 


\subsection{EBSD em 3D}

A amostra escolhida para este estudo foi a E-LC-800, que se fragmentou em várias bandas de deformação quase paralelas à $D L$ antes da rotação de $90^{\circ}$. A nucleação da recristalização ocorreu preferencialmente ao longo das bandas de transição como mostra a Figura 5.41 (a). Note que os grãos recristalizados tendem a formar protrusões alongadas com razão de aspecto (comprimento sobre largura) maior que 10. A maioria delas é paralela à DL final indicando que esse segmento do contorno se move mais rapidamente nesse sentido. Parte da amostra marcada na Figura 5.41 (a) foi selecionada para fazer o mapeamento de orientações mostrado na Figura 5.41 (b). A matriz recuperada, bem como as protrusões horizontais, tem uma orientação bastante uniforme. Como é mostrado na Figura 5.41 (c), ambos grupos podem ser identificados na figura de polo \{001\}. A forte textura recristalizada pode ser bem compreendida pelo fato da matriz recuperada ser muito uniforme e os núcleos de recristalização possuírem uma desorientação muito semelhante em relação à matriz. Vale a pena mencionar que os grãos identificados como 1 e 2 (Figura 5.41 (b)) mostram orientação distinta e também têm direções de migração de contorno de grão diferentes. A Figura 5.42 mostra o mapa de KAM e o mapa de qualidade de imagem (IQ, do inglês image quality) da região onde a reconstrução 3D foi realizada. Após a recuperação, a matriz mostra uma subestrutura formada por subgrãos (Figura 5.42 (b)) e elevada densidade de discordâncias (Figura 5.42 (a)). Dois núcleos recristalizados, marcados por setas pretas na Figura 5.42 (a), são encontrados na matriz recuperada apresentam morfologia quase equiaxial. Além disso, os perfis de desorientação ponto-a-ponto paralelos à DL final (Figura 5.42 (c)) e à DL inicial (Figura 5.42 (d)) mostram comportamento similar e a desorientação em ambas as direções é menor que $10^{\circ}$. Portanto, o crescimento anisotrópico desses grãos não pode ser atribuído apenas às heterogeneidades locais de energia armazenada, como reivindicado por muitos autores. Outras variáveis também desempenham um papel no fenômeno. Uma explicação provável é a orientação do plano de contorno dos grãos e seu caráter $(63,65)$. A fim de verificar isto foi realizado o mapeamento de EBSD em 3D na região destacada pelo retângulo tracejado na Figura 5.41 (b). 
Figura 5.41 - Amostra E-LC-800: (a) micrografia da amostra (ECCl); (b) mapeamento de orientações; (c) figura de polo $\{001\}$ da área mapeada.

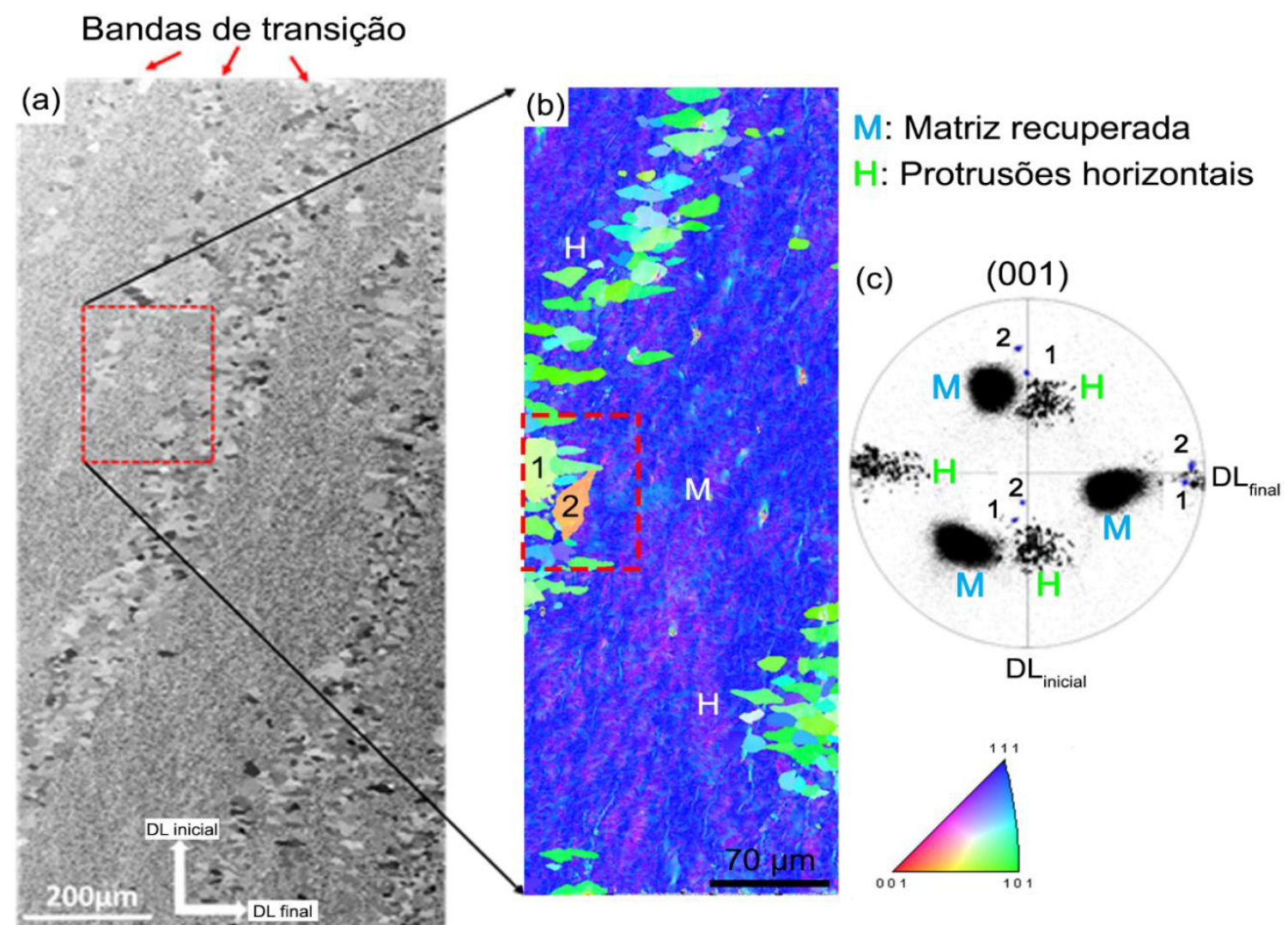

Fonte: a autora.

Figura 5.42 - Região selecionada para reconstrução em 3D: (a) mapa de KAM; (b) mapa de QI das regiões selecionadas para reconstrução 3D; (c) perfil de desorientação ponto-a-ponto ao longo da DL final; (d) perfil de desorientação ponto-a-ponto ao longo da DL inicial. Os contornos de alto ângulo são indicados em vermelho em (a) e (b). Os contornos de baixo ângulo são indicados em azul e verde, para desorientação entre $5^{\circ}$ e $15^{\circ}$, e abaixo de $5^{\circ}$, respectivamente.
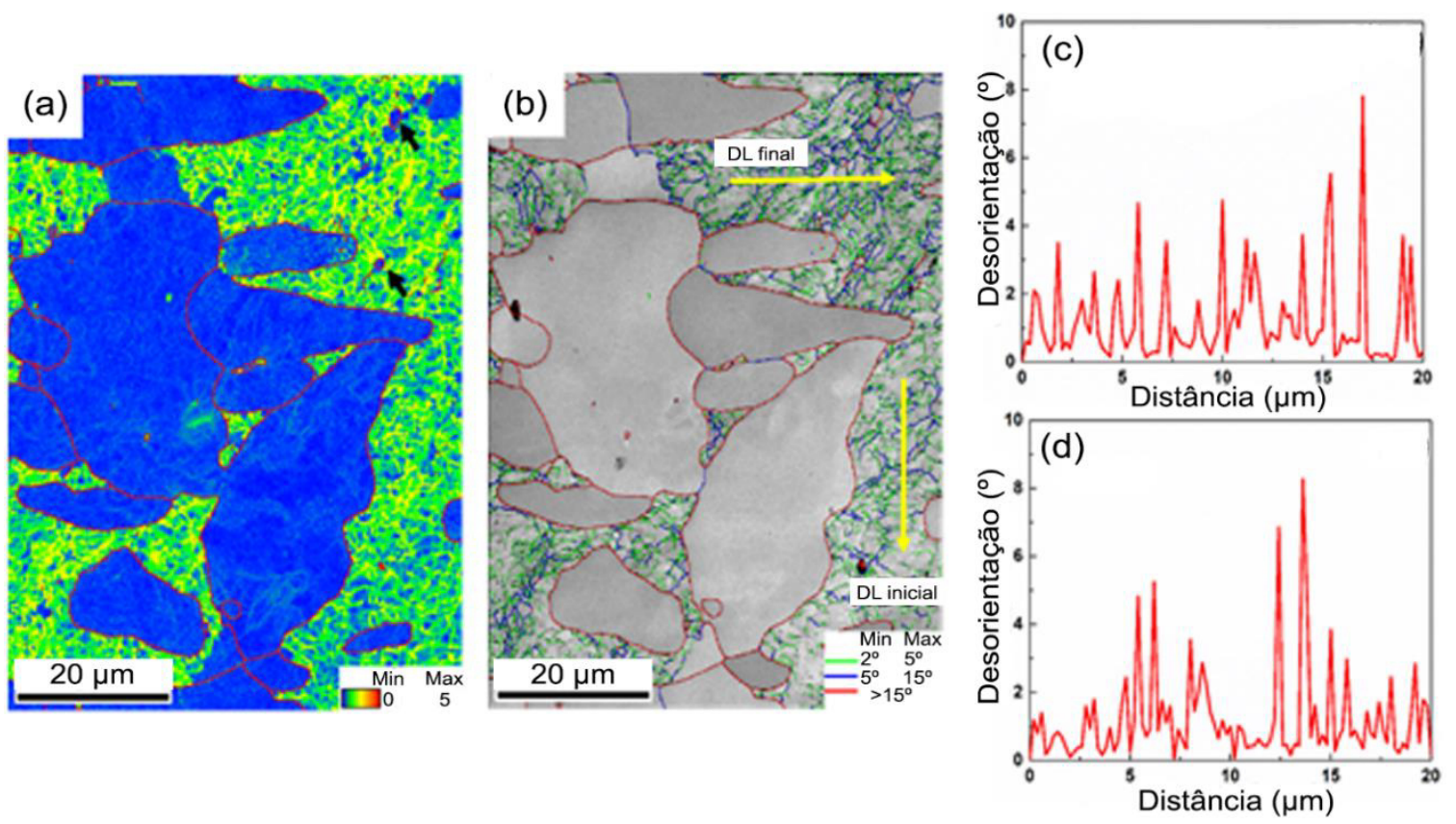

Fonte: a autora. 
A Figura 5.43 (a) mostra a reconstrução 3D da região selecionada. Três grãos individuais denominados P1, P2 e P3 foram escolhidos e as morfologias de seus contornos de grão serão discutidas na sequência em detalhes. Observe que os grãos P1 e P3 têm orientação semelhante, bem como a direção da migração de contorno, enquanto que o grão P2 mostra condições diferentes. Note que a ponta da protrusão, onde o contorno se move mais rápido, ocupa apenas uma pequena porção da área total do contorno de grão. Para mostrar claramente a morfologia e a distribuição do plano do contorno de grão nesta área, uma área menor com uma ponta de protrusão (realçada pelo retângulo tracejado vermelho) foi cortada da reconstrução 3D e é mostrada na Figura 5.43 (b). Sua morfologia 3D e a correspondente distribuição normal do contornos de grão em coordenadas cristalográficas exibidas no mapeamento de orientações são mostradas na Figura 5.43 (c) e (d), respectivamente. A variação das cores da Figura 5.43 (c) e a grande distribuição do contorno de grão normal na Figura 5.43 (d) revelam ambas uma alta rugosidade na ponta da protrusão, o que leva a uma alta taxa de migração, como relatado na referência (61).

Figura 5.43 - (a) reconstrução 3D do volume medido exibido pelo mapeamento de orientações com a DN como direção de referência; (b) reconstrução 3D de locais que contém a ponta de uma protrusão; (c) morfologia 3D da ponta da protrusão. A cor indica a direção normal do contorno de grão de acordo com a escala de cores. Os contornos de grão são gradeados em triângulos de superfície; (d) mostra a distribuição normal do plano dos contornos de grãos desses triângulos do mapeamento de orientações. N: o número de contornos de grãos total normal (igual à quantidade de triângulos de superfície em malha).
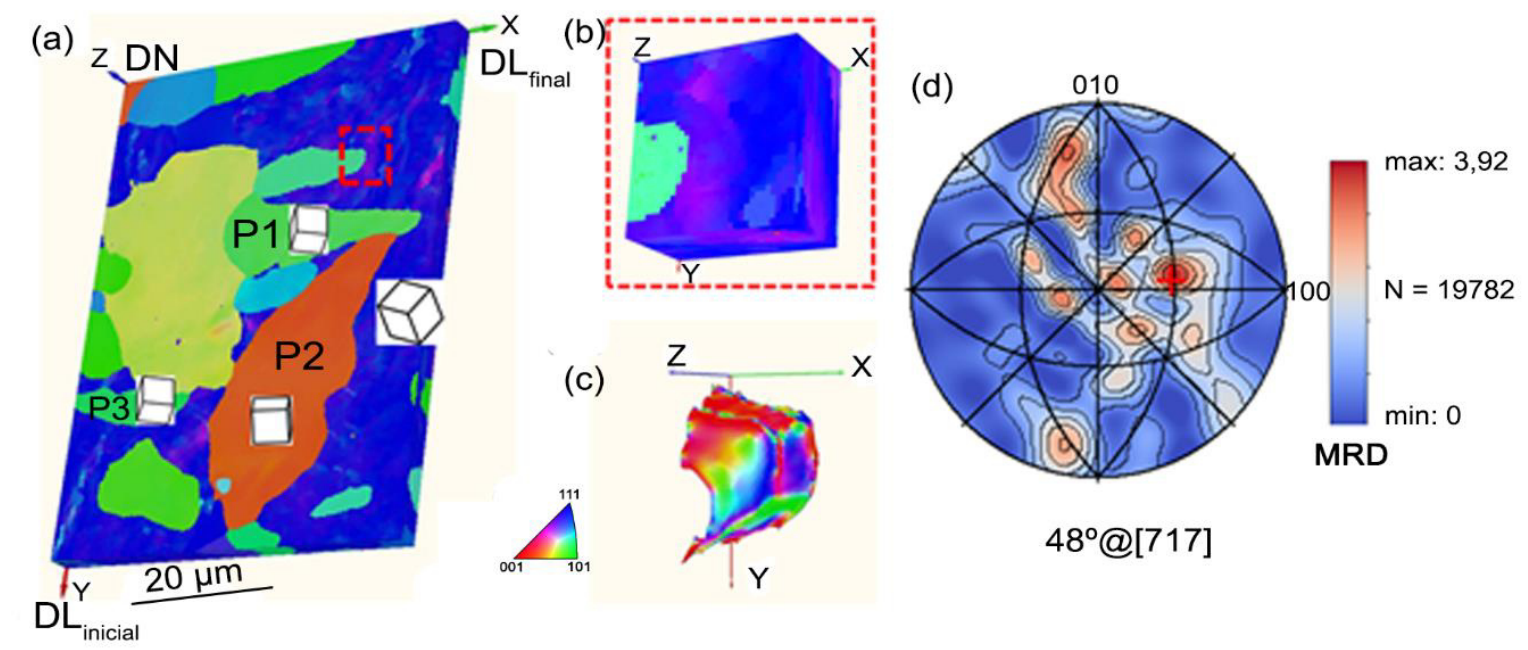

48@[717]

Fonte: a autora. 
As superfícies completas dos contornos de grãos dos grãos selecionados (P1, P2 e P3) são mostradas nas Figura 5.44 (a), (d) e (g), respectivamente. Note que para cada contorno de grão, a normal à superfície do contorno de grão dos dois grãos relacionados geralmente não é a mesma. No caso do grão P1, o plano do seu contorno de grão mostra principalmente a cor vermelha (destacada pelas setas vermelhas na parte superior da Figura 5.44 (b)) enquanto que a da matriz recuperada relacionada mostra a cor verde (destacada pelas setas verdes na parte inferior da Figura 5.44 (b)). Nota-se que a normal do contorno da ponta da protrusão é diferente daqueles dos demais segmentos de contornos (aqueles que não formam a protrusão, que serão chamados de contornos da lateral do grão). Como mencionado anteriormente, os segmentos da lateral do grão (com menor velocidade de migração) sempre ocupam a maior parte das superfícies dos contornos de grão. Portanto, as figuras de polo na Figura 5.44 ((c), (f) e (i)) mostram principalmente as informações dos segmentos das laterais do grão.

Em comparação com a ponta da protrusão, os segmentos da lateral mostram uma cor muito uniforme, indicando superfícies planas e lisas. A normal ao contorno de grão é determinada pela distribuição máxima em múltiplos da distribuição aleatória (MRD, do inglês multiples of the random distribution). Observa-se que o segmento do contorno de grão entre o grão P1 e a matriz mostra um par $(\overline{1} 03)_{P 1} /(\overline{1} 34)_{M}$. Similarmente, para o grão P2 o par $(341)_{P 2} /(\overline{3} \overline{1} 0)_{M}$ é encontrado. Para o grão P3, são encontrados dois pares, sendo eles, $(\overline{1} 03)_{P 3} /(\overline{1} 34)_{M}$ e $(301)_{P 3} /(431)_{M}$. Esta situação, isto é, a formação de pares da família $\{013\} /\{134\}$, também se aplica a outras protrusões na região de reconstrução $3 D$ selecionada, bem como numa área de EBSD em 3D adicional. Isto sugere que a preferência para formar pares $\{013\} /\{134\}$ é um fenômeno universal no caso estudado. O motivo pelo qual eles preferem pares $\{013\} /\{134\}$ pares ainda não é tão claro. Uma possível razão pode ser que contornos de grão com pares $\{013\} /\{134\}$ tenham a energia mais baixa dentro de um certo intervalo de desorientação. Já foi reportado na literatura (94) em um material com estrutura cúbica de faces centradas, contornos de grão com maior fator de empacotamento atômico (FEA) mostram menor energia de contorno de grão. Um mecanismo semelhante também pode ser usado para materiais com estrutura cúbica de corpo centrado, como é o presente caso. Note que planos da família \{134\} são próximos de $\{011\}$, que tem a maior FEA em metais cúbicos de corpo centrado. 
Se esta hipótese é admitida, contornos de grãos com pares $\{013\} /\{134\}$ têm energia superficial mais baixa e favorecem o crescimento anisotrópico de grãos recristalizados levando à formação de protrusões. Cercado por uma matriz recuperada bastante uniforme, os núcleos equiaxiais de recristalização se formam nas bandas de transição. A energia armazenada na matriz recuperada fornece a pressão motriz para o crescimento de núcleos recristalizados. Ao mesmo tempo, a área de superfície dos contornos de grão e a sua energia aumentam. O crescimento do núcleo só pode ocorrer se a pressão motriz consumida (energia armazenada) for maior que o aumento da energia do contorno de grão. Para minimizar a energia dos contornos de grão, os grãos recristalizados tendem a migrar ao longo das direções que formam pares $\{013\} /\{134\}$. O desvio dessas direções perderá os pares $\{013\} /\{134\}$ (a menos que eles formem outro par $\{013\} /\{134\}$ ) e aumentará significativamente a energia do contorno de grão. Consequentemente, o crescimento anisotrópico de grãos recristalizados está relacionado à anisotropia de energia do contorno de grão. Para uma relação de desorientação definida entre grão recristalizado e matriz, a direção de migração preferencial é definida (ilustrada na Figura 5.45). Portanto, a forte textura recristalizada leva ao fato de que a maioria das protrusões é paralela à DL final. 
Figura 5.44 - (a) morfologia 3D do grão P1; (b) morfologia 3D dos contornos de grão entre matriz e o grão P1; (c) distribuição do contorno de grão; (d) morfologia 3D do grão P2; (e) morfologia 3D dos contornos de grão entre matriz e o grão P2; (f) distribuição do contorno de grão; (g) morfologia 3D do grão P3; (b) morfologia 3D dos contornos de grão entre matriz e o grão P3; (c) distribuição do contorno de grão. Nas figuras (a), (b), (d), (e), (g) e (h) a cor indica a normal ao contorno tanto no grão recristalizado como na matriz recuperada segundo a escala de cor. $\mathrm{N}$ : o número total de contornos de grão normal (igual à quantidade de triângulos de superfície em malha).

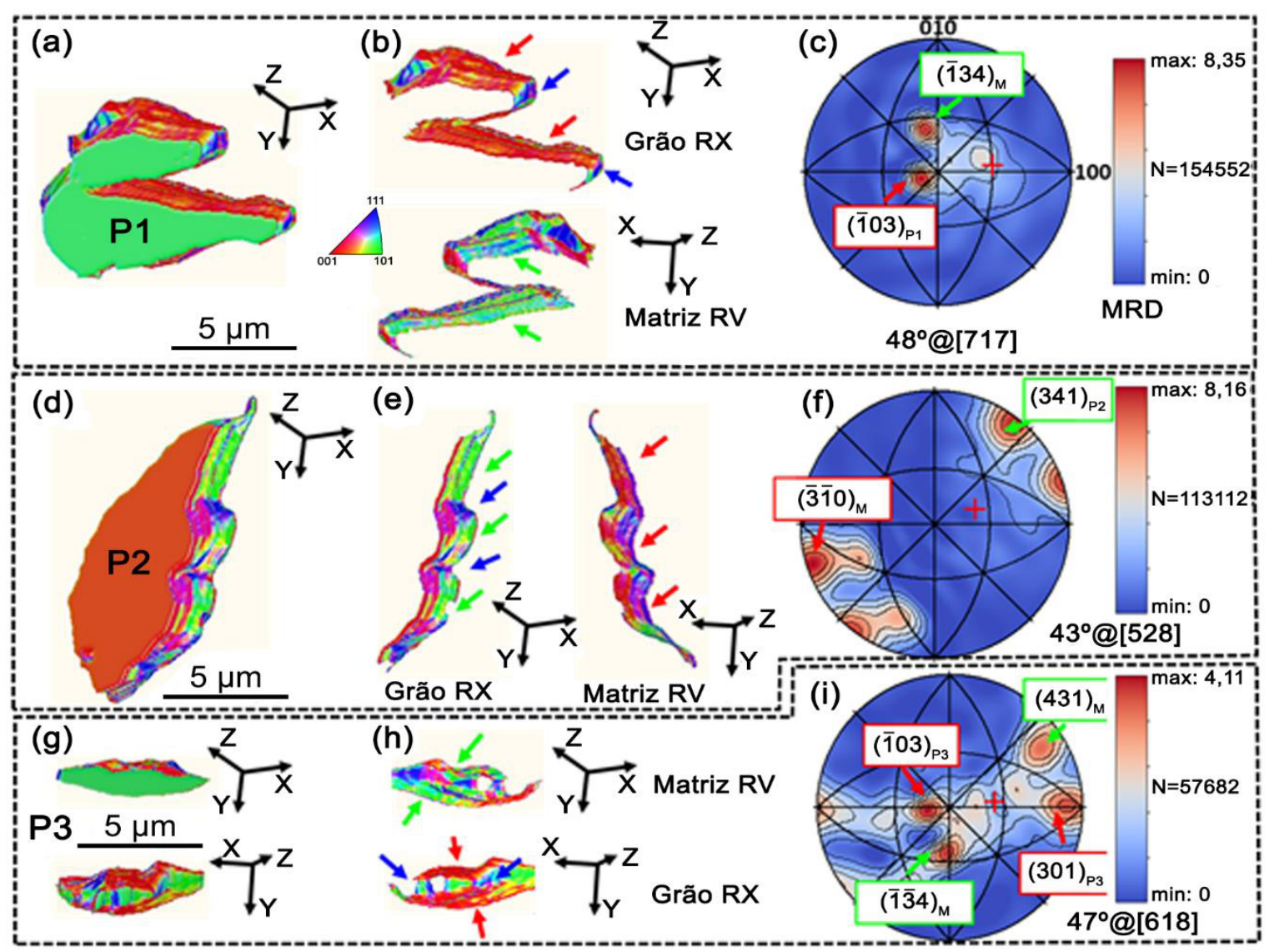

Fonte: a autora. 
Figura 5.45 - (a) primeira camada do mapa de EBSD em 3D; (b) e (c) listam a distribuição dos polos $\{013\}$ e $\{011\}$ para os grãos P1 e P2, respectivamente. Estas figuras de polo são plotadas com o auxílio de um software in house TOCA no MPIE. Todos os possíveis pares $\{013\} /\{011\}$ são destacados por círculos vermelhos com um ângulo de desvio de cerca de $10^{\circ}$. As linhas tracejadas pretas e azuis indicam o possível traço dos contornos de grão que formam os pares $\{013\} /\{134\}$.

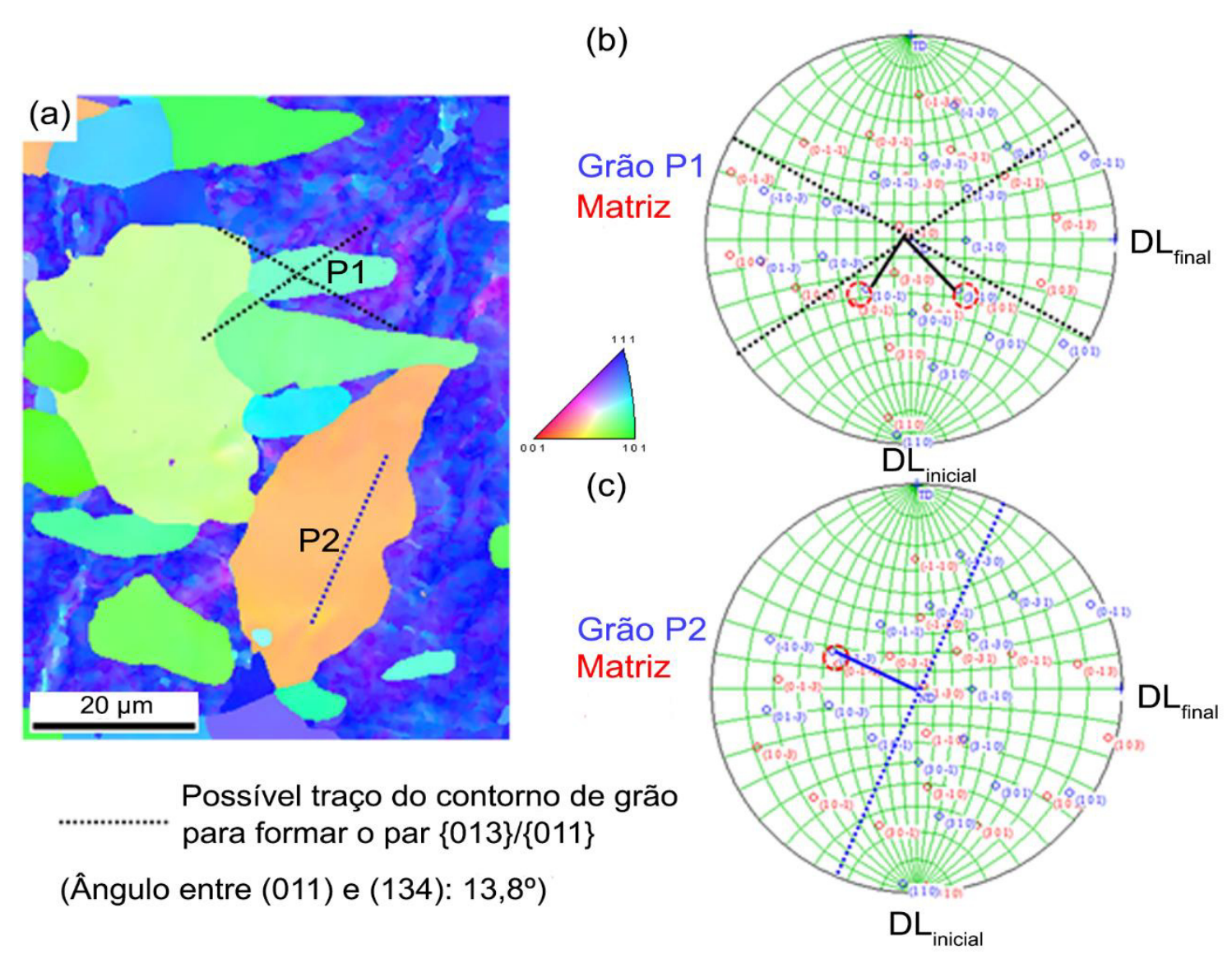

Fonte: a autora. 


\section{CONCLUSÕES}

Com base nos resultados obtidos nesta Tese, as seguintes conclusões podem ser obtidas:

a) A orientação inicial do grão tem forte influência no comportamento frente à deformação do material e posterior recristalização. Algumas orientações $(B, C$ e D) mostraram-se bastante resistentes à recristalização nas temperaturas utilizadas nesta Tese, pois possuem orientações mais estáveis, armazenando menos energia na deformação, sendo mais propensas à pronunciada recuperação. Os grãos $\mathrm{B}$ e $\mathrm{D}$ não recristalizaram mesmo quando recozidos em $1200^{\circ} \mathrm{C}$.

b) O início da recristalização ocorre de forma predominante nas bandas de transição que subdividem os grãos grosseiros durante a laminação a frio, no caso dos grãos que se fragmentaram via formação de bandas de deformação.

c) A formação de protrusões é observada no início da recristalização nas amostras A-LC e E-LC recozidos em $800^{\circ} \mathrm{C}$. Pela falta de núcleos no interior das bandas, essas protrusões se desenvolvem e atingem elevadas razões de aspecto levando à formação de estruturas recristalizadas bandeadas com tamanho e morfologia distintas.

d) A laminação cruzada mostrou-se um método bastante confiável e reprodutivo para a produção de protrusões na recristalização. A quantidade, a forma e o tamanho das protrusões (razão de aspecto) variam localmente para cada condição (orientação e temperatura de recozimento) e também numa mesma amostra.

e) Não foram encontradas evidências que comprovem de forma inequívoca a relação entre a formação de protrusões e a presença de contornos especiais. Os mapeamentos de EBSD de várias regiões também não evidenciaram a presença de contornos com elevada desorientação à frente das protrusões, tais como microbandas.

f) O crescimento das protrusões é fortemente anisotrópico, implicando no surgimento de grãos alongados com elevada razão de aspecto. Ligeiras alterações na migração lateral das protrusões são observadas quando estes segmentos interagem com os contornos de baixo ângulo. 
g) O recozimento em $1200^{\circ} \mathrm{C}$ promoveu a recristalização total das amostras A-LC e E-LC, as quais não mostram sinais das protrusões na microestrutura indicando o seu caráter transitório.

h) Os resultados dos mapeamentos de EBSD em 3D mostram a importância da inclinação dos planos dos contornos que migram em direção à matriz recuperada na formação das protrusões primárias com elevada razão de aspecto. No exemplo estudado, contornos de grãos com pares $\{013\} /\{134\}$ entre o contorno de grão da região da protrusão e a matriz recuperada são os encontrados em maior frequência. Provavelmente esse par possui menor energia interfacial, facilitando o crescimento anisotrópico do grão e a consequente formação de protrusões. 


\section{REFERÊNCIAS}

(1) LINS, J. F.C. Estudo da recuperação e da recristalização do nióbio com microestrutura oligocristalina laminado a frio. 2002, 210 f. Dissertação (Mestrado) - Faculdade de Engenharia Química de Lorena, Lorena, 2002.

(2) SANDIM, H. R. Z. Preparação de ligas de $\mathrm{Nb}-\mathrm{TiO}_{2}$ por metalurgia do pó e sua caracterização microestrutural. 1996, 238 f. Tese (Doutorado) Escola Politécnica da Universidade de São Paulo, São Paulo, 1996.

(3) LAVERICK, C. Niobium demand and superconductor applications: an overview. Journal of the Less Common Metals, v. 139, p. 107-122, April 1988.

(4) HUMPHREYS, F. J.; HATHERLY, M. Recrystallization and related annealing phenomena. 2. ed. Kidlington, Oxford: Elsevier, 2004.

(5) PADILHA, A. F.; SICILIANO Jr, F. Encruamento, recristalização, crescimento de grão e textura. 3. ed. São Paulo: Associação Brasileira de Metalurgia e Materiais, 2005.

(6) HANSEN, N.; JENSEN, D. J. Deformed metals - structure, recrystallisation and strength. Materials Science and Technology, v. 27, n. 8, p. 1229-1240, 2011.

(7) MEYERS, M. A.; CHAWLA, K. K. Mechanical behavior of materials. 2. ed. Cambridge: Cambridge University Press; 2009.

(8) DIETER, G. E. Mechanical metallurgy. 3. ed. New York: McGraw-Hill, 1988.

(9) KUHLMANN-WILSDORF, D. Questions you always wanted (or should have wanted) to ask about work hardening. Materials Research Innovations, v. 1, n. 4, p. 265-297, 1998.

(10) SMALLMAN, R. E.; BISHOP, R. J. Modern physical metallurgy and materials engineering. 6. ed. Oxford: Butterworth-Heinemann, 1999. 
(11) SANDIM, H. R. Z. Heterogeneidades de deformação: uma visão microscópica. In: TSCHIPTSCHIN, A.; PADILHA, A. F.; SCHOEN, C. G.; LANDGRAF, F. J. G.; GOLDENSTEIN, H.; FALLEIROS, I. G. S.; LIMA, N. B. (Org.) Textura e relações de orientação: deformação plástica, recristalização, crescimento de grão. 1. ed. São Paulo: Editora da Universidade de São Paulo, 2001. p. 11-22.

(12) HUGHES, D. A.; HANSEN, N. High angle boundaries formed by grain subdivision mechanisms. Acta Materialia, v. 45. n. 9, p. 3871-3886, 1997.

(13) DOHERTY, R. D. et al. Current issues in recrystallization: a review. Materials Science and Engineering: A, v. 238, n. 2, p. 219-274, 1997.

(14) HANSEN, N. Deformation microstructures. Scripta Metallurgica et Materialia, v. 27, n. 11, p. 1447-1452, 1992.

(15) SANDIM, H. R. Z.; RAABE, D. EBSD study of grain subdivision of a Goss grain in coarse-grained cold-rolled niobium. Scripta Materialia, v. 53, n. 2, p. 207-212, 2005.

(16) SANDIM, H. R. Z. et al. Recrystallization behavior of a cold-rolled niobium bicrystal. Materials Science and Engineering A, v. 354, n. 1-2, p. 217-228, 2003.

(17) SANDIM, H. R. Z.; MCQUEEN, H. J.; BLUM, W. Microstructure of cold swaged tantalum at large strains. Scripta Materialia, v. 42, n. 2, p. 151-156, 1999.

(18) LEE, C. S.; DUGGAN, B. J.; SMALLMAN, R. E. A theory of deformation banding in cold rolling. Acta Metallurgica et Materialia, v. 41, n. 8, p. 22652270, 1993.

(19) KUHLMANN-WILSDORF, D. Overview No. 131: "regular" deformation bands (DBs) and the LEDS hypothesis. Acta Materialia, v. 47, n. 6, p. 1697-1712, 1999. 
(20) STÜWE, H. P.; PADILHA A. F.; SICILIANO Jr., F. Competition between recovery and recrystallization. Materials Science and Engineering A, v. 333, n. 1-2, p. 361-367, 2002.

(21) HUMPHREYS, F. J. Nucleation in recrystallization. Materials Science Forum, v. 467-470, p. 107-116, 2004.

(22) RIOS, P. R. et al. Nucleation and growth during recrystallization. Materials Research, v. 8, n. 3, p. 225-238, 2005.

(23) ROLLETT, A. D. et al. Grain boundary mobility - a brief review. Zeitschrift für Metallkunde, v. 95, n. 4, p. 226-229, 2004.

(24) PADILHA A. F.; SICILIANO Jr., F. Crescimento das regiões recristalizadas. In: TSCHIPTSCHIN, A.; PADILHA, A. F.; SCHOEN, C. G.; LANDGRAF, F. J. G.; GOLDENSTEIN, H.; FALLEIROS, I. G. S.; LIMA, N. B. (Org.) Textura e relações de orientação: deformação plástica, recristalização, crescimento de grão. 1. ed. São Paulo: Editora da Universidade de São Paulo, 2001. p. 49-58.

(25) GOTTSTEIN, G. et al. Grain boundary migration: misorientation dependence. Current Opinion in Solid State and Materials Science, v. 5, n. 1, p. 9-14, 2001.

(26) HUANG, Y.; HUMPHREYS, F. J. Measurements of grain boundary mobility during recrystallization of a single-phase aluminium alloy. Acta Materialia, v. 47, n. 7, p. 2259-2268, 1999.

(27) LIEBMAN, B.; LÜCKE, K.; MASING G. Untersuchung über die orientierungsabhängigkeit der wachstumsgeschwindigkeit bei der primären rekristallisation von aluminium-einkristallen. Zeitschrift für Metallkunde, v. 47, n. 2, p. 57-63, 1956.

(28) RANDLE, V. "Special" boundaries and grain boundary plane engineering. Scripta Materialia, v. 54, n. 6, p. 1011-1015, 2006. 
(29) GOTTSTEIN, G.; SHVINDLERMAN, L. S. On the orientation dependence of grain boundary migration. Scripta Metallurgica et Materialia, v. 27, p. 15151520, 1992.

(30) AUST, K. T.; RUTTER, J. W. Grain boundary migration in high-purity lead and dilute lead-tin alloys. Transactions of the American Institute of Mining and Metallurgical Engineers, v. 215, n. 1, p. 119-127, 1959.

(31) AUST, K. T.; RUTTER, J. W. Temperature dependence of grain migration in high-purity lead containing small additions of tin. Transactions of the American Institute of Mining and Metallurgical Engineers, v. 215, n. 5, p. 820-831, 1959.

(32) JENSEN, D. J.; SCHMIDT, S. Time evolution in 3D metal microstructures recrystallization. Materials Transactions, v. 50, n. 7, p. 1655-1659, 2009.

(33) HUANG, X.; WINTHER, G. Dislocation structures. Part I. Grain orientation dependence. Philosophical Magazine, v. 87, n. 33, p. 5189-5214, 2007.

(34) MOELANS, N. et al. Phase-field simulation study of the migration of recrystallization boundaries. Physical Review B, v. 88, n. 5, p. 1-10, 2013.

(35) MOELANS, N. et al. A phase-field simulation study of irregular grain boundary migration during recrystallization. IOP Conference Series: Materials Science and Engineering, v. 89, n. 1, p. 1-8, 2015.

(36) BECK P. A.; SPERRY, P. R.; HU, H. The orientation dependence of the rate of grain boundary migration. Journal of Applied Physics, v. 21, n. 5, p. 420425, 1950.

(37) BECK, P. A.; SPERRY, P. R. Strain induced grain boundary migration in high purity aluminum. Journal of Applied Physics, v. 21, n. 2, p. 150-152, 1950.

(38) BELLIER, S. P.; DOHERTY R. D.; The structure of deformed aluminium and its recrystallization - investigations with transmission Kossel diffraction. Acta Metallurgica, v. 25, n. 5, p. 521-538, 1977. 
(39) KASSNER, M. E.; MCMAHON, M. E. The dislocation microstructure of aluminum deformed to very large steady-state creep strains. Metallurgical Transactions A, v. 18, n. 6, p. 835-346, 1987.

(40) DRURY, M. R.; HUMPHREYS, F. J. The development of microstructure in Al$5 \% \mathrm{Mg}$ during high temperature deformation. Acta Metallurgica, v. 34, n. 11, p. 2259-2271, 1986.

(41) KONOPLEVA, E. V.; MCQUEEN H. J.; EVANGELISTA, E. Serrated grain boundaries in hot-worked aluminum alloys at high strains. Materials Characterization, v. 34, n. 4, p. 251-264, 1995.

(42) BELYAKOV, A.; MIURA, H.; SAKAI, T. Dynamic recrystallization under warm deformation of polycrystalline copper. ISIJ International, v. 38, n. 6, p. 595601, 1998.

(43) WUSATOWSKA-SARNEK, A. M.; MIURA, H.; SAKAI, T. Nucleation and microtexture development under dynamic recrystallization of copper. Materials Science and Engineering A, v. 323, n. 1-2, p. 177-186, 2002.

(44) LENS, A.; MAURICE, C.; DRIVER, J. H. Grain boundary mobilities during recrystallization of Al-Mn alloys as measured by in situ annealing experiments. Materials Science and Engineering A, v. 403, n. 1-2, p. 144-153, 2005.

(45) MARTORANO, M. A. et al. Observations of grain boundary protrusions in static recrystallization of high-purity bcc metals. Scripta Materialia, v. 56, n. 10, p. 903-906, 2007.

(46) SCHMIDT, S. et al. Watching the growth of bulk grains during recrystallization of deformed metals. Science, v. 305, n. 5681, p. 229-232, 2004.

(47) JENSEN, D. J.; ROWENHORST, D.J.; SCHMIDT, S. Misorientation aspects of growth during recrystallization. Materials Science Forum, v. 558-559, p. 85-92, 2007. 
(48) BOXEL, S. V. et al. Direct observation of grain boundary migration during recrystallization within the bulk of a moderately deformed aluminium single crystal. Materials Transactions, v. 55, n. 1, p. 128-136, 2014.

(49) LUDWIG, W. et al. New opportunities for 3D materials science of polycrystalline materials at the micrometre lengthscale by combined use of $\mathrm{X}$ ray diffraction and $X$-ray imaging. Materials Science and Engineering $A, v$. 524, n. 1-2, p. 69-76, 2009.

(50) ZHANG, Y.; GODFREY, A.; JENSEN, D. J. Local boundary migration during recrystallization in pure aluminium. Scripta Materialia, v. 64, n. 4, p. 331-334, 2011.

(51) JENSEN, D. J. et al. Importance of local structural variations on recrystallization. Materials Science Forum, v. 753, p. 37-41, 2013.

(52) ZHANG, Y.; JENSEN, D. J.; GODFREY, A. Boundary migration during recrystallization of heavily deformed pure nickel. Materials Science Forum, v. 715-716, p. 329-332, 2012.

(53) MARTORANO, M. A.; FORTES, M. A.; PADILHA, A. F. The growth of protrusions at the boundary of a recrystallized grain. Acta Materialia, v. 54, n. 10, p. 2769-2776, 2006.

(54) GODIKSEN, R. B. et al. Simulations of boundary migration during recrystallization using molecular dynamics. Acta Materialia, v. 55, n. 18, p. 6383-6391, 2007.

(55) ZHANG, Y.; GODFREY, A.; JENSEN, D. J. Measurements of the curvature of protrusions/retrusions on migrating recrystallization boundaries. Computers, Materials \& Continua, v. 14, n. 3, p. 197-207, 2009.

(56) ZHANG, Y.; GODFREY, A.; JENSEN, D. J. In-situ investigation of local boundary migration during recrystallization. Metallurgical and Materials Transactions A, v. 45, n. 6, p. 2899-2905, 2014. 
(57) ZHANG, Y. B. et al. Analysis of the growth of individual grains during recrystallization in pure nickel. Acta Materialia, v. 57, n. 9, p. 2631-2639, 2009.

(58) FAN, G. H. et al. Oriented growth during recrystallization revisited in three dimensions. Scripta Materialia, v. 72-73, p. 9-12, 2014.

(59) SUN, J. et al. Characterization of boundary roughness of two cube grains in partly recrystallized copper. IOP Conference Series: Materials Science and Engineering, v. 89, n. 1, p. 1-8, 2015.

(60) HUPALO, M. F.; SANDIM, H. R. Z. The annealing behavior of oligocrystalline tantalum deformed by cold swaging. Materials Science and Engineering A, v. 318, n. 1-2, p. 216-223, 2001.

(61) SUN, J.; ZHANG, Y. B.; JENSEN, D. J. Roughness of grain boundaries in partly recrystallized aluminum. Scripta Materialia, v. 126, p. 45-49, 2017.

(62) ZHANG, Y. B.; JENSEN, D. J. Boundary migration during recrystallization: experimental observations. IOP Conference Series: Materials Science and Engineering, v. 89, n. 1, p. 1-17, 2015.

(63) KIM, C. S.; ROLLETT, A. D.; ROHRER, G. S. Grain boundary planes: new dimensions in the grain boundary character distribution. Scripta Materialia, v. 54 , n. 6 , p. $1005-1009,2006$.

(64) MOLODOV, D. A.; SHVINDLERMAN, L. S.; GOTTSTEIN, G. Impact of grain boundary character on grain boundary kinetics. Zeitschrift für Metallkunde, v. 94, n. 10, p. 1117-1126, 2003.

(65) HOMER, E. R.; PATALA, S.; PRIEDEMAN, G. Grain boundary plane orientation fundamental zones and structure-property relationships. Scientific Reports, v. 5, n. 1, p. 1-13, 2015.

(66) HAN, J.; THOMAS, S. L.; SROLOVITZ, D. J. Grain-boundary kinetics: a unified approach. Progress in Materials Science, v. 98, p. 386-476, 2018. 
(67) SCHWARTZ, A. J. et al. Electron backscatter diffraction in materials science. Boston: Springer, 2009.

(68) ENGLER, O.; RANDLE, V. Introduction to texture analysis: macrotexture, microtexture, and orientation mapping. 2. ed. Boca Raton: CRC Press, 2010.

(69) VIANA, C. S. C.; PAULA, A. S. Texturas de deformação. In: TSCHIPTSCHIN, A.; PADILHA, A. F.; SCHOEN, C. G.; LANDGRAF, F. J. G.; GOLDENSTEIN, H.; FALLEIROS, I. G. S.; LIMA, N. B. (Org.) Textura e relações de orientação: deformação plástica, recristalização, crescimento de grão. 1. ed. São Paulo: Editora da Universidade de São Paulo, 2001. p. 23-37.

(70) HU, H. Texture of metals. Texture, v.1, n. 4, p. 233-258, 1974.

(71) GODEC, M.; JENKO, M. Presentation methods of textures measurements. Materiali un Tehnologije, v. 34, n. 6, p. 359-364, 2000.

(72) DOHERTY, R. D. Recrystallization and texture. Progress in Materials Science, v. 42, p. 39-58, 1997.

(73) RAABE, D. et al. Texture and microstructure of rolled and annealed tantalum. Materials Science and Technology, v. 10, n. 4, p. 299-305, 1994.

(74) HÖLSCHER, M.; RAABE, D.; LÜCKE, K. Rolling and recrystallization textures of BCC steels. Textures and Microstructures, v. 14, n. 100, p. 567-575, 1991.

(75) ABREU, H. F. G. et al. Texture and microstructure of cold rolled and recrystallized pure niobium. Materials Science Forum, v. 539-543, p. 34363441, 2007.

(76) ASTM INTERNATIONAL. ASTM E391-18: Standard Specification for Niobium and Niobium Alloy Ingots. West Conshohocken, 2018.

(77) GONÇALVES, M. C. Influência da laminação cruzada na cinética de recuperação do nióbio com grãos grosseiros. Projeto de Iniciação Científica, FAPESP (Processo 01/04107-7), 2001. 
(78) ASTM INTERNATIONAL. ASTM E92-16: Standard Test Methods for Vickers Hardness and Knoop Hardness of Metallic Materials. West Conshohocken, 2016.

(79) ASTM INTERNATIONAL. ASTM E384-16: Standard Test Method for Microindentation Hardness of Materials. West Conshohocken, 2016.

(80) KUHLMANN-WILSDORF, D.; HANSEN, N. Geometrically necessary, incidental and subgrain boundaries. Scripta Metallurgica et Materialia, $v$. 25, n. 7, p. 1557-1562, 1991.

(81) VANDERMEER, R. A.; SNYDER, W. B. Recovery and recrystallization in rolled tantalum single crystals. Metallurgical Transactions A, v. 10, n. 8, p. 1031-1044, 1979.

(82) KAMAYA, M. Assessment of local deformation using EBSD: quantification of accuracy of measurement and definition of local gradient. Ultramicroscopy, v. 111, n. 8, p. 1189-1199, 2011.

(83) RADHAKRISHNAN, B.; et al. Modeling the kinetics and microstructural evolution during static recrystallization - Monte Carlo simulation of recrystallization. Acta Materialia, v. 46, n. 12, p. 4415-4433, 1998.

(84) HJELEN, J.; ØRSUND, R.; NES, E. On the origin of recrystallization textures in aluminium. Acta Metallurgica et Materialia, v. 39, n. 7, p. 1377-1404, 1991.

(85) THEYSSIER, M.; DRIVER, J. Recrystallization nucleation mechanism along boundaries in hot deformed Al bicrystals. Materials Science and Engineering A, v. 272, n. 1, p. 73-82, 1999.

(86) SANDIM, H. R. Z.; et. al. Orientation effects during grain subdivision and subsequent annealing in coarse-grained tantalum. Scripta Materialia, v. 45, n. 6, p. 733-738, 2001. 
(87) SANDIM, H. R. Z.; et. al. Recrystallization of oligocrystalline tantalum deformed by cold rolling. Materials Science and Engineering A, v. 392, n. 1-2, p. 209-221, 2005.

(88) SRINIVASAN, R.; et. al. Orientation effect on recovery and recrystallization of cold rolled niobium single crystals. Materials Science and Engineering A, v. 507, n. 1-2, p. 179-189, 2009.

(89) CHENG, K. et. al. Coupled grain boundary motion in aluminium: the effect of structural multiplicity. Scientific Reports, v. 6, n. 1, p. 1-11, 2016.

(90) LIU, Y. H. et al. Strain path dependence of microstructure and annealing behavior in high purity tantalum. Materials Science and Engineering A, v. 707, p. 518-530, 2017.

(91) GURAO, N. P.; SETHURAMAN, S.; SUWAS, S. Evolution of texture and microstructure in commercially pure titanium with change in strain path during rolling. Metallurgical and Materials Transactions A, v. 44, n. 3, p. 14971507, 2013.

(92) GURAO, N. P.; SETHURAMAN, S.; SUWAS, S. Effect of strain path change on the evolution of texture and microstructure during rolling of copper and nickel. Materials Science and Engineering A, v. 528, n. 25-26, p. 77397750, 2011.

(93) HUH, M.; ENGLER, O.; RAABE, D. On the influence of cross-rolling on shear band formation and texture. Textures and Microstructures, v. 24, p. 225237, 1995.

(94) AN, D.; et al. Correlating the five-parameter grain boundary character distribution and the intergranular corrosion behaviour of a stainless steel using 3D orientation microscopy based on mechanical polishing serial sectioning. Acta Materialia, v. 156, p. 297-309, 2018. 